FÁBIO LUIZ CUBEROS

NOVO MODELO INSTITUCIONAL DO SETOR ELÉTRICO BRASILEIRO: ANÁLISE DOS MECANISMOS DE MITIGAÇÃO DE RISCOS DE MERCADO DAS DISTRIBUIDORAS

São Paulo 2008 
FÁBIO LUIZ CUBEROS

\section{NOVO MODELO INSTITUCIONAL DO SETOR ELÉTRICO BRASILEIRO: ANÁLISE DOS MECANISMOS DE MITIGAÇÃO DE RISCOS DE MERCADO DAS DISTRIBUIDORAS}

Dissertação apresentada à Escola Politécnica da Universidade de São Paulo para obtenção do título de Mestre em Engenharia Elétrica

São Paulo 2008 
FÁBIO LUIZ CUBEROS

\section{NOVO MODELO INSTITUCIONAL DO SETOR ELÉTRICO BRASILEIRO: ANÁLISE DOS MECANISMOS DE MITIGAÇÃO DE RISCOS DE MERCADO DAS DISTRIBUIDORAS}

Dissertação apresentada à Escola Politécnica da Universidade de São Paulo para obtenção do título de Mestre em Engenharia Elétrica

Área de Concentração: Sistemas de Potência

Orientador: Prof. Dr. Dorel Soares Ramos

São Paulo

2008 
Este exemplar foi revisado e alterado em relação à versão original, sob responsabilidade única do autor $\mathrm{e}$ com a anuência de seu orientador.

São Paulo, 29 de setembro de 2008.

Assinatura do autor

Assinatura do orientador

Cuberos, Fábio Luiz

Novo modelo institucional do setor elétrico brasileiro : análise dos mecanismos de mitigação de riscos de mercado das distribuidoras / F.L. Cuberos. - ed.rev. -- São Paulo, 2008.

$119 \mathrm{p}$.

Dissertação (Mestrado) - Escola Politécnica da Universidade de São Paulo. Departamento de Engenharia de Energia e Automação Elétricas.

1.Distribuição de energia elétrica 2.Energia elétrica 3.Risco 4.Mitigação I.Universidade de São Paulo. Escola Politécnica. Departamento de Engenharia de Energia e Automação Elétricas II. t. 
Aos meus pais e esposa pelos ensinamentos, compreensão, estímulo e, principalmente, Amor 


\section{AGRADECIMENTOS}

À Deus, que está à frente de todas as decisões de minha vida.

Ao meu orientador, Prof. Dr. Dorel Soares Ramos, pela orientação dedicada, pelas fundamentais contribuições e pela maneira atenciosa como conduziu este trabalho.

Aos professores da banca do exame de qualificação, professores doutores Fernando Amaral de Almeida Prado Junior e Carlos Márcio Vieira Tahan, pelas preciosas considerações.

Aos amigos da Bandeirante Energia, Ronaldo Machado de Almeida, Durval Battani, José Vanderlei Bíscaro, Guilherme Marques Faria Paula e Gustavo Marques Faria Paula, pelo estímulo no início da jornada.

Aos amigos da Câmara de Comercialização de Energia Elétrica - CCEE, Márcio Leonel, Fernando Mesquita, Fernando Mussnich, Dalmir Capetta, Edmilson Ferreira e Rodolfo Coli, pelo auxílio no desenvolvimento do trabalho.

Aos amigos e companheiros Mikio Kawai Jr., Rodrigo Sanchez de Almeida e Denilson Donizetti de Toledo, que de diversas maneiras colaboraram nas etapas desse trabalho.

Aos meus pais e familiares, por estarem sempre ao meu lado em todos os momentos de minha vida.

À minha esposa e eterna companheira Fabiana Cuberos, pelo amor e compreensão. 


\section{RESUMO}

Com a reestruturação do modelo do setor elétrico brasileiro, a partir do Projeto RE-SEB, as empresas de distribuição de energia elétrica no Brasil tiveram que se adequar às novas regras de mercado, bem como alterar a sua maneira de administrar a empresa.

Com o conceito de regulação por incentivos e competição "por mercado", e não competição "no mercado", novos mecanismos de mitigação de riscos de mercado foram introduzidos no modelo do setor elétrico, de tal forma que as empresas de distribuição de energia elétrica sejam ressarcidas de maneira justa pelo serviço prestado à sociedade.

Diante desse contexto, a gestão eficiente da empresa e, conseqüentemente, o fato de atingir as metas de desempenho pré-estabelecidas pela alta administração de cada distribuidora depende cada vez mais do conhecimento das regras de mercado por seus colaboradores, bem como da utilização dos mecanismos de mitigação de riscos de mercado das distribuidoras.

Assim, esse trabalho pretende analisar os principais mecanismos de mitigação de riscos de mercado das distribuidoras envolvidos no processo de repasse dos custos de aquisição de energia elétrica às tarifas dos consumidores finais, bem como avaliar os dispositivos previstos na regulamentação legal, inserindo um estudo de caso que analisa o portfólio de contratação de uma empresa de distribuição de energia elétrica fictícia, simulando variações nos níveis de contratação da mesma bem como no portfólio, avaliando a utilização dos mecanismos de mitigação de riscos de mercado e as alternativas simuladas, como também identificando os pontos de sucesso e os pontos a serem melhorados na gestão e contratação da distribuidora.

Palavras Chave: Mitigação de Risco. Distribuição de Energia Elétrica. Mercado de Energia Elétrica. Comercialização. 


\begin{abstract}
As the restructuring of the model of the Brazilian electric sector, with the Project RE-SEB, the electric energy distribution companies in Brazil had to adjust themselves to the new rules of the market, as well as modify their way of manage the company.
\end{abstract}

As the concept of regulation for incentives (price cap model) and competition "by market", and not competition "in the market", new mechanisms to reduce the risks of the market had been introduced in the model of the electric sector, in such a way that the electric energy distribution companies receive a fair revenue for the service delivered to the society.

In this perspective, the efficient management of the company and, consequently, the fact of reaching the goals in the performance targets established by the high administration, depends on the deep knowledge of the rules of market by its technical team, as well as the use of the mechanisms to reduce the risks of the market of the distribution utilities.

In this way, this work intends to analyze (i) the main mechanisms available to the distribution companies in order to mitigate the market risks in the process of contract energy supply and to pass-though such costs to the final consumers, as well as (ii) evaluate the rules implemented in the legal regulation framework. Furthermore, to illustrate the analysis, a case study was developed focusing the contract portfolio of a fictitious distribution company, simulating variations in the contracted energy volume as well as in the portfolio composition, evaluating the uses of the mitigation mechanisms of the market risks and solution alternatives to minimize such risks, searching for improvements that could be made in the management strategy of energy supply contracting.

Keywords: Mitigation of Risks. Electric Energy Distribution. Electric Energy Market. Commercialization. 


\section{LISTA DE ILUSTRAÇÕES}

Figura 1 - Evolução da Capacidade Instalada e Consumo................................... 10

Figura 2 - Estrutura Organizacional Novo Modelo .......................................... 21

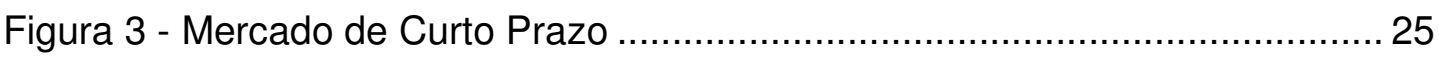

Figura 4 - Ambientes de Contratação ........................................................ 27

Figura 5 - Nível de Inadimplência por Classe de Consumo ................................... 34

Figura 6 - Redução de Contratos por Variação de Mercado (Percentuais

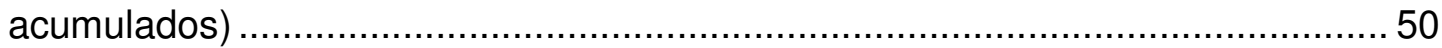

Figura 7 - Momentos de Contratação de Energia …………………….............. 54

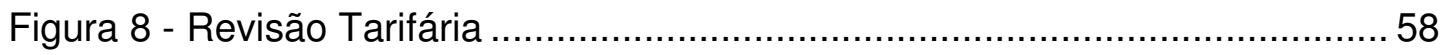

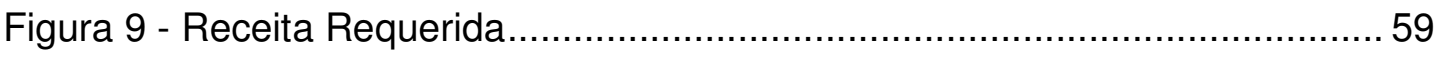

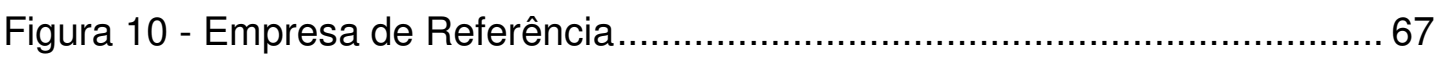

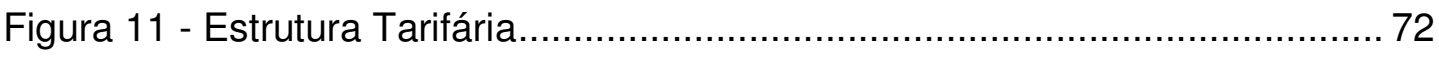

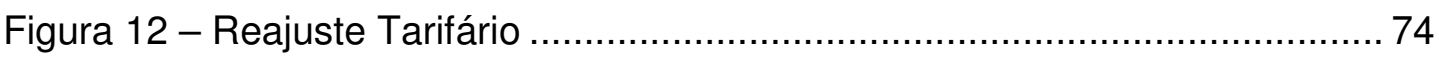

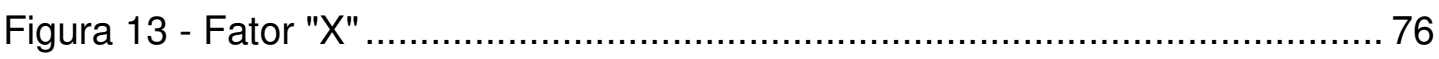

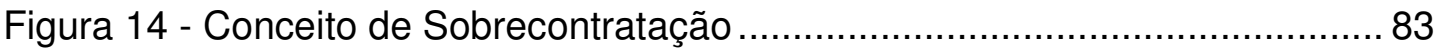

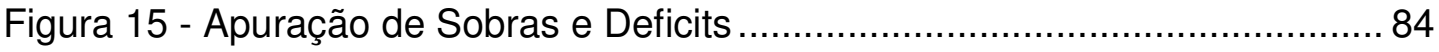

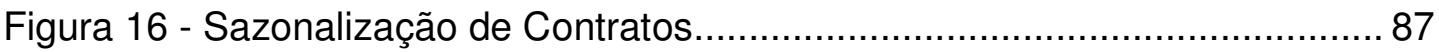

Figura 17 - Repasse da Sobrecontratação de energia ......................................... 88

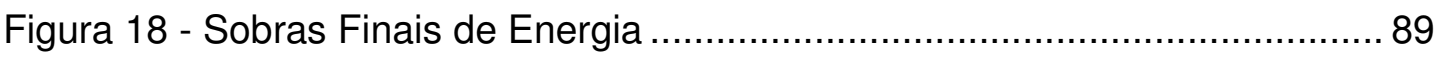

Figura 19 - Atendimento a 100\% da Carga Regulatória ........................................93

Figura 20 - Insuficiência de Cobertura de Consumo ………………………........96

Figura 21 - Níveis de Contratação das Distribuidoras ....................................... 99

Figura 22 - Comparativo entre Cenários...................................................... 110 


\section{LISTA DE TABELAS}

Tabela 1 - Classe dos Agentes de Mercado ..................................................... 26

Tabela 2 - Restrições ao Volume de Contratação de Energia .............................. 55

Tabela 3 - Restrições de Repasse Tarifário na Contratação de Energia .............. 81

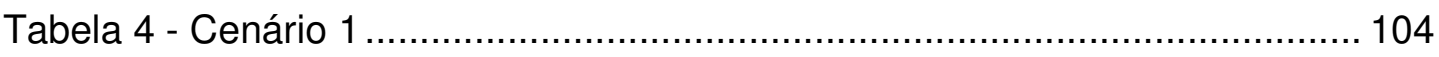

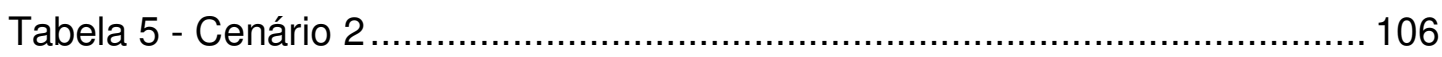

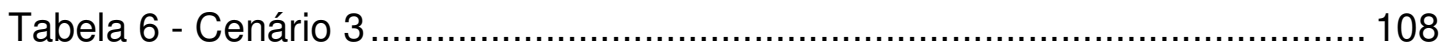




\section{LISTA DE EQUAÇÕES}

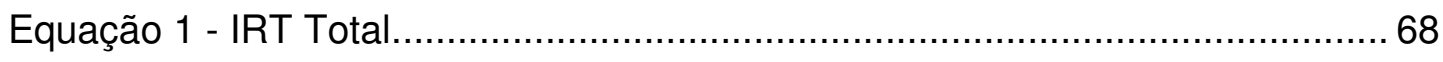

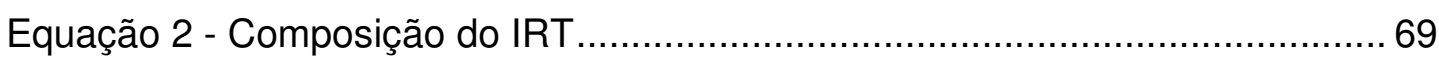

Equação 3 - Repasse da Sobrecontratação ................................................. 90

Equação 4 - Função Objetivo do Simulador ............................................... 101 


\section{LISTA DE ABREVIATURAS E SIGLAS}

ACL Ambiente de Contratação Livre

ACR Ambiente de Contratação Regulada

ANEEL Agência Nacional de Energia Elétrica

ASMAE Administradora de Serviços do Mercado Atacadista de Energia Elétrica

CCEAR Contrato de Compra e Venda de Energia Elétrica no Ambiente Regulado

CCEE Câmara de Comercialização de Energia Elétrica

CCPE Comitê Coordenador do Planejamento da Expansão

CMSE Comitê de Monitoramento do Setor Elétrico

CNAEE Conselho Nacional de Águas e Energia Elétrica

CVA Conta de Compensação de Variação de Valores de Itens da "Parcela A"

DNAEE Departamento Nacional de Águas e Energia Elétrica

EPE Empresa de Pesquisa Energética

ICMS Imposto sobre Circulação de Mercadorias e Prestação de Serviços

IGP-M Índice Geral de Preços de Mercado

MAE Mercado Atacadista de Energia Elétrica 


$\begin{array}{ll}\text { MCSD } & \text { Mecanismo de Compensação de Sobras e Déficits } \\ \text { MME } & \text { Ministério de Minas e Energia } \\ \text { MRE } & \text { Mecanismo de Realocação de Energia } \\ \text { ONS } & \text { Operador Nacional do Sistema } \\ \text { PLD } & \text { Preço de Liquidação das Diferenças } \\ \text { PPT } & \text { Programa Prioritário de Termoelétricas } \\ \text { RENCOR } & \text { Reserva Nacional de Compensação de Remuneração } \\ \text { RESEB } & \text { Reestruturação do Setor Elétrico Brasileiro } \\ \text { REVISE } & \text { Revisão do Setor Elétrico } \\ \text { SIN } & \text { Sistema Interligado Nacional } \\ \text { VR } & \text { Valor de Referência } \\ \text { VRA } & \text { Valor Anual de Referência }\end{array}$




\section{SUMÁRIO}

1 INTRODUÇÃO

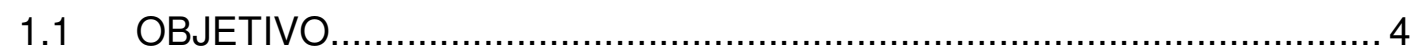

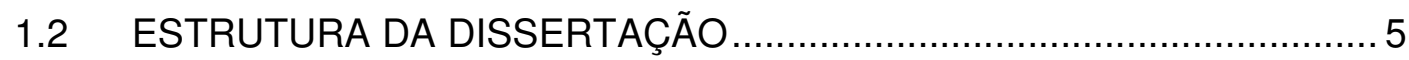

2 MODELO INSTITUCIONAL DO SETOR ELÉTRICO BRASILEIRO:

HISTÓRICO E PRINCIPAIS CARACTERÍSTICAS DE SUA FORMULAÇÃO ........ 7

2.1 HISTÓRICO DO SETOR ELÉTRICO BRASILEIRO …............................ 7

2.2 O PROJETO RE-SEB E O NOVO MODELO DO SETOR ELÉTRICO... 11

2.3 NOVAS INSTITUIÇÕES E SUAS ATRIBUIÇÕES ………................... 14

2.4 A TRANSIÇÃO PARA O "NOVÍSSIMO" MODELO ……....................... 15

2.4.1 O Racionamento de Energia .......................................................... 16

2.4.2 A Proposta da Nova Regulamentação - O "Novíssimo" Modelo..... 18

2.4.3 A Nova Estrutura Organizacional do Setor Elétrico.......................... 19

3 A CÂMARA DE COMERCIALIZAÇÃO DE ENERGIA ELÉTRICA - CCEE ... 22

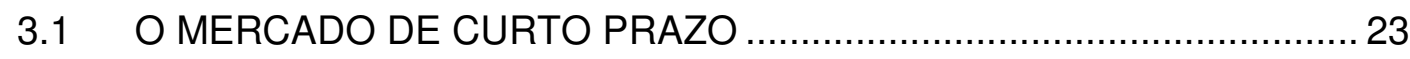

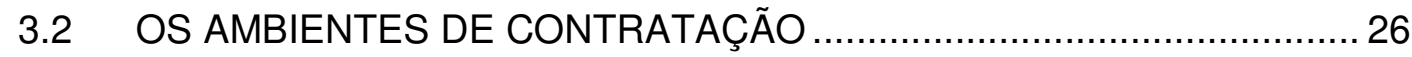

3.2.1 O Ambiente de Contratação Livre $(\mathrm{ACL})$...................................... 28

3.2.2 O Ambiente de Contratação Regulada (ACR) ............................... 28

3.3 OS DESAFIOS PARA AS CONCESSIONÁRIAS DE DISTRIBUIÇÃO .. 29

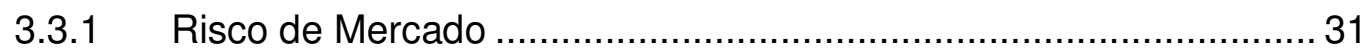

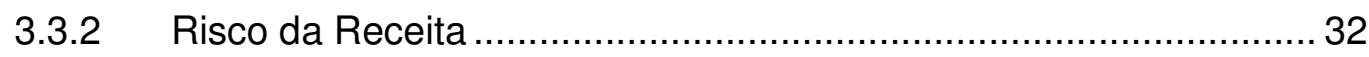

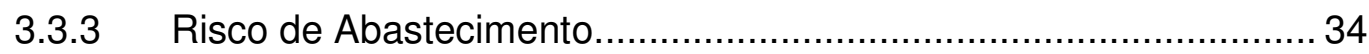

4 LEILÕES REGULADOS PARA AQUISIÇÃO DE ENERGIA ELÉTRICA ........ 36

4.1 LEILÕES DE ENERGIA EXISTENTE …............................................. 36

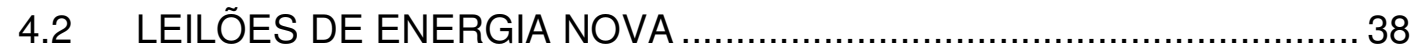

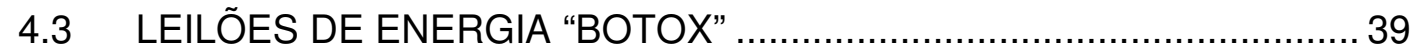

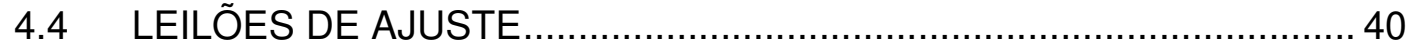

4.5 LEILÕES PARA AQUISIÇÃO DE ENERGIA DISTRIBUÍDA …............... 41

5 MECANISMOS DE MITIGAÇÃO DE RISCOS DE MERCADO DAS

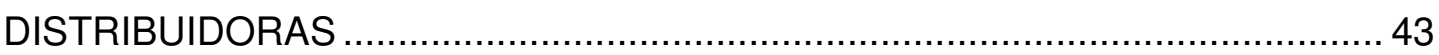

5.1 PARTICIPAÇÃO EM LEILÕES DE ENERGIA NOVA A-3.................... 45

5.2 PARTICIPAÇÃO EM LEILÕES DE ENERGIA EXISTENTE A-1 ............46 
5.3 PARTICIPAÇÃO EM LEILÕES DE AJUSTE.

5.4 AQUISIÇÃO DE ENERGIA PROVENIENTE DE GERAÇÃO

DISTRIBUÍDA

5.5 REDUÇÃO DE CONTRATOS POR SAÍDA DE CONSUMIDORES

LIVRES .... 49

5.6 REDUÇÃO DE CONTRATOS POR VARIAÇÃO DE MERCADO 49

5.7 MECANISMO DE COMPENSAÇÃO DE SOBRAS E DÉFICITS (MCSD)

5.8 ALOCAÇÃO DOS RISCOS DE MERCADO E MECANISMOS DE

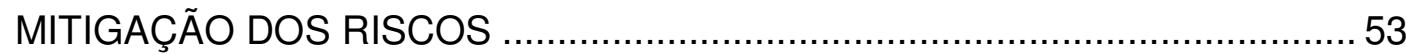

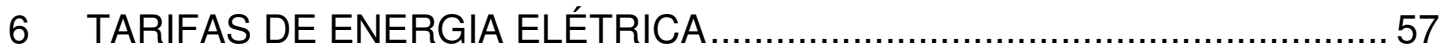

6.1 COMPOSIÇÃO DA RECEITA REQUERIDA (PARCELAS "A" E "B")..... 59

6.1.1 Parcela "A" - Custos Não Gerenciáveis ................................................... 60

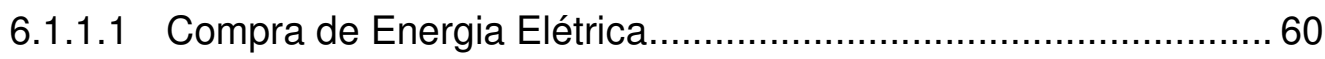

6.1.1.2 Encargos Setoriais e Custos com Transporte de Energia ............ 61

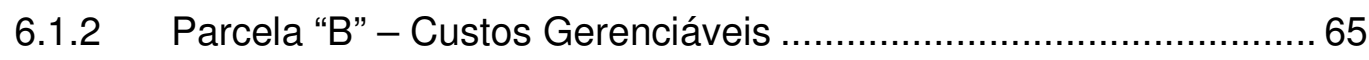

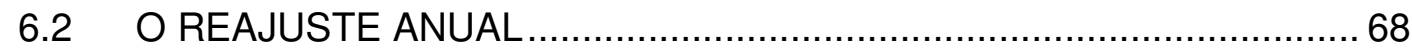

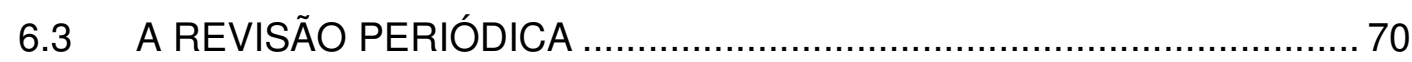

6.3.1 Reposicionamento Tarifário ......................................................... 71

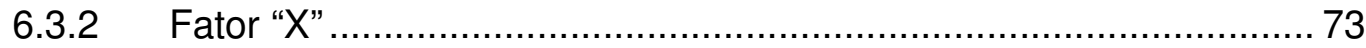

7 O REPASSE DOS CUSTOS DE AQUISIÇÃO DE ENERGIA ELÉTRICA ÀS

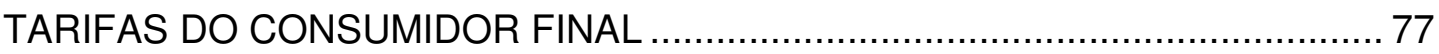

7.1 REPASSE DOS CUSTOS DE AQUISIÇÃO DE ENERGIA ELÉTRICA

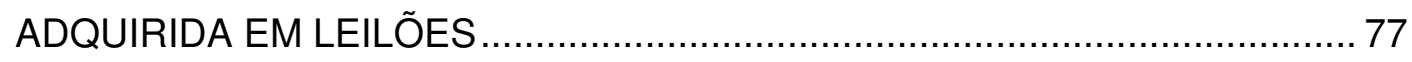

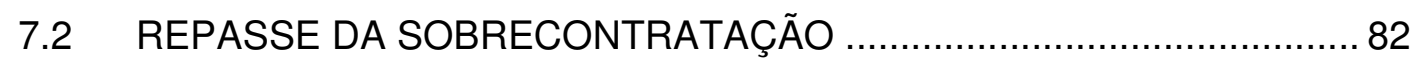

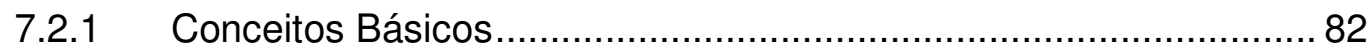

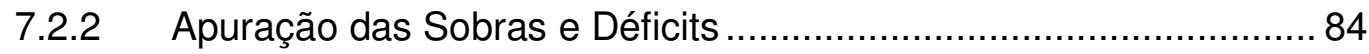

7.2.3 A Sazonalização de Energia Elétrica no processo de Repasse dos

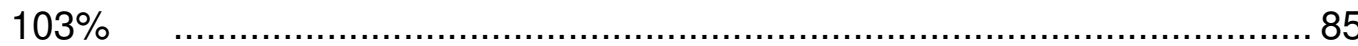

7.3 A CONTA DE COMPENSAÇÃO DE VARIAÇÃO DE VALORES DE

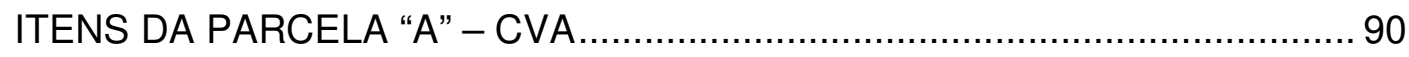

7.4 TRATAMENTO DAS PERDAS REGULATÓRIAS..................................92

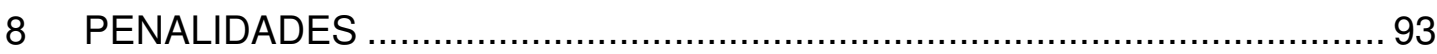




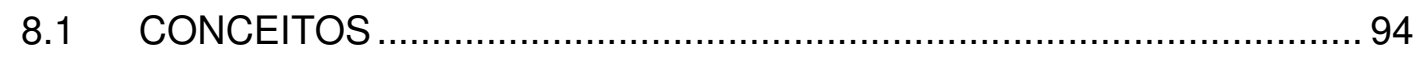

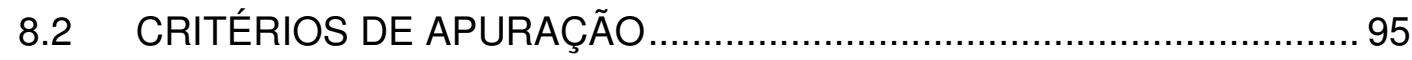

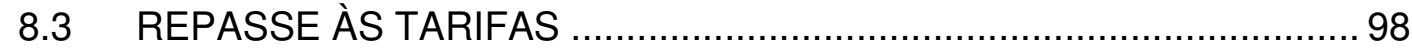

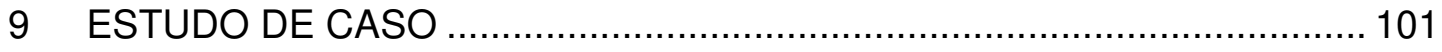

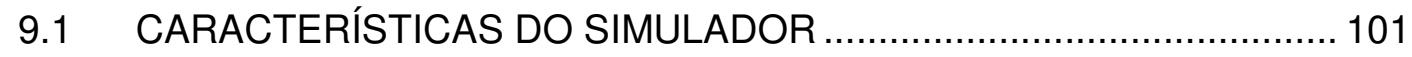

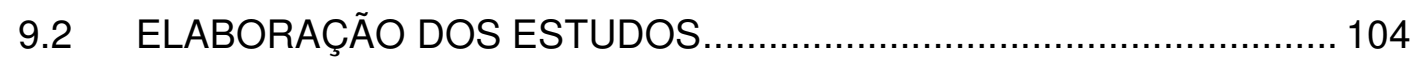

9.3 ANÁLISE DOS RESULTADOS OBTIDOS …......................................... 111

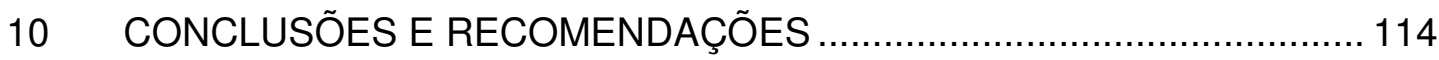

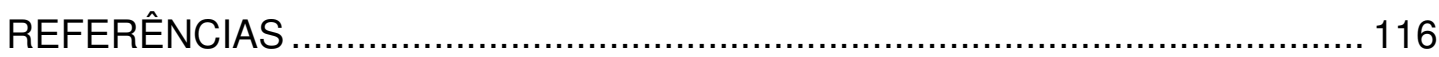




\section{INTRODUÇÃO}

Em qualquer parte do mundo, os países buscam sistematicamente o desenvolvimento e, por conseqüência, o crescimento da economia, o que acaba trazendo riquezas ao país, gerando empregos, movimentando a economia, enfim, proporcionando melhorias de um modo geral.

Existem muitos fatores de extrema importância que contribuem para o crescimento de um país, como educação, segurança, infra-estrutura, entre outros. No entanto, se alguns desses fatores não corresponderem ao planejado pelas entidades governamentais, o crescimento do país fica seriamente comprometido. Diante desse contexto, há que se destacar que, dentre os fatores acima descritos, a infra-estrutura é de suma importância e, nesse contexto, a questão de disponibilidade de energia elétrica é de primordial relevância. Se um país, um estado, uma cidade têm a pretensão de proporcionar o crescimento da economia, é necessário que sejam dadas condições mínimas de infra-estrutura que suporte esse crescimento, entre eles, a disponibilidade de energia elétrica.

Os fatores relacionados a infra-estrutura podem ser de natureza logística, de transportes, de telecomunicações, e de outros tantos fatores. Um dos fatores mais relevantes está relacionado e energia elétrica.

É difícil de se imaginar o desenvolvimento e o crescimento de uma região sem o crescimento no consumo de energia elétrica. Dessa forma, é preciso que o planejamento e a execução das ações planejadas sejam coerentes e feitas de forma conjunta, respeitando as limitações existentes.

Além disso, é preciso que sejam criados mecanismos que garantam o sucesso e a continuidade de ações, tornando o setor sustentável por si próprio e atraindo novos investimentos ao mesmo. 
Como exemplo das conseqüências de má gestão e falta de mecanismos adequados à sobrevivência do setor, podemos citar o racionamento de energia elétrica ocorrido entre 2001 e 2002.

Inúmeros fatores levaram o Brasil a passar pelo racionamento de energia em 2001, e os dois dos mais importantes foram exatamente os citados anteriormente, ou seja, falta de sinergia entre planejamento e execução dos novos empreendimentos para reforçar a oferta do sistema interligado, como também a ineficácia dos mecanismos de atração de investimentos existentes na época.

No passado, o governo federal, responsável pelo planejamento da expansão do setor elétrico e controlador da maioria das empresas do setor, utilizava essas empresas para promover políticas governamentais, o que levou a uma situação de déficit financeiro permanente nos balanços das empresas, com a conseqüente falta de recursos para investir na expansão da oferta de energia. Posto que o governo federal também não tinha recursos para investir naquele momento, o setor ficou, por um bom tempo estagnado, sem que houvessem os investimentos necessários para a expansão do seu parque gerador.

É importante citar que os pontos anteriormente ressaltados foram apenas alguns dos fatores que culminaram com o racionamento de energia elétrica ocorrido entre 2001 e 2002, sem pretensão de cobertura exaustiva, na medida em que existem inúmeros outros pontos de alguma relevância, no que tange o assunto em questão.

Com a reestruturação do setor elétrico, muitos pontos, citados ao longo desse trabalho, foram corrigidos e uma nova dinâmica no setor elétrico brasileiro foi dada, criando novas figuras de mercado, novas entidades, com atribuições até então inexistentes no setor.

Foram dados incentivos e estímulos para que as empresas privadas fossem as responsáveis por essa expansão na oferta de energia e, criados mecanismos que garantissem uma remuneração justa aos investidores e as empresas que 
fizessem os serviços relacionados a geração, transmissão e distribuição de energia elétrica.

Criou-se a figura do comercializador de energia e foi introduzida a figura do Mercado Atacadista de Energia - MAE, onde alguns agentes de mercado poderiam participar negociando livremente a compra e venda de energia elétrica com outros agentes do setor.

Alguns incentivos à gestão eficiente foram agregados ao setor elétrico, mais especificamente no que tange as empresas de distribuição de energia elétrica.

È importante destacar que todo esse processo de reestruturação do setor elétrico brasileiro teve início no período imediatamente anterior ao governo do expresidente Fernando Henrique Cardoso, período chamado de pré-reestruturação. Em seu governo, o ex-presidente Fernando Henrique Cardoso promoveu uma grande reestruturação do setor elétrico brasileiro, que foi o grande marco para o setor. Na seqüência, o governo do presidente Luís Inácio Lula da Silva deu continuidade ao processo de reestruturação, implantando o modelo do setor elétrico vigente atualmente.

Diante desse contexto, os agentes distribuidores de energia elétrica atualmente podem repassar às tarifas dos consumidores finais os custos relativos a aquisição de energia elétrica, desde que a aquisição dessa energia tenha sido realizada de maneira eficiente, levando em consideração aspectos relativos a regulamentação do setor elétrico brasileiro. 


\subsection{OBJETIVO}

Este trabalho tem como objetivo analisar os principais mecanismos de mitigação de riscos de mercado das distribuidoras envolvidos no processo de repasse dos custos de aquisição de energia elétrica às tarifas dos consumidores finais.

Toda empresa distribuidora de energia elétrica tem a função principal de entregar o produto, no caso a energia elétrica, ao consumidor final, devendo ser remunerado de maneira justa por esse serviço.

No entanto, a regulamentação vigente limita o repasse de todos os custos de aquisição de energia elétrica às tarifas do consumidor final, com o objetivo de promover a modicidade tarifária e estimular as empresas de distribuição de energia elétrica a fazer uma contratação e a gestão eficiente do insumo a ser entregue ao consumidor. Sendo a distribuição um segmento de atividade estritamente regulado, a ótica tarifária que prevalece hoje é a de regulação por incentivos ("price cap"), em substituição à prática de tarifa pelo custo, utilizada no passado.

Para que as empresas possam fazer essa contratação e gestão eficiente da energia, existem mecanismos de mitigação de riscos de mercado das distribuidoras. As distribuidoras podem se utilizar desses mecanismos de tal forma que o repasse dos custos de aquisição de energia elétrica seja otimizado, recebendo assim uma remuneração justa pelo serviço prestado.

Por fim, esse trabalho pretende esquadrinhar e avaliar os dispositivos previstos na regulamentação, inserindo um estudo de caso que analisa o portfólio de contratação de uma empresa de distribuição de energia elétrica fictícia, simulando variações nos níveis de contratação da mesma bem como no portfólio, avaliando a utilização dos mecanismos de mitigação de riscos de mercado e as alternativas simuladas, e identificando os pontos de sucesso e os pontos a serem melhorados na gestão e contratação da distribuidora. 


\subsection{ESTRUTURA DA DISSERTAÇÃO}

No capítulo 2 é feito um breve descritivo do histórico do setor elétrico brasileiro, mostrando sua evolução desde o início da história da eletricidade no Brasil até o modelo do setor elétrico vigente, incluindo a descrição das principais instituições do setor, e suas principais atribuições.

No capítulo 3 é apresentada a Câmara de Comercialização de Energia Elétrica, descrevendo sua forma de funcionamento, e os ambientes de contratação existentes.

Já no capítulo 4 introduz-se uma explanação sobre os vários tipos de leilões de energia utilizados pelo agente distribuidor para contratar a totalidade da sua carga.

No capítulo seguinte, faz-se uma análise sobre os mecanismos de mitigação de riscos de mercado das distribuidoras, descrevendo os principais dispositivos disponíveis e suas características de utilização.

Em seguida, é feito um relato sobre os processos de revisão e reajuste tarifário das distribuidoras, tendo em vista que o repasse ou não dos custos de energia elétrica ao consumidor final é feito via revisão e reajuste tarifário.

No capítulo 7 é apresentada uma análise sobre o repasse dos custos de aquisição de energia elétrica às tarifas dos consumidores finais, levando em consideração todos os pontos identificados nos capítulos anteriores.

No capítulo 8 é dado um tratamento sobre as penalidades às quais as distribuidoras estão sujeitas, bem como os critérios de apuração e o repasse à tarifa. 
Já no capítulo 9, é feito um estudo de caso, analisando o protfólio de contratação de uma empresa de distribuição de energia elétrica fictícia, simulando variações nos níveis de contratação da mesma bem como no portfólio, avaliando a utilização dos mecanismos de mitigação de riscos de mercado e as alternativas simuladas, identificando os pontos de sucesso e os pontos a serem melhorados na gestão e contratação da distribuidora.

Por fim, são elaboradas as conclusões e recomendações do trabalho, verificando a eficácia da utilização dos mecanismos de mitigação de riscos de mercado das distribuidoras. 


\section{MODELO INSTITUCIONAL DO SETOR ELÉTRICO BRASILEIRO: HISTÓRICO E PRINCIPAIS CARACTERÍSTICAS DE SUA FORMULAÇÃO}

Para que sejam completamente compreendidos os conceitos a serem discutidos nessa dissertação, é preciso que inicialmente, seja feito um relato do histórico do setor elétrico brasileiro com ênfase no passado recente, descrevendo as principais entidades, as principais alterações ocorridas ao longo do tempo e, principalmente, descrevendo o funcionamento do mercado de energia elétrica para cada classe de agente do setor.

\subsection{HISTÓRICO DO SETOR ELÉTRICO BRASILEIRO}

A história da eletricidade no Brasil inicia-se em 1879, com a primeira experiência pública de utilização de lâmpada elétrica. A experiência consistiu na iluminação da Estação Central da Estrada de Ferro D. Pedro II, atual Central do Brasil, na cidade do Rio de Janeiro. A partir disso, a eletricidade passou a ter maior importância no contexto de evolução e crescimento das cidades e, no início do século XX, uma empresa passou a dominar o setor de eletricidade no Brasil: Light.

A Light foi a empresa pioneira e a principal concessionária no setor de eletricidade no Brasil, compartilhando. por muitos anos a responsabilidade pelo atendimento ao mercado consumidor do setor elétrico brasileiro com diversas outras empresas, de porte e abrangência de área de concessão bastante inferior à da própria Light. Em meados dos anos 20 surgiu a empresa Anforp, oriunda da aquisição de diversas empresas menores do setor, que passou a dividir os serviços do setor com a Light, porém numa proporção bem menor do que a sua concorrente. 
Os serviços foram crescendo gradativamente e, nessa época, não havia nenhuma, ou quase nenhuma, regulamentação e fiscalização por parte do governo. Dessa forma, as empresas poderiam celebrar contratos de fornecimento de energia elétrica da maneira que entendessem mais conveniente e nos casos que julgassem ser necessário.

Referente à tarifa utilizada nessa época, no início não havia regulamentação, sendo que cabia as empresas prestadoras do serviço de geração e distribuição de energia definir o valor a ser cobrado dos contribuintes, sem qualquer interveniência do governo. Posteriormente, surgiu o primeiro indício de regulamentação de tarifas, que consistia no reajuste tarifário de $50 \%$ do valor da cotação do ouro da época. Essa metodologia de reajuste ficou conhecida como a "Cláusula Ouro", uma vez que o reajuste era efetuado em função da cotação do ouro na época.

O setor foi evoluindo e no ano de 1934, o Ministério de Agricultura, ao qual o setor elétrico estava afeto, promulgou o Código das Águas. A promulgação desse código foi de suma importância para o setor elétrico, pois foi a primeira regulamentação efetiva dos serviços e da industria de energia elétrica no país, através do qual a União passou a ser o único poder concedente. A partir de então, o aproveitamento do potencial hidrelétrico passou a depender de autorização ou de outorga de concessão. As tarifas passaram a ser fixadas segundo os custos de operação e o valor histórico dos investimentos, não sendo reajustadas de acordo com a variação da inflação, o que na prática provocaria graves efeitos colaterais para novos investimentos no setor.

No final dos anos 30 foi criado o Conselho Nacional de Águas e Energia Elétrica CNAEE, reforçando a questão da regulamentação dos serviços de eletricidade.

A tímida intervenção do governo não coibiu a crise energética que se iniciou no período pós-guerra e estendeu sobre o país na década de 50, uma vez que as empresas privadas da época não reinvestiam no próprio país os lucros obtidos com a venda de energia elétrica. 
Sendo assim, o governou interveio no setor elétrico com maior veemência criando a Companhia Hidro-Elétrica do São Francisco (Chesf), com a tarefa principal de construir e operar a Usina de Paulo Afonso - inaugurada em 1955. Os governos estaduais resolveram seguir o mesmo rumo do governo federal e criaram as suas próprias empresas de energia elétrica.

Os anos 60 foram marcados por grandes mudanças no setor elétrico, como o crescimento da capacidade instalada e da malha de transmissão de energia elétrica. Além disso, houve grandes mudanças no que tange a regulamentação do setor, como a criação do Ministério de Minas e Energia - MME, do Departamento Nacional de Águas e Energia Elétrica - DNAEE, e da Eletrobrás.

No período compreendido entre as décadas de 70 e 80 , o setor elétrico atingiu seu ápice, representado pelo "milagre econômico", experimentando também o início de seu declínio, passando incólume pela crise do petróleo em 1973. Nessa época, conhecida como "milagre brasileiro", o setor deu início às maiores obras de geração hidrelétrica do País, ao início do programa nuclear brasileiro (usina nuclear Angra I, entrando em fase de testes em 1981, em operação experimental em março de 1982 e em operação comercial em janeiro de 1985 - Angra II somente entraria em operação em 2000), desenvolveu os grandes sistemas de transmissão em 440 e 500 kV e os sofisticados sistemas de supervisão e controle, celebrando ainda o tratado de Itaipu, cuja obra iniciou-se em 1975. Nessa período foi consolidada a estrutura básica do sistema Eletrobrás, composta pela Eletronorte, Eletrosul, Furnas e Chesf.

O final dos anos 80 foi marcado pelo fim do ciclo dos governos militares, com a eleição do Presidente Tancredo Neves em 1984. Para o setor elétrico, esse período pode ser considerado como o mais conturbado de sua história, pois, além do controle tarifário para uma frustrada tentativa de controle inflacionário por parte do governo, houve também a corrida de algumas empresas, já endividadas pelas obras da década anterior, aos suppliers credits, que acabou por complicar ainda mais sua saúde financeira. Houve também o RENCOR e o frustrado Projeto de 
Revisão do Setor Elétrico - REVISE. Foi também a década dos black-outs e da inadimplência setorial.

No início dos anos 90, começou um amplo processo de privatização no Brasil, englobando os mais variados setores de infra-estrutura do país, entre eles o setor elétrico. A privatização do setor elétrico foi motivada pelo fato de que as empresas estatais não eram geridas de uma maneira muito eficiente em algumas atividades como, por exemplo, no corpo administrativo dessas empresas, onde muitos governantes aproveitavam de sua posição estratégica para conseguir benefícios próprios ou a pessoas próximas a eles. Existia a necessidade de redução da dívida pública e não havia dinheiro para investimento do setor público.

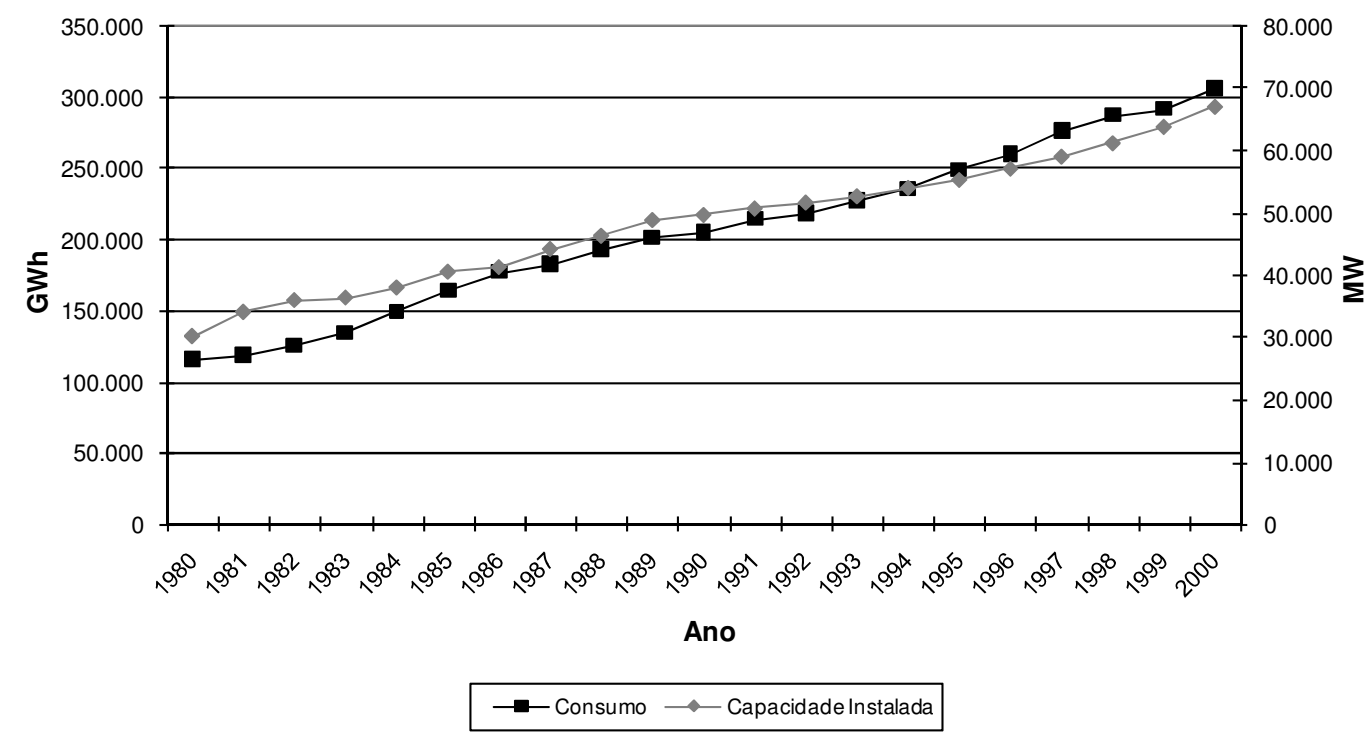

Figura 1 - Evolução da Capacidade Instalada e Consumo

A partir da figura 1 pode-se notar que, analisando-se o período compreendido entre 1980 e 2000, a evolução do consumo de energia no Brasil superou a evolução da capacidade instalada no mesmo período, gerando assim sistematicamente um déficit de oferta de energia, que culminou no racionamento ocorrido em 2001 e pode resultar num fato semelhante nos próximos anos, caso não haja nenhuma atuação governamental no sentido de promover a expansão da oferta de energia. 


\subsection{O PROJETO RE-SEB E O NOVO MODELO DO SETOR ELÉTRICO}

Em 1ำ de Agosto de 1996 foi implantado o Projeto RE-SEB, Reestruturação do Setor Elétrico Brasileiro, cujo objetivo principal era reestruturar o setor elétrico brasileiro a partir de duas (2) premissas básicas:

- Assegurar que o setor fosse economicamente eficiente;

- Assegurar os investimentos necessários para a expansão da oferta de energia.

O Projeto foi encerrado em Agosto de 1998 e foi a base do Novo Modelo do Setor Elétrico. Dessa forma, pode-se afirmar que o Novo Modelo do Setor Elétrico foi elaborado durante o Projeto RE-SEB e implantado logo em seguida à finalização do referido projeto. $O$ hiato entre o término do projeto e a sua fase de funcionamento, contemplou apenas o tempo necessário para o estabelecimento do Marco Regulatório correspondente.

O Novo Modelo do setor elétrico alterou significativamente o funcionamento e toda regulamentação vigente até então. Foi uma alteração significativa, que impactou em todos os setores relacionados a energia elétrica (geração, transmissão, distribuição, comercialização e consumo)

A primeira grande alteração foi referente à segregação das principais atividades do setor em geração, transmissão, distribuição e comercialização. No novo modelo do setor, essas atividades são tratadas com atividades independentes, e existem limites para a co-participação do mesmo agente em pelo menos duas (2) dessas atividades. Dessa forma, as empresas de energia tiveram que desverticalizar as suas atividades, separando-as nas atividades acima descritas. Além disso, foi introduzido um novo agente no mercado: o comercializador de 
energia. Esse agente poderia comprar e vender energia, sem necessariamente ter um empreendimento de geração ou de consumo, apenas representando os outros agentes de mercado.

Para viabilizar a comercialização da energia elétrica, as empresas de transmissão e distribuição de energia elétrica deviam permitir o "livre acesso" aos demais agentes de mercado, levando em consideração os níveis mínimos de qualidade exigidos pela regulamentação vigente. Para tal, o agente transmissor ou distribuidor receberia um "pedágio" pelo uso da rede por outros agentes de mercado.

Foi dada também especial ênfase à figura do consumidor livre que havia sido introduzida pela Lei no 9074, de julho de 1995. Inicialmente, para poder participar do mercado livre e ser um agente consumidor livre, o consumidor deveria atender alguns pré-requisitos, como ser atendido em tensão igual ou superior a $69 \mathrm{kV}$ e ter demanda contratada acima de $10 \mathrm{MW}$. Posteriormente, esses limites foram alterados, sendo que a demanda contratada deveria estar acima de $3 \mathrm{MW}$. Atualmente não existe condicionante vinculado à tensão de fornecimento para consumidores ligados a partir de julho de 1995, sendo que a demanda contratada deve ser maior que 0,5 MW. Para consumidores cuja demanda contratada esteja compreendida entre $0,5 \mathrm{MW}$ e $3 \mathrm{MW}$, a contratação deve ser feita única e exclusivamente a partir de fontes incentivadas de energia.

Os contratos de compra e venda de energia elétrica poderiam ser livremente negociados entre as partes, e posteriormente registrados e homologados na CCEE (cuja denominação antiga era MAE) e na Aneel, respectivamente.

Foi criado o Mercado Atacadista de Energia Elétrica - MAE, que posteriormente passou a ser denominado de Câmara de Comercialização de Energia Elétrica CCEE, ambiente onde seriam, e continuam sendo efetuadas, as negociações referentes ao mercado livre. Nesse ambiente seria feita a contabilização e a liquidação financeira dos agentes de mercado. 
Para viabilizar a negociação no Mercado de Curto Prazo, os consumidores finais e distribuidores eram obrigados a contratar apenas $85 \%$ da sua carga, sendo que os $15 \%$ restantes poderiam ser livremente negociados no curto prazo, sendo permitida, inclusive, a exposição direta aos preços do mercado "spot". Posteriormente esses limites foram alterados para 95\% e 5\%, respectivamente. A possibilidade de ter uma parcela da carga descontratada foi um dos grandes problemas do Novo Modelo, uma vez que os agentes de mercado passaram a operar no mercado de curto prazo e a expansão da oferta de energia ficou comprometida. Essa deficiência foi corrigida em uma etapa seguinte de reestruturação, conhecida como "Novíssimo" Modelo ${ }^{1}$ com a obrigatoriedade da contratação de $100 \%$ da carga dos consumidores.

Ainda no Novo Modelo, do setor foi criado o Operador Nacional do Sistema ONS, entidade responsável pela programação, operação e despacho da geração elétrica no Sistema Interligado Nacional - SIN, e administração da rede básica. Ao ONS caberia a função de otimizar o despacho das usinas. Para minimizar os impactos dos interesses financeiros das empresas e da otimização do despacho das usinas pelo ONS, foram criados mecanismos econômicos de alocação de energia, como por exemplo o Mecanismo de Realocação de Energia - MRE, de tal forma que o risco hidrológico fosse compartilhado entre todos os agentes de mercado, desvinculando a geração física da disponibilidade energética para fins comerciais. Esse mecanismo foi criado com o objetivo principal de minimizar o risco hidrológico, ajudando assim a garantir a modicidade tarifária do Novo Modelo.

As tarifas de energia elétrica continuaram a ser reguladas para os consumidores cativos, mas passaram a ser livremente negociadas entre os agentes participantes do mercado livre.

Outro ponto a se destacar foi a criação do Comitê Coordenador do Planejamento da Expansão - CCPE, cuja principal função era a de realizar o planejamento da expansão do setor elétrico brasileiro, independentemente dos interesses privados

\footnotetext{
${ }^{1}$ Refere-se usualmente, no jargão do setor, à terminologia "Novíssimo Modelo", para o modelo vigente, formulado no início do $1^{\circ}$ mandato do Governo Lula.
} 
envolvidos. Atualmente, essa entidade é denominada de Empresa de Pesquisa Energética - EPE, como será visto a seguir.

Essas foram as principais alterações do modelo do setor elétrico, que possibilitaram que as premissas básicas fossem atendidas.

\subsection{NOVAS INSTITUIÇÕES E SUAS ATRIBUIÇÕES}

Com a reforma do Setor Elétrico, descrita anteriormente, houve a necessidade de estruturar uma nova forma de funcionamento do setor. Dessa forma, algumas instituições foram criadas e as novas atribuições, oriundas da reforma do setor, foram destinadas a essas novas instituições, enquanto que outras instituições tiveram as suas atividades e atribuições totalmente modificadas.

As principais alterações referente a criação de novas instituições e suas funções principais foram:

- $\quad$ Agência Nacional de Energia Elétrica - ANEEL: entidade governamental responsável pela regulação e fiscalização das atividades voltadas ao setor elétrico, como geração, transmissão, distribuição, comercialização, entre outras. Responsável também por outorgas de concessões, autorizações ou permissões de novas instalações ou serviços de energia elétrica ${ }^{2}$, por garantir a modicidade tarifaria, por estimular a competição e o uso eficiente da energia elétrica pelos agentes de mercado, entre outras atribuições.

- $\quad$ Mercado Atacadista de Energia Elétrica - MAE: ambiente onde se realizam as operações de compra e venda de energia elétrica do Sistema Interligado Nacional - SIN, no mercado de curto prazo. Nesse ambiente, também são

\footnotetext{
${ }^{2}$ Atualmente o papel do Poder Concedente foi resgatado pelo MME, que é o responsável pelas outorgas de concessões.
} 
efetuadas as contabilizações e liquidações financeiras do mercado "spot" (mercado das diferenças). A entidade responsável pelas operações acima descritas é a Administradora de Serviços do Mercado Atacadista de Energia Elétrica - ASMAE.

- $\quad$ Operador Nacional do Sistema Elétrico - ONS: entidade privada sem fins lucrativos, cujas principais atribuições foram definidas como planejar e programar a operação do sistema, efetuar o despacho centralizado da geração, propor ampliações e reforços nas instalações que compõem o Sistema Interligado Nacional - SIN, entre outras.

- $\quad$ Comitê Coordenador do Planejamento da Expansão - CCPE: entidade ligada diretamente ao Ministério de Minas e Energia (MME) cujas principais atribuições eram orientar as ações do governo para assegurar o fornecimento de energia elétrica nos padrões mínimos exigidos, elaborar um planejamento indicativo de investimentos, estabelecer a expansão da malha de transmissão da maneira mais adequada possível.

Como será visto adiante, algumas dessas entidades tiveram a sua denominação e atribuições alteradas a partir da criação do "Novíssimo" Modelo do setor elétrico.

\subsection{A TRANSIÇÃO PARA O "NOVÍSSIMO" MODELO}

A reforma promovida no Setor Elétrico tinha como principais objetivos promover a modicidade tarifária e estimular a expansão do parque gerador, transferindo para a iniciativa privada a responsabilidade pelos investimentos no setor.

No entanto, um fator exógeno aos objetivos e premissas adotadas na elaboração do Novo Modelo do setor acabou por prejudicar o bom funcionamento do mesmo: 
o Racionamento de Energia Elétrica, que ocorreu entre 2001 e 2002, e que será descrito com maiores detalhes a seguir.

\subsubsection{O Racionamento de Energia}

O Racionamento foi fruto de uma série de fatores que comprometeram a expansão do parque gerador e do sistema de transmissão de energia elétrica. Entre os principais motivos destacam-se o fato de que no passado a maioria das empresas geradoras e transmissoras de energia elétrica eram controladas pelo governo federal, através da Eletrobrás e de suas subsidiárias. Dessa forma, o governo utilizava as empresas de energia elétrica como instrumento de políticas governamentais, o que acabava resultando em resultados negativos para as empresas, mas positivo para a política de governo. Isso resultou num déficit nas empresas do setor de tal forma que não havia recursos públicos para investir na expansão do parque gerador.

Nesse sentido, porém mais próximo do período em que ocorreu o racionamento, o grande viés aconteceu devido a ineficácia dos mecanismos que incentivavam a iniciativa privada a investir no setor elétrico brasileiro, de tal maneira que não havia grandes obras que garantissem a expansão do parque gerador. Dessa forma, a cada dia que se passava, a curva de Oferta $x$ Demanda se aproximava mais da intersecção, e quando isso ocorresse, como de fato ocorreu, o resultado seria o racionamento, pois isso significava que não havia mais disponibilidade de oferta de energia no sistema.

Outro aspecto relevante que contribuiu significativamente para que ocorresse 0 racionamento em 2001, decorre do fato de que o Planejamento do Sistema de Transmissão foi deixado em segundo plano pelos governos, uma vez que não havia dinheiro para fazer as obras apontadas pelo planejamento. Sendo assim, a malha de transmissão do Sistema Interligado Nacional - SIN ficou 
sobrecarregada, comprometendo assim o intercâmbio de energia elétrica entre as regiões geo-elétricas em que se divide o País.

Já prevendo uma dificuldade no abastecimento de energia para os anos que se avizinhavam, o governo federal lançou em fevereiro de 2000 o Programa Prioritário de Termoelétricas - PPT, que previa a construção de 49 usinas termoelétricas, acrescentando aproximadamente $15.000 \mathrm{MW}$ ao sistema interligado. No entanto, o programa encontrava sérias restrições para apresentar o resultado esperado devido a uma série de restrições impostas pela iniciativa privada, como: maior transparência nos preços do gás natural praticados pela Petrobras, acessibilidade aos dutos de transporte, redução da demora na aprovação da licença ambiental e, principalmente, a garantia de compra e proteção contra o risco cambial. Após intensas discussões e um ano e meio de atraso, o programa finalmente foi posto em prática, mas não em tempo hábil para evitar o racionamento de 2001. Além disso, o programa não teve a adesão da iniciativa privada que o governo federal esperava, sendo que apenas 10 usinas termoelétricas foram postas em funcionamento, acrescentando $1.527 \mathrm{MW}$ no sistema, ou seja, $10 \%$ do valor previsto pelo governo federal.

Associado a esses fatores, houve um período hidrológico desfavorável com relação ao regime de chuvas e, conseqüentemente, às afluências dos principais rios do Brasil, que abastecem os principais reservatórios das maiores usinas. Tendo em vista que a matriz energética brasileira era e continua sendo basicamente hidroelétrica, a associação desses fatores culminou com 0 racionamento vivido entre 2001 e 2002, em algumas regiões do país.

Para melhor caracterizar o evento, podemos citar o fato de que o racionamento de energia ocorreu somente nas regiões Sudeste/Centro-Oeste e Nordeste, no período de $1^{\circ}$ de Junho de 2001 a 28 de Fevereiro de 2002, e na região Norte, no período de 15 de Agosto de 2001 a 28 de Fevereiro de 2002. Se houvesse uma malha de transmissão mais robusta, que comportasse um intercâmbio maior de energia elétrica entre os submercados, o racionamento poderia ser minimizado, embora dificilmente evitado. 
Há que se ressaltar que a região Norte fez parte do racionamento somente pelo fato de contribuir para o suprimento da região Nordeste, uma vez que a região Norte é predominantemente exportadora de energia, enquanto que a região Nordeste é predominantemente importadora de energia. A região mais afetada com o racionamento foi a região Sudeste/Centro-Oeste.

A partir disso, foi criado o Comitê de Revitalização, cuja principal função era identificar as imperfeições do modelo vigente e propor alternativas de aperfeiçoamento no sentido de promover a expansão da oferta de energia elétrica.

O Comitê de Revitalização realizou um trabalho muito valioso, que serviu de base para o "Novíssimo" Modelo do Setor Elétrico.

\subsubsection{A Proposta da Nova Regulamentação - O “Novíssimo” Modelo}

A partir do trabalho realizado pelo Comitê de Revitalização, o Ministério de Minas e Energia (MME), então sob o comando da ministra Dilma Roussef, elaborou a nova proposta de regulamentação do setor elétrico, cujas principais premissas eram:

- $\quad$ Promover a modicidade tarifária, estimulando a contratação eficiente de energia para os consumidores regulados;

- Garantir a segurança no suprimento de energia elétrica;

- $\quad$ Promover a inserção social, através de programas de universalização.

Para atender a primeira premissa do novo modelo, as principais ações do ministério foram de determinação para que a compra de energia sempre 
ocorresse em leilões (na modalidade menor tarifa) para as empresas reguladas (distribuidoras), bem como houvesse contratação em separado para a energia de usinas novas e de usinas já em operação, dando ênfase à competição "pelo mercado", ao invés de competição "no mercado".

Essa segregação da contratação de energia foi de vital importância, pois as empresas distribuidoras passaram a contratar energia vislumbrando um horizonte de longo prazo para contratação, com incentivos para se beneficiarem da contratação de energia, quando eficiente. Na nova ótica de atendimento às suas necessidades, as distribuidoras declaram suas necessidade energéticas para um horizonte 5 anos à frente do ano corrente e, em um processo de leilão público, os agentes geradores disputam os blocos de carga ofertados, visualizando contratos de venda com duração mínima de 15 anos e máxima de 35 anos (competição pelo mercado). Na primeira etapa do processo de re-estruturação do setor, a diferença fundamental pode ser resumida no fato de que as distribuidoras não contratavam a totalidade de sua necessidade, com o objetivo de se beneficiar das condições do mercado de curto prazo, já que tinham essa possibilidade. Como conseqüência, os geradores passaram a competir por contratos no ambiente de curto prazo, caracterizando a "competição no mercado".

Nos capítulos seguintes são detalhados os mecanismos de contratação e as principais alterações do "Novíssimo" Modelo.

\subsubsection{A Nova Estrutura Organizacional do Setor Elétrico}

Com o objetivo de operacionalizar as propostas feitas com a reestruturação do novo modelo do setor de energia elétrica, novas instituições foram criadas, e algumas instituições existentes tiveram as suas atribuições redefinidas.

As instituições criadas foram: 
- $\quad$ Empresa de Pesquisa Energética - EPE: entidade governamental criada com função principal de elaborar estudos de longo prazo no que tange a definição da Matriz Energética, elaborar estudos de planejamento da expansão do setor elétrico (geração e transmissão), elaborar estudos de viabilidade de empreendimentos de geração e obtenção de Licença Prévia Ambiental junto aos órgãos competentes, entre outras atribuições;

- $\quad$ Câmara de Comercialização de Energia Elétrica - CCEE: entidade privada sem fins lucrativos que sucedeu ao MAE, absorvendo todas as suas funções, estruturas organizacionais e operacionais, além de receber novas atribuições como realizar leilões de compra e venda de energia elétrica para as distribuidoras, exercer as funções de contabilização e liquidação do mercado de curto prazo nos ambientes de contratação livre e regulado, entre outras atribuições pré-existentes;

- Comitê de Monitoramento de Setor Elétrico - CMSE: entidade governamental responsável pelo monitoramento das atividades relacionadas ao setor elétrico, bem como propor ações ao Comitê Nacional de Política Energética - CNPE no sentido de otimizar o uso da energia e minimizar o seu custo aos consumidores finais.

Além dessas novas entidades, entidades já existentes tiveram algumas de suas atribuições redefinidas, ou receberam novas atribuições.

Considerando o exposto, a estrutura organizacional do setor elétrico brasileiro pode ser visualizada na ilustração a seguir: 


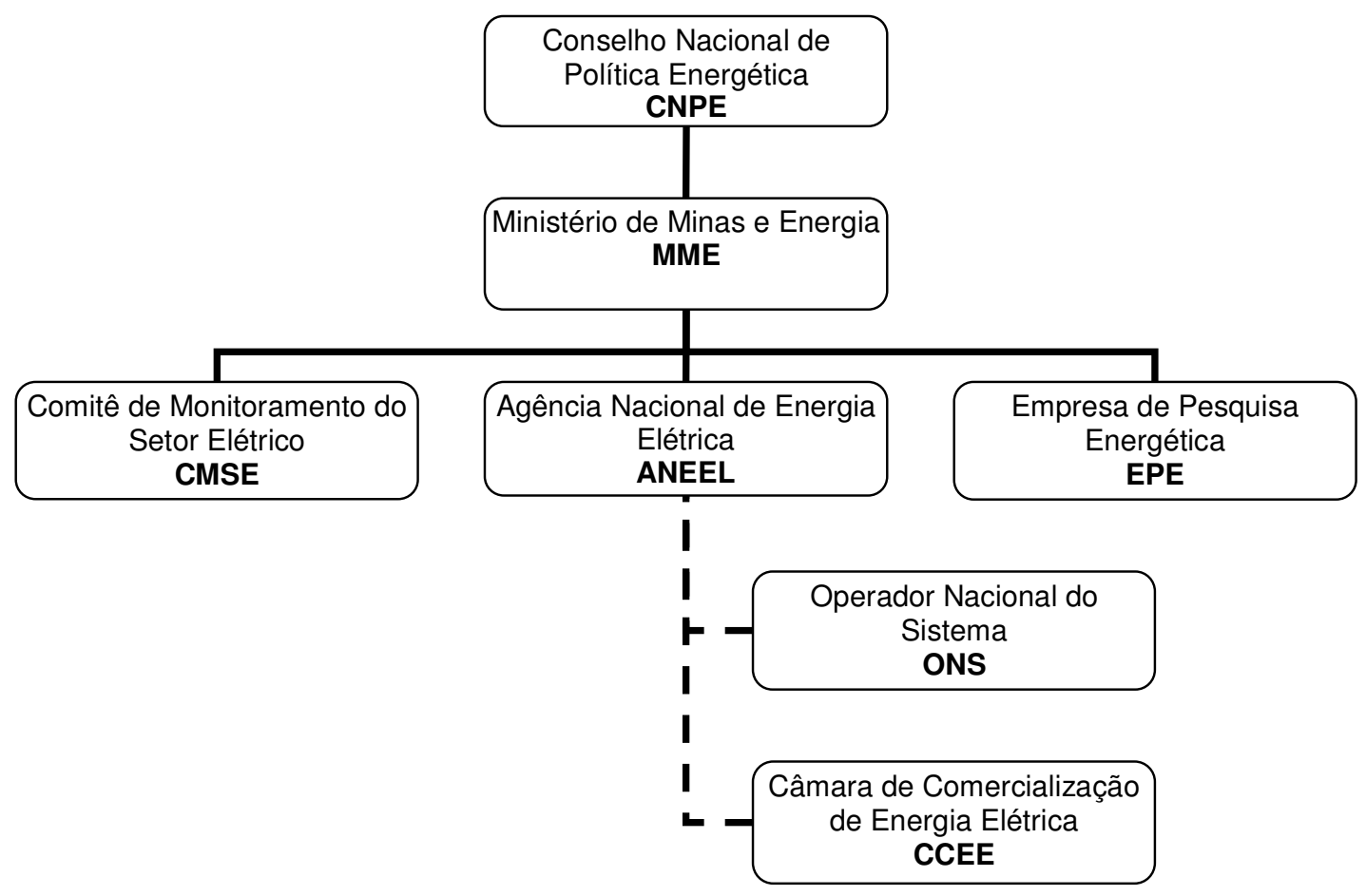

Figura 2 - Estrutura Organizacional Novo Modelo 


\section{A CÂMARA DE COMERCIALIZAÇÃO DE ENERGIA ELÉTRICA - CCEE}

Com a elaboração e implementação do Novo Modelo do Setor Elétrico, houve a necessidade da criação de um ambiente onde fossem realizadas todas as operações de contabilização e liquidação financeira que envolvesse o mercado de curto prazo. Com esse objetivo, foi criado em 1998 o Mercado Atacadista de Energia Elétrica - MAE. E para viabilizar as operações efetuadas nesse ambiente, foi criada a Administradora de Serviços do Mercado Atacadista de Energia Elétrica - ASMAE, uma entidade privada sem fins lucrativos, cujo principal objetivo era viabilizar as operações do mercado de curto prazo, referente à contabilização e liquidação financeira.

Posteriormente, em novembro de 2004, após um período em que funcionou em regime de intervenção da ANEEL, essa mesma entidade foi reformulada em suas funcionalidades e atribuições, recebendo uma nova denominação: Câmara de Comercialização de Energia Elétrica - CCEE, cujo nome persiste até os dias de hoje. Durante a transição do MAE para a CCEE, o Ministério de Minas e Energia reviu as principais atribuições da CCEE e, além de alterar a denominação, também alterou significativamente a forma de atuação dessa entidade, atribuindoa novas funções, como por exemplo, ser responsável pela sistemática dos leilões de energia nova que estavam por acontecer.

A participação na CCEE é facultativa para alguns agentes de mercado e obrigatória para outros. São obrigatórios os agentes de geração que possuem empreendimentos com capacidade superior a $50 \mathrm{MW}$, que possuam usinas despachadas centralizadamente pelo ONS, ou que tenham contratos de venda de energia elétrica a consumidores livres. Os agentes da categoria de distribuição com participação obrigatória no CCEE são aqueles que possuam um mercado maior ou igual a $500 \mathrm{GWh} /$ ano.

Também é obrigatória a participação na CCEE de consumidores que adquiram energia elétrica no ambiente livre - ACL. 
Os agentes de Transmissão não participam da Câmara de Comercialização de Energia Elétrica.

Aos demais agentes de mercado é facultativa a participação na CCEE.

\subsection{O MERCADO DE CURTO PRAZO}

O Mercado de Curto Prazo é o ambiente onde os agentes de mercado negociam, via contratos bilaterais livremente negociados, a compra ou venda de energia com o objetivo de "fecharem" o balanço energético de suas empresas, evitando assim exposições no mercado de curto prazo, com necessidade de liquidação da diferença entre valores medidos e compromissados em contrato, pelo mercado de curto prazo, buscando sempre evitar a aplicação de penalidades previstas na legislação vigente do setor, objetivando a maximização de lucros.

Ao se fazer a contratação de energia elétrica, o agente de mercado faz apenas uma estimativa do seu consumo, tendo em vista que a contratação é feita "exante". Dessa forma, pode existir uma diferença entre a energia contratada e a energia efetivamente consumida pelos agentes de mercado. Essa diferença deve ser apurada e liquidada no mercado de curto prazo, valorada ao Preço de Liquidação das Diferenças - PLD, que reflete o custo marginal de operação. $O$ PLD possui valores máximos e mínimos determinados pela ANEEL, e varia de acordo com o custo marginal de operação oriundo de simulação realizada em âmbito CCEE, com a mesma modelagem computacional e dados de natureza sistêmica que são empregados pelo ONS para definir o despacho das usinas.

A diferença entre as duas simulações, consiste na não utilização de informações de natureza conjuntural, como por exemplo a indisponibilidade de linhas de transmissão internas a um submercado, nas simulações destinadas à formação do preço "spot". 
Dessa forma, os agentes que tiverem um consumo menor do que efetivamente contrataram, receberão essa diferença valorada ao PLD. Da mesma maneira, o agente que consume um montante maior do que contratou, deve pagar a energia adicional valorada ao PLD.

Esse mecanismo de funcionamento permite aos agentes de mercado montar diversas estratégias de atuação no mercado livre dependendo de vários fatores, como por exemplo sazonalidade do PLD, previsão de afluências dos rios, nível de contratação das empresas, entre outros. A cada estratégia existe um risco associado, que pode ser maior ou menor dependendo dos fatores em questão. Via de regra, para um retorno maior, o risco é maior, e vice-versa.

Por exemplo: um agente de mercado fez a previsão de sua carga para o ano seguinte e, considerando que em suas análises havia a previsão de que no ano seguinte o preço de mercado estaria alto, a empresa resolveu contratar energia para esse mesmo ano pagando um valor $R \$ X, X X$ pela energia, minimizando assim o risco de exposição ao mercado de curto prazo em cenários de PLD alto. Caso a previsão se confirme e o PLD para o ano seguinte seja alto (acima de $R \$$ $X, X X)$, o agente acertou na sua decisão. No entanto, se o PLD for baixo, o agente poderia ter tomado outra decisão, pois a energia no mercado de curto prazo é mais barata do que a energia que foi contratada pelo agente no passado.

A figura a seguir ilustra o funcionamento básico do mercado de curto prazo, exemplificando a exposição de um agente por subcontratação. Nesse caso, se o PLD estiver abaixo do valor da energia contratada pelo agente, houve um ganho, pois o agente "completa" a sua necessidade com energia mais barata que a energia contratada por ele. Mas existem mecanismos que inibem ações desse tipo por parte dos agentes de mercado, sendo inclusive aplicadas penalidades para alguns tipos de comportamentos que vão de encontro com as premissas do modelo do setor elétrico vigente. 


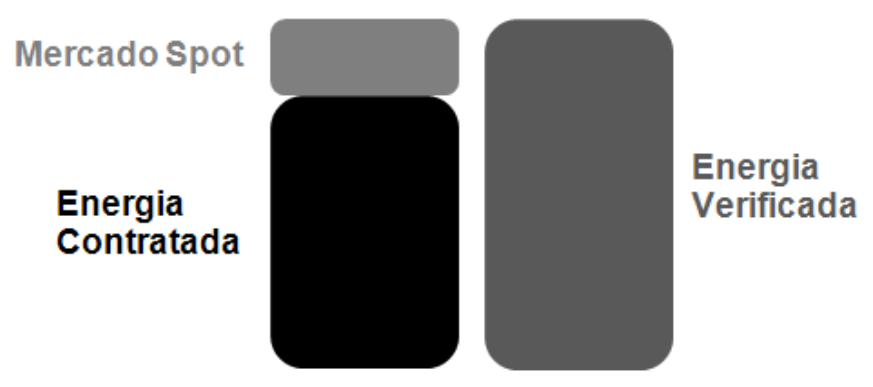

Fonte: CCEE, 2008

Figura 3 - Mercado de Curto Prazo

Todos os agentes de mercado participantes da CCEE estão sujeitos a contabilização e a liquidação financeira das diferenças. No entanto, a contratação promovida pelos agentes pode ser realizada em dois (2) ambientes distintos de contratação, dependendo da classe e categoria de cada agente. Esses ambientes de contratação possuem algumas regras e procedimentos em comum.

Uma das principais preocupações do órgão regulador do setor elétrico refere-se às estratégias que os agentes do setor podem fazer, vislumbrando maximizar os lucros de suas empresas. O problema é que muitas dessas estratégias dos agentes vão de encontro às premissas básicas do modelo do setor, como por exemplo, a modicidade tarifária.

Para evitar esse tipo de comportamento, existem algumas obrigatoriedades que os agentes devem cumprir, principalmente no que diz respeito ao nível de contratação. Existe uma série de penalidades que são aplicadas aos agentes que ficam expostos ao mercado de curto prazo, evitando assim comportamentos que fogem aos princípios básicos do modelo.

Para as empresas distribuidoras de energia, um dos principais mecanismos para evitar a exposição da empresa no mercado de curto prazo são os leilões de energia nova que ocorrem com cinco anos de antecedência. Nos capítulos seguintes serão descritos os principais tipos de leilões existentes, sendo que o de 
A-5 é aquele onde o agente de distribuição têm mais incentivos para contratar energia, evitando assim exposições no mercado de curto prazo e, consequentemente, aplicações de penalidades e otimizando o repasse dos custos de aquisição de energias às tarifas dos consumidores finais.

\subsection{OS AMBIENTES DE CONTRATAÇÃO}

Cada agente de mercado possui uma classe e uma categoria de atuação, autorizado pelo órgão regulador. A divisão entre classes e categorias de agentes pode ser visualizada abaixo:

Tabela 1 - Classe dos Agentes de Mercado

\begin{tabular}{|l|l|}
\hline \multicolumn{1}{|c|}{ Categoria } & \multicolumn{1}{c|}{ Classe } \\
\hline \multirow{2}{*}{ Geração } & Geradores \\
\cline { 2 - 2 } & Produtores Independentes \\
\cline { 2 - 2 } & Autoprodutores \\
\hline \multirow{2}{*}{ Distribuição } & Distribuidores \\
\cline { 2 - 2 } & Consumidores Livres \\
\hline \multirow{2}{*}{ Comercialização } & Comercializadores \\
\cline { 2 - 2 } & Importadores / Exportadores \\
\hline
\end{tabular}

Dependendo da categoria e classe do agente, ele pode atuar no Ambiente de Contratação Livre - ACL, no Ambiente de Contratação Regulada - ACR, ou em ambos, conforme ilustra a figura a seguir. 


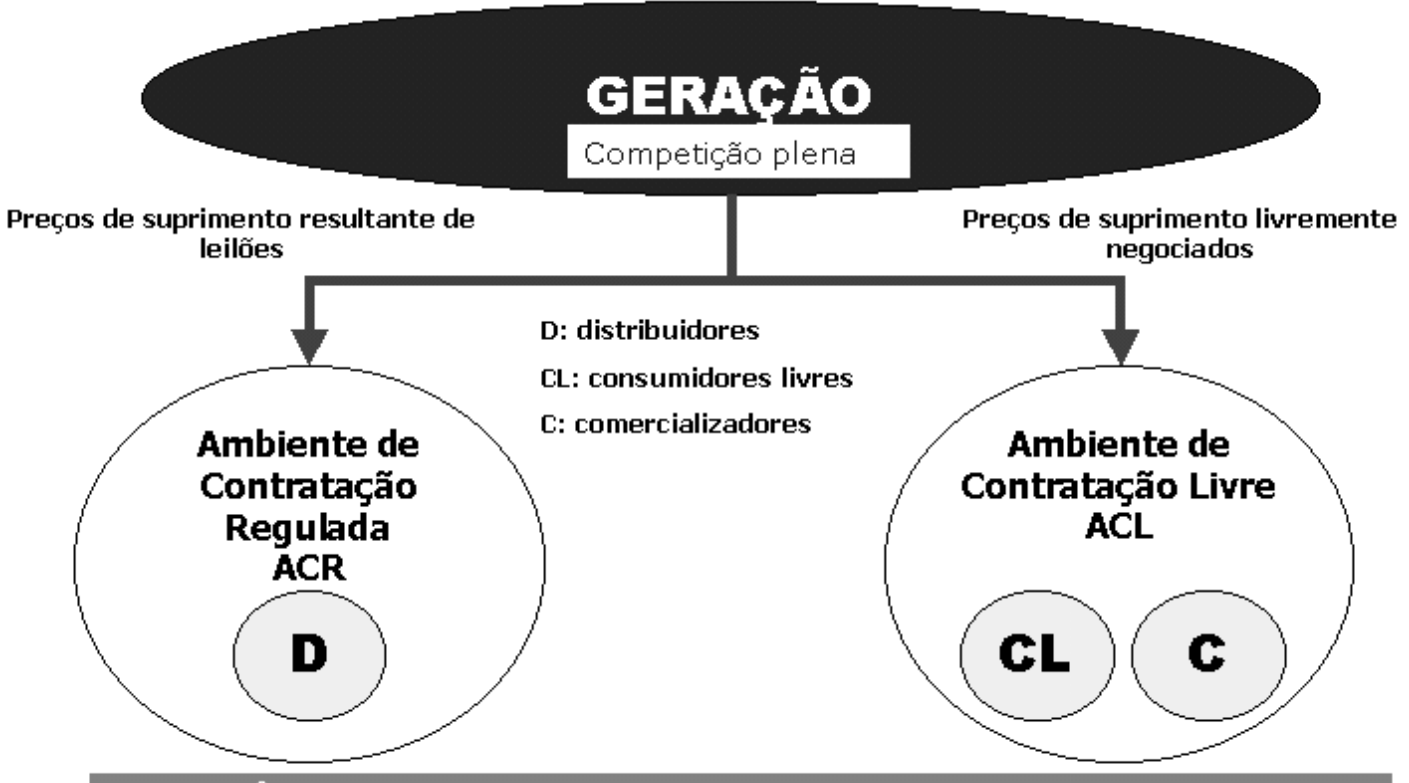

CONVIVÊNCIA ENTRE MERCADO COMPETITIVO E MERCADO REGULADO

Figura 4 - Ambientes de Contratação

Os agentes de geração podem participar tanto do ambiente de contratação regulada - ACR quanto do ambiente de contratação livre - ACL, sendo que a diferença mais significativa no que tange a comercialização de energia para 0 gerador diz respeito a maneira como o agente negocia a energia. No ACR o agente gerador pode vender energia somente a partir de leilões regulados de aquisição de energia, onde o preço de venda é resultante desses leilões. Já no $A C L ~ o$ agente gerador pode negociar livremente os preços e condições da venda de sua energia diretamente com o agente comprador.

Os agentes de distribuição podem atuar somente no ambiente regulado - ACR, onde os preços de compra de energia são os resultantes dos leilões regulados de aquisição de energia. Não existe a possibilidade do agente distribuidor atuar no ACL.

Por fim, os consumidores livres e comercializadores são agentes que podem atuar somente no ambiente de contratação livre - ACL, onde os preços e condições de compra e venda de energia são livremente negociados entre as partes. 
Dessa forma, existe uma convivência entre o mercado livre e o mercado regulado, com algumas regras e procedimentos distintos aplicados em um ou em outro ambiente de contratação.

\subsubsection{O Ambiente de Contratação Livre (ACL)}

No Ambiente de Contratação Livre podem operar os agentes da categoria geração, comercialização, e os agentes da classe Consumidores Livres.

Nesse ambiente, os contratos de compra e venda de energia elétrica são livremente negociados entre as partes, e homologados e registrados na ANEEL e na CCEE, respectivamente.

Atualmente, esse ambiente corresponde a cerca de $20 \%$ do mercado de energia brasileiro, segundo dados da CCEE. Existem regras específicas para atuação no ambiente de contratação livre do mercado de energia, sendo que não são necessariamente as mesmas regras utilizadas no ambiente de contratação regulada.

\subsubsection{O Ambiente de Contratação Regulada (ACR)}

No Ambiente de Contratação Regulada - ACR participam todas as distribuidoras de energia, como compradoras, além dos geradores como vendedores.

Nesse ambiente, a compra e venda de energia elétrica se dá através de Leilões de energia promovidos pela CCEE. As distribuidoras devem atender a totalidade 
de sua carga através desses leilões, e celebrar os Contratos de Compra e Venda de Energia Elétrica no Ambiente Regulado - CCEAR's, estando sujeita as penalidades previstas na legislação, caso isso não ocorra.

Os leilões são separados em novos empreendimentos e em empreendimentos existentes, com características diferenciadas para cada um deles, incluindo a duração dos contratos e o período de antecedência de contratação.

\subsection{OS DESAFIOS PARA AS CONCESSIONÁRIAS DE DISTRIBUIÇÃO}

No cenário atual do modelo do setor elétrico brasileiro, as empresas distribuidoras de energia têm um grande desafio pela frente no que diz respeito aos riscos de mercado. Com a reestruturação do setor elétrico, novos riscos foram agregados aos já existentes, tornando assim a análise de risco uma ferramenta fundamental para o sucesso ou fracasso de uma empresa no setor.

Dessa forma, as empresas criaram ferramentas que pudessem mensurar os riscos associados a cada decisão da empresa, tendo em vista os possíveis cenários de mercado.

De um modo geral, os riscos estão associados às perdas financeiras de uma eventual remuneração não adequada aos investimentos realizados. Dessa forma, é inevitável que os agentes do mercado de energia elétrica se utilizem de ferramentas e conceitos amplamente utilizados em outras áreas para mensurar os seus próprios riscos. À essa análise é dada a denominação de análise de risco, tarefa essa que vem ganhando espaço a cada dia que passa no mercado de energia elétrica.

Dessa forma, os agentes de mercado têm se utilizado principalmente dos seguintes conceitos na avaliação de riscos: 
- Volatilidade: é uma medida de variabilidade de comportamento da variável de interesse muito simples e muito usada, podendo ser definida simplesmente como o desvio padrão do valor do contrato ou carteira. Um dos problemas em adotar essa medida é que a distribuição do valor do contrato deve ser uma Curva Normal. Como na vida real essa distribuição nunca é Normal, a volatilidade fornece, segundo Veiga (1999), apenas uma aproximação para o nível de incerteza que se tem do valor do contrato. Quando essa distribuição não é conhecida, usa-se uma amostra de valores de contrato freqüentemente obtida de técnicas de computação intensiva e amostragens, entre elas a simulação Monte Carlo.

- Arrependimento Minimax: em geral, minimiza-se o máximo arrependimento relativo a cada cenário, sendo o arrependimento a cada cenário a diferença entre o custo real e aquele calculado para um determinado cenário, sabendo-se previamente que ele ocorrerá (de referência). Este critério é também muito utilizado em planejamento da expansão (Miranda \& Proença, 1998a, 1998b).

- Value at Risk (VaR): O conceito também é muito simples e representa o valor de risco mínimo que pode assumir um contrato ou carteira para um dado nível de probabilidade. Em outras palavras, é o valor monetário das perdas a que um contrato ou carteira está sujeita em um período de tempo, dado um determinado intervalo de confiança (Silva Neto, 2000). Por exemplo, se uma carteira tem um VaR de $R \$ 30.000$, em um determinado mês ou período, com um intervalo de confiança de $95 \%$, isto equivale dizer que há $5 \%$ de probabilidade da carteira perder mais de $R \$ 30.000$ nesse mês. Um dos problemas identificados por Veiga (1999) nesse tipo de medida de risco é que raramente são observados valores abaixo do valor da probabilidade associada, o que faz com que sua estimação seja imprecisa.

A utilização desses conceitos de risco deve ser trazida para o ambiente do setor elétrico, onde existem alguns riscos associados, nesse caso, às empresas de 
distribuição de energia. Basicamente, existem três (3) tipos de riscos a qual a distribuidora está sujeita: Risco de Mercado, Risco da Receita e Risco de Abastecimento. A seguir serão detalhados cada um desses riscos.

\subsubsection{Risco de Mercado}

O risco de mercado é o principal tipo de risco a que uma empresa distribuidora está sujeita, sendo que a mitigação desse tipo de risco está basicamente associada à estratégia e utilização dos mecanismos de mitigação que a mesma pode se utilizar.

No novo modelo do setor elétrico, existem alguns mecanismos de mitigação de riscos, que serão descritos em capítulos adiantes, que podem minimizar o risco de mercado das distribuidoras, bem como existem outros mecanismos de mitigação de riscos para os demais agentes do setor (geradores, consumidores livres, etc).

Basicamente, o risco de mercado de um agente de distribuição é composto de alguns itens, e o principal deles está associado à contratação antecipada em leilões, cujos contratos são de longa duração. Se as distribuidoras contratarem abaixo do seu mercado declarado, existem alguns mecanismos de ajustes que minimizam esse risco. Por outro lado, se ocorrer a sobrecontratação, acima de determinado patamar, o risco de mercado é assumido integralmente pela distribuidora, uma vez que existe limitação para o repasse dos custos de aquisição de energia aos consumidores finais, bem como para a transferência para outros agentes geradores existentes.

É a eficiência na contratação dos leilões de Energia Nova ou A-5, que podem melhorar ou piorar consideravelmente a saúde financeira da distribuidora. 
Outro importante risco de mercado refere-se a transmissão de energia entre submercados devido a eventual necessidade de abastecimento emergencial de uma região por outra onde a oferta de energia é abundante naquele momento. Esse risco é integralmente assumido pela distribuidora e transferido para os consumidores cativos, via repasse às tarifas.

Ainda nessa mesma linha, existe o risco hidrológico onde, para um sistema hidrotérmico predominantemente hidráulico como o brasileiro, é natural que os principais fatores de riscos, relacionados à oferta, sejam decorrentes da hidrologia. As vazões afluentes aos reservatórios geralmente possuem uma marcante componente sazonal, embora sejam fontes de grande variabilidade e volatilidade. Essa grande variabilidade e volatilidade dos reservatórios, associado a sazonalidade das vazões afluentes, faz com que esse risco, assumido pelos agentes geradores, tenha uma relevância significativa na avaliação de risco de mercado.

Além disso, existe o risco de exposição ao PLD devido a frustração dos Leilões, ou seja, quando existe uma demanda declarada e não contratada. No caso de elevação do PLD, a exposição da distribuidora ao mercado de curto prazo pode comprometer todo um planejamento financeiro realizado anteriormente.

Por fim, existe o risco da saída de consumidores potencialmente livres, onde a distribuidora pode mitigar o seu risco reduzindo integralmente esse montante dos CCEAR's de energia existente.

\subsubsection{Risco da Receita}

O risco de receita é uma questão muito complexa, pois esse parâmetro está associada a fatores exógenos ao mercado de energia elétrica, mas impacta diretamente no bom funcionamento do mesmo, pois é a receita das distribuidoras 
que garantem todos os investimentos do setor (geração, transmissão e distribuição). Em outras palavras, são os consumidores que garantem a expansão do setor elétrico, sendo que $80 \%$ dos consumidores são cativos. Nessa perspectiva, um alto risco de receita por parte da distribuidora pode iniciar uma reação em cadeia que levará consigo dificuldades financeiras à todos os agentes do setor.

Em linhas gerais, o risco de mercado está associado a dois (2) fatores principais: incide de perdas de energia elétrica e índice de inadimplência.

O índice de perdas de energia elétrica se divide em perdas técnicas e perdas nãotécnicas. As perdas técnicas estão associadas às perdas que ocorrem no processo de transmissão e distribuição de energia elétrica, uma vez que nesses processos a energia elétrica percorre cabos e outros equipamentos que possuem uma certa resistência característica, gerando assim perdas nesses equipamentos. Se a empresa fizer um bom planejamento e tiver boa saúde financeira, existe a possibilidade de que alguns desses equipamentos menos eficiente em termos de perda sejam substituídos por equipamentos mais eficientes, diminuindo assim 0 nível de perdas técnicas da empresa.

Já o índice de perdas não técnicas está associado a todo tipo de perda que não sejam àquelas descritas acima (perdas técnicas). A componente básica desse tipo de perda é o furto de energia, o popularmente conhecido "gato". A distribuidora tem uma certa gestão sobre isso, no entanto, a diminuição desse tipo de perda é de extrema dificuldade para as empresas, pois são fatores que vão além da questão energética. Existem locais onde sabidamente são realizados furtos de energia, mas que a concessionária não consegue acessar devido a ameaças de moradores aos funcionários das empresas. Além disso, existe a questão financeira, pois muitos cidadãos partem para esse tipo de atividade pois não tem condições de pagar a conta de luz.

Nessa mesma linha de raciocínio, está o risco de inadimplência. Existem fatores sociais que geram inadimplência dos consumidores junto à distribuidora. Da 
mesma maneira, existem alguns fatores, como a elevação de encargos e tributos setoriais, que refletem na tarifa de energia elétrica, elevando o valor a ser pago pelo consumidor final que, por motivos sociais, não tem condições de honrar com as suas contas e conseqüentemente fica inadimplente junto à concessionária. Por outro lado, existe um alto índice de inadimplência dos setores públicos junto às distribuidoras de energia, como pode ser observado na figura a seguir.

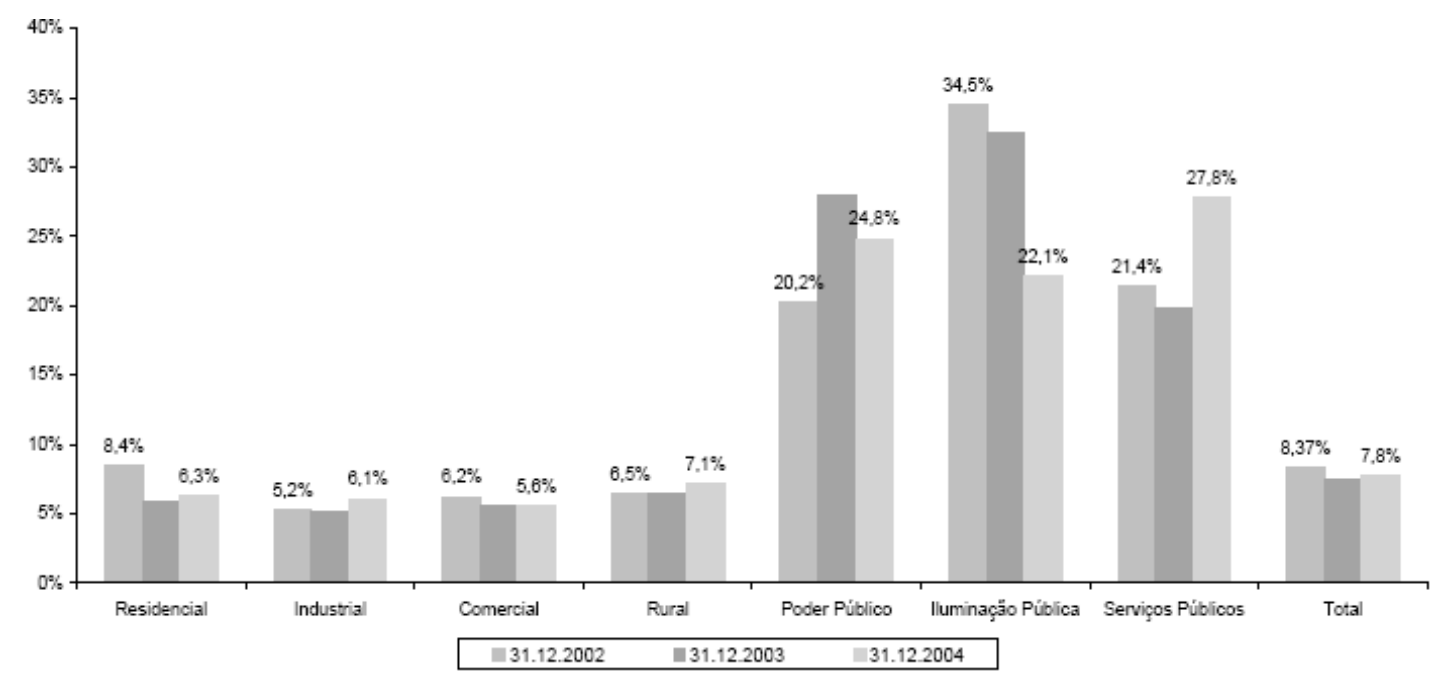

Fonte: MAIA, 2005

Figura 5 - Nível de Inadimplência por Classe de Consumo

Isso pode ser explicado basicamente pelo motivo já exposto referente aos encargos e tributos setoriais, além do histórico de má administração pública.

\subsubsection{Risco de Abastecimento}

Por fim, mas não menos importante, existe o risco de abastecimento. Pelo modelo do setor elétrico vigente atualmente, tanto distribuidoras quanto consumidores livres devem apresentar lastro físico para todos os seus contratos, além de ter 
que contratar $100 \%$ de sua demanda. No entanto, apenas as distribuidoras são obrigadas a contratar energia nos leilões de A-5 (com antecedência de 5 anos) que, como será visto adiante, são os principais responsáveis pela expansão da oferta de energia no país. Se levarmos em conta que atualmente os consumidores livres representam $20 \%$ do mercado de energia, com tendência de crescimento, fica fácil concluir que, sem o devido incentivo, os mesmos não farão contratação de energia para atendimento de sua carga com uma antecedência tão grande a ponto de garantir a expansão da oferta no país, pois esses consumidores podem deixar para contratar na última hora, aproveitando-se de melhores condições de preço decorrentes de uma eventual conjuntura de sobreoferta.

Diante desse cenário, fica claro que a garantia de suprimento de energia está comprometida para os próximos anos, tendo em vista que a curva de oferta e demanda de energia se aproximam, e que a participação de consumidores livres no mercado aumenta gradativamente.

A conseqüência desses fatores pode ser um novo racionamento de energia, caso não sejam tomadas medidas emergenciais no que tange o abastecimento de energia.

Somente para exemplificar, o risco de abastecimento é iminente, e a prova disso é que no mês de janeiro de 2008, o PLD semanal atingiu o seu valor máximo $(R \$$ 569,69 / MWh), fato esse que não ocorria desde o racionamento de 2001. 


\section{LEILÕES REGULADOS PARA AQUISIÇÃO DE ENERGIA ELÉTRICA}

Como descrito no capítulo anterior, as distribuidoras podem contratar energia elétrica somente através de leilões, sejam eles de energia existente ou de energia nova.

Energia existente caracteriza a energia oriunda de empreendimentos já construídos, que ainda não contrataram a totalidade da sua energia. Energia nova entende-se por energia oriunda de empreendimentos que ainda serão construídos.

Existem vários tipos de leilões que são realizados periodicamente pelo governo federal, cuja operacionalização é de responsabilidade da CCEE, com o objetivo de atender a demanda das distribuidoras, e conseqüentemente promover a expansão da oferta de energia no país, uma vez que as distribuidoras devem atender a totalidade da sua carga através da contratação via leilões de energia.

A seguir serão descritos os tipos de leilões existentes, bem como as suas principais características.

\subsection{LEILÕES DE ENERGIA EXISTENTE}

Os leilões de energia existente caracterizam-se por negociar energia somente de empreendimentos já construídos cuja energia não está totalmente contratada.

Esses leilões são realizados anualmente e caracterizam-se por negociar um montante de energia menor do que os leilões de energia nova. Isso acontece devido ao estímulo regulatório para que as distribuidoras façam uma contratação eficiente no leilão de energia nova, proporcionando assim a expansão da oferta 
de energia. São realizados sempre um ano antes do início do suprimento. Por esse motivo, os preços negociados no leilão de energia existente normalmente são menores do que os preços negociados nos leilões de energia nova.

Dessa forma, os leilões de energia existente A-1 são caracterizados por negociar energia para suprir a base do mercado de energia, fazendo com que as distribuidoras tenham que recorrer a esses leilões praticamente todos os anos.

Nessa modalidade de leilão são ofertadas energias de vários tipos de fontes (hidráulica, térmica, etc.)

Com a transição do Novo para o Novíssimo modelo do setor elétrico, houve uma significativa alteração na forma de contratação de energia por parte das distribuidoras do setor. Para superar esse período de transição, o governo federal, com a operacionalização da CCEE, realizou um leilão de energia existente onde todas as empresas distribuidoras de energia foram induzidas a participar e atender a sua demanda prevista para os próximos anos, tendo em vista a nova legislação do setor que previa algumas penalidades às empresas que ficassem com uma parcela de seu mercado descontratada. Esse leilão ocorreu no final de 2004 e previa a contratação de energia para os anos de 2005, 2006 e 2007.

Antes dessa nova regulamentação, as empresas distribuidoras de energia tinham a sua contratação de energia realizada através de contratos inicias, que eram contratos antigos, de longo prazo, que se encerrariam no final de 2004. Por esse motivo, quase que a totalidade das distribuidoras do setor teriam que contratar energia para atendimento da maior parte do seu mercado para os anos seguintes. Dessa forma, esse leilão negociou um montante tão grande de energia que na época os analistas o chamavam de "Mega Leilão". Em termos financeiros, foram negociados algo em torno de $\mathrm{R} \$ 75$ bilhões.

Devido às características acima descritas, bem como tendo em vista que os empreendimentos existentes que participaram como vendedores nesse leilão de 2004 tiveram que se submeter a uma forte competição entre si, visto que havia uma sobra de energia sistêmica da ordem de $6.000 \mathrm{MW}$ médios na época, o 
preço negociado ficou bem abaixo dos preços negociados nos leilões de energia existente atuais. Na época, o preço médio de venda de energia para as distribuidoras ficou em torno de $\mathrm{R} \$ 66,77$ / MWh (média dos preços médios dos 3 produtos negociados no leilão), enquanto que atualmente esse valor gira em torno de $\mathrm{R} \$ 104,74$ / MWh (referente ao preço médio do 5ำ leilão de energia existente), segundo dados da CCEE.

\subsection{LEILÕES DE ENERGIA NOVA}

Os leilões de Energia Nova são os responsáveis pela expansão da oferta de energia no novo modelo do setor. Esse fato somente é possível, pois existe um estímulo à contratação eficiente nesse tipo de leilão. Em linhas gerais, esse estímulo está associado ao fato de que a contratação de energia pelas distribuidoras nos leilões de energia nova tem um "custo" associado menor do que nos outros leilões, sendo que o repasse dos custos dessa aquisição aos consumidores finais está diretamente ligado a modicidade tarifária.

Sendo assim, o distribuidor se vê estimulado a contratar energia nessa modalidade de leilão, garantindo assim a expansão da oferta.

Desse leilão, podem participar empreendimentos dos mais variados tipos de fonte, como hidráulica, térmica a óleo, carvão mineral e biomassa, entre outros. São empreendimentos que já possuem a Licença Prévia de Instalação, emitida pela EPE, e que ainda não iniciaram a sua construção.

Esses leilões são realizados regularmente pela ANEEL, sob orientação do MME, com outorga simultânea de concessão para empreendimentos hidroelétricos, na modalidade "menor preço de venda", sagrando-se vencedor o proponente que oferecer o menor preço de venda pela construção do empreendimento. 
Esses preços podem ser entendidos como uma aproximação do Custo Marginal de Expansão, ou seja, o custo para se "injetar" um (1) MWh a mais no sistema.

Recentemente foi realizado 0 1ำ leilão de fontes alternativas, também caracterizado como leilão de energia nova. No entanto, o processo de leilão obedeceu uma sistemática bem diferenciada dos leilões convencionais de energia nova, além da diferenciação principal que seria o tipo de energia a ser negociada no leilão (energia oriunda de fontes alternativas).

\subsection{LEILÕES DE ENERGIA "BOTOX"}

$\mathrm{Na}$ transição do antigo para o novo modelo do setor elétrico, foi realizado o Mega Leilão de energia existente, do qual poderiam participar somente empreendimentos já construídos, cujos contratos de energia estavam vencendo ou já se encontravam vencidos naquele ano, o que acontecia com a maior parte dos empreendimentos, devido ao término dos contratos iniciais de energia.

No entanto, havia um grupo de empreendimentos que já haviam sido construídos, mas a energia gerada por eles ainda não havia sido contratada. A esse grupo de empreendimentos foi dada a opção de participar no leilão de energia nova ou no leilão de energia existente.

Evidentemente, o empreendimento que optasse por participar do leilão de energia existente não poderia participar do leilão de energia nova, e vice-versa.

A partir disso, os proprietários de empreendimentos que se caracterizavam como empreendimentos "Botox" fizeram suas análises para optar em qual dos leilões

\footnotetext{
${ }^{3}$ O termo energia "Botox" foi criado pelo grupo responsável pela reestruturação do setor elétrico brasileiro ao referir-se à "energia velha com cara de nova", ou seja, energia existente que ainda não havia sido contratada, fazendo alusão a substância Toxina Botulínica (BOTOX) amplamente utilizada no tratamento de correções de expressão devido ao envelhecimento facial.
} 
iriam negociar energia. Dessa forma, havia um dilema: os empreendimentos que optassem por participar do leilão de energia existente competiriam com empreendimentos cuja tarifa era mais baixa do que no leilão de energia nova. Por outro lado, havia o risco das distribuidoras contratarem a totalidade da sua necessidade e esse tipo de empreendimento continuaria sem contratar energia, ficando com uma grande parcela de seu empreendimento com energia descontratada.

O resultado foi que a maioria desses empreendimentos optou por participar do leilão de energia nova, sendo que conseguiram contratar quase que a totalidade de sua disponibilidade de energia.

\subsection{LEILÕES DE AJUSTE}

Os leilões de ajuste podem ser também caracterizados como leilões de energia existente, uma vez que o início de suprimento de energia até quatro (4) meses após a realização do leilão.

Eles são realizados para que as distribuidoras ajustem a sua contratação em função da volatilidade e da sazonalidade do seu mercado.

Nesse leilões também podem ser negociadas energia provenientes dos mais diversos tipos de fonte, como hidráulicas, térmicas, etc. 


\subsection{LEILÕES PARA AQUISIÇÃO DE ENERGIA DISTRIBUÍDA}

Uma outra forma que as distribuidoras tem para aquisição de energia elétrica é promover um leilão de energia elétrica oriunda de empreendimentos de geração distribuída. A realização desse leilão deve ser precedida de chamada pública, para garantir a publicidade, transparência e igualdade de acesso aos interessados.

Conforme descrito no Decreto nํ5163, de 30 de Julho de 2004, em seu artigo 14, "considera-se geração distribuída a produção de energia elétrica proveniente de empreendimentos de agentes concessionários, permissionários ou autorizados, incluindo aqueles tratados pelo art. 8 da Lei no 9074, de 1995, conectados diretamente no sistema elétrico de distribuição do comprador, exceto aquela proveniente de empreendimento:

I - hidrelétrico com capacidade instalada superior a $30 \mathrm{MW}$; e

II - termelétrico, inclusive de cogeração, com eficiência energética inferior a setenta e cinco por cento, conforme regulação da ANEEL, a ser estabelecida até dezembro de 2004."

No entanto, essa contratação está limitada a 10\% da carga da distribuidora, tomando como base os últimos 12 meses.

Associados a cada um dos leilões regulados para aquisição de energia elétrica existem riscos de volume e riscos de preço.

Os riscos de volume referem-se ao montante de energia que a distribuidora pode contratar em cada tipo de leilão de aquisição de energia. Esses limites foram estabelecidos pelo órgão regulador quando da introdução desses mecanismos de contratação no novo modelo do setor elétrico. Caso o agente de mercado ultrapasse esses limites, estará sujeito às penalidades previstas na legislação vigentes.

Já os riscos de preço referem-se especificamente aos limites de repasse às tarifas dos consumidores finais de energia dos custos de aquisição de energia elétrica nos leilões regulados para aquisição da mesma. Na prática, isso quer 
dizer que nem todo custo referente à aquisição de energia será inteiramente repassado às tarifas dos consumidores finais de energia. Isso é um mecanismo que foi introduzido no novo modelo do setor elétrico, com o objetivo de incentivar o agente de distribuição a gerir a sua empresa de maneira eficiente, pois a ineficiência será "punida" com limitações de repasse de custos.

Essa é a chamada regulação por incentivo, onde o órgão regulador incentiva o agente de distribuição a traçar estratégias eficientes de contratação de energia no que tange ao volume de energia, bem como repasse dos custos de aquisição da mesma às tarifas dos consumidores finais.

Adiante será apresentado um quadro que contempla os riscos de volume e os risco de preço de cada um dos tipos de leilões regulados para aquisição de energia elétrica. 


\section{MECANISMOS DE MITIGAÇÃO DE RISCOS DE MERCADO DAS DISTRIBUIDORAS}

O Novíssimo Modelo do setor elétrico introduziu a figura do Ambiente de Contratação Regulada (ACR), ambiente em que todas as distribuidoras de energia são obrigadas a adquirir sua energia. Conforme descrito no Artigo 11 do Decreto 5.163, de 30 de Julho de 2004

\footnotetext{
"Para atendimento à obrigação prevista no inciso II do art. $2^{\circ}$, cada agente de distribuição do SIN deverá adquirir, por meio de leilões realizados no ACR, energia elétrica proveniente de:

I - empreendimentos de geração existentes; e

II - novos empreendimentos de geração......"
}

Além da aquisição de energia em leilões, a legislação vigente prevê outros mecanismos que a distribuidora pode se utilizar para a contratação e gestão eficiente da empresa, tendo em vista que o repasse dos custos de aquisição de energia às tarifas dos consumidores finais está diretamente ligado a eficiência da empresa.

Os mecanismos que a distribuidora pode se utilizar na contratação de energia são:

- Participação em Leilões de Energia Nova A-5;

- Participação em Leilões de Energia Nova A-3

- Participação em Leilões de Energia Existente A-1

- Participação em Leilões de Ajuste;

- Aquisição de Energia Proveniente de Geração Distribuída;

- Redução de Contratos por Saídas de Consumidores Livres; 
- Redução de Contratos por Variação de Mercado;

- Mecanismo de Compensação de Sobras e Déficits.

No entanto, alguns desses mecanismos podem ser considerados mais efetivos como mecanismos de mitigação de riscos de mercado das distribuidoras. Isso porque a legislação vigente e os preços de mercado limitam essa utilização como mecanismo de mitigação de risco.

Dentre os mecanismos acima descritos, todos podem ser considerados na análise de mitigação de riscos de mercado por parte das distribuidoras, exceto um (1) deles: Participação em Leilões de Energia Nova A-5.

A participação em Leilões de Energia Nova A-5 não pode ser considerada como mecanismo de mitigação de risco de mercado porque pela legislação vigente, existe a obrigatoriedade da contratação de $100 \%$ da sua demanda declarada por parte das distribuidoras. Sendo assim, esse mecanismo deixa de ser um mecanismo de mitigação de risco para ser uma obrigatoriedade a ser observada pelo agente de distribuição.

Além do mecanismo citado no parágrafo anterior, a participação em leilões de energia existente de A-1 é um mecanismo de mitigação de risco de mercado que não foi considerado como mecanismo de mitigação somente na transição do modelo, ou seja, no primeiro momento de contratação das distribuidoras, fato ocorrido no final de 2004 (1ํleilão de energia existente).

Dessa forma, serão descritos a seguir os mecanismos de mitigação de riscos de mercado disponíveis para utilização por parte das distribuidoras, decorrentes da contratação de energia realizada pelas mesmas nos leilões de energia nova A-5. 


\subsection{PARTICIPAÇÃO EM LEILÕES DE ENERGIA NOVA A-3}

Os leilões de Energia Nova A-3 são muito parecidos com os leilões de A-5. No entanto, o início de suprimento previsto é de três (3) anos a partir da data de realização do leilão, enquanto que nos leilões de A-5 o início de suprimento é de cinco (5) anos a partir da data de realização do leilão.

Além disso, o custo associado a esse tipo de leilão é maior do que o leilão de A-5, devido a participação predominante de empreendimentos termoelétricos nessa modalidade de leilão. Isso porque o processo de construção de em empreendimento hidroelétrico é bem mais demorado do que o processo de construção de um empreendimento termoelétrico, ambos de mesmo porte. Essa maior demora acontece por vários fatores, como obtenção de licenças ambientais, distância do centro de consumo, necessidade de construção de longas linhas de transmissão e de barragens, entre outros fatores.

A participação em leilões de A-3 é o primeiro mecanismo que a empresa distribuidora tem para mitigar os riscos de mercado que envolve a contratação de energia, pois os custos são maiores que nos leilões de $A-5$, mas menores do que nos leilões cuja data de realização seja mais próxima da data de início de suprimento.

A realização desses leilões são regulares, e caracterizados pela participação predominante de empreendimentos termoelétricos, conforme já explicitado, devido ao início de suprimento ser apenas três (3) anos após a realização do mesmo.

O prazo do contrato celebrado nessa modalidade é de 15 a 30 anos, dependendo do tipo de fonte do empreendimento, e o limite de volume de contratação é de até $2 \%$ da carga da distribuidora declarada quando da realização do leilão de A-5. 
Quanto ao repasse tarifário dos custos de aquisição de energia nessa modalidade de leilão, nos primeiros 3 anos do contrato o repasse é limitado ao Valor de Referência - VR, e nos anos seguintes o repasse é integral, sendo que em caso de contratação excedente o repasse é limitado ao menor valor entre o preço negociado no A-5 e no A-3.

\subsection{PARTICIPAÇÃO EM LEILÕES DE ENERGIA EXISTENTE A-1}

Os leilões de energia existente A-1 diferem dos anteriores por se tratar de energia oriunda de empreendimentos já construídos, porém com uma parcela, ou a totalidade da sua energia descontratada.

Esse tipo de leilão não garante a expansão do sistema e são utilizados pelas distribuidoras apenas para suprirem alguma variação do mercado. Além disso, existe um limite de contratação para esse tipo de leilão: cada distribuidora pode contratar até $105 \%$ dos contratos que estejam vencendo no ano de realização do leilão.

A principal característica que define os leilões de energia existente A-1 como mecanismo de mitigação de riscos de mercado das distribuidoras é o fato de que permite contratar uma diferença maior do que a reposição, além de permitir a redução da contratação.

Dessa forma, esse mecanismo de mitigação é utilizado com bastante freqüência pelas distribuidoras, porém negociando volumes de energia menores.

O prazo do contrato celebrado nessa modalidade é de 5 a 15 anos, dependendo do tipo de fonte do empreendimento, e o limite de volume de contratação é de até $1 \%$ da carga da distribuidora em A-2 no momento, podendo evoluir para os $5 \%$ adicionais citados no futuro. 
Quanto ao repasse tarifário dos custos de aquisição de energia nessa modalidade de leilão, é integral se respeitado o limite de $1 \%$ do volume de contratação. Acima disso, o repasse é de $70 \%$ do preço.

\subsection{PARTICIPAÇÃO EM LEILÕES DE AJUSTE}

Os leilões de ajuste são leilões realizados basicamente para atender as variações de mercado, sendo que as distribuidoras de energia se utilizam muito desse mecanismo nos casos em que a variação de mercado é identificada somente "em cima da hora".

Para exemplificar a utilização dos leilões de ajuste como mecanismo de mitigação de risco, vamos descrever a seguinte situação: uma distribuidora declarou um determinado valor de mercado de sua carga e com a volta de alguns consumidores a condição de cativo, existe a necessidade de contratar mais energia para atendê-los.

Essa situação é perfeitamente possível, pois existe um grupo de consumidores, denominado Consumidor Especial, que pode exercer a opção de compra de energia no mercado livre a partir de fontes incentivadas de energia, sendo que 0 requisito básico exigido do consumidor é que sua demanda seja maior que 0,5 MW e menor que 3,0 MW. Para esse grupo de consumidores, o retorno ao mercado cativo pode ocorrer num prazo máximo de seis (6) meses a partir da data de declaração, à distribuidora, de intenção de retorno ao mercado cativo.

Nessa situação, pode ser que, devido ao aumento de demanda inesperado, a distribuidora não tenha energia suficiente para atender a esse consumidor que exerceu o seu direito de retorno ao mercado cativo num prazo máximo de seis (6) meses, contratando assim energia no leilão de ajuste, pois o início de suprimento desses leilões é de quatro (4) meses após a realização do mesmo. 
Há que se ressaltar que, atualmente, o limite para contratação de energia nos leilões de ajuste é de $1 \%$ da demanda contratada da distribuidora, evitando assim que deixem de contratar energia de empreendimentos novos para contratar energia de empreendimentos existentes. No entanto, a legislação prevê que esse limite pode ser de até $5 \%$ da demanda contratada da distribuidora, dependendo da situação conjuntural sistêmica, sendo que esse limite somente pode ser alterado pelo MME, através de Decreto.

O prazo do contrato celebrado nessa modalidade é de até 2 anos, e o limite de volume de contratação é de até $1 \%$ da carga da distribuidora no ano A.

Quanto ao repasse tarifário dos custos de aquisição de energia nessa modalidade de leilão, é limitado ao Valor de Referência - VR.

\subsection{AQUISIÇÃO DE ENERGIA PROVENIENTE DE GERAÇÃO DISTRIBUÍDA}

A distribuidora pode também mitigar os seus riscos de mercado através da aquisição de energia oriunda de empreendimentos de geração distribuída. Geração distribuída entende-se como a produção de energia elétrica de empreendimentos conectados diretamente ao sistema de distribuição do agente comprador.

Para adquirir energia distribuída, a distribuidora deve promover uma chamada pública, garantindo a transparência e a isonomia no processo. No entanto, existe um limite para aquisição desse tipo de energia que é de $10 \%$ do mercado verificado da distribuidora, com base nos últimos 12 meses.

Quanto ao repasse tarifário dos custos de aquisição de energia nessa modalidade de leilão, é limitado ao Valor de Referência - VR. 


\subsection{REDUÇÃO DE CONTRATOS POR SAÍDA DE CONSUMIDORES LIVRES}

Pela nova legislação do setor elétrico, a distribuidora deve declarar o seu mercado para participação nos leilões de energia nova, segregando inclusive os montantes contratados com consumidores potencialmente livres. Esses consumidores são aqueles que possuem as premissas básicas para se tornarem livres, mas que ainda não o fizeram.

Assim que um desses consumidores potencialmente livres exerce o seu direito de se tornar livre, a distribuidora pode reduzir os seus contratos em função dessa saída, sem qualquer ônus.

É por isso que a identificação dos potenciais consumidores livres na área de concessão da distribuidora é de vital importância para a saúde financeira da mesma, seja para mantê-lo como consumidor cativo, seja para solicitar a redução do seu contrato quando da saída para o mercado livre.

\subsection{REDUÇÃO DE CONTRATOS POR VARIAÇÃO DE MERCADO}

Além dos mecanismos apresentados anteriormente, a distribuidora ainda pode reduzir em até $4 \%$ ao ano os contratos de energia existentes, a seu critério, independentemente das reduções efetuadas em anos anteriores ou através dos mecanismos descritos anteriormente.

Essa redução possibilita a distribuidora uma certa "proteção" às variações de mercado. Essas variações de mercado estão sujeitas principalmente ao 
crescimento da economia e a mudança de comportamento dos consumidores. Como exemplo, vale lembrar o fato ocorrido com o racionamento de energia de 2001, quando houve uma pressão por parte do governo para a redução do consumo de energia por parte dos consumidores, sendo que esses acabaram reduzindo-o através de mudanças de hábito e comportamento, adquirindo equipamentos mais eficientes, como também utilizando a energia de forma mais eficiente, entre outras medidas.

Para se proteger desse tipo de variação, as distribuidoras tem a possibilidade de efetuar a redução descrita anteriormente.

É importante ressaltar que a redução permitida é de $4 \%$ ao ano, independentemente da redução exercida pela distribuidora no ano anterior. Ou seja, se num determinado ano a distribuidora exerceu redução de $3 \%$, no ano seguinte o valor máximo que ela pode reduzir é de $4 \%$, e não $5 \%$. A figura a seguir ilustra essa situação.

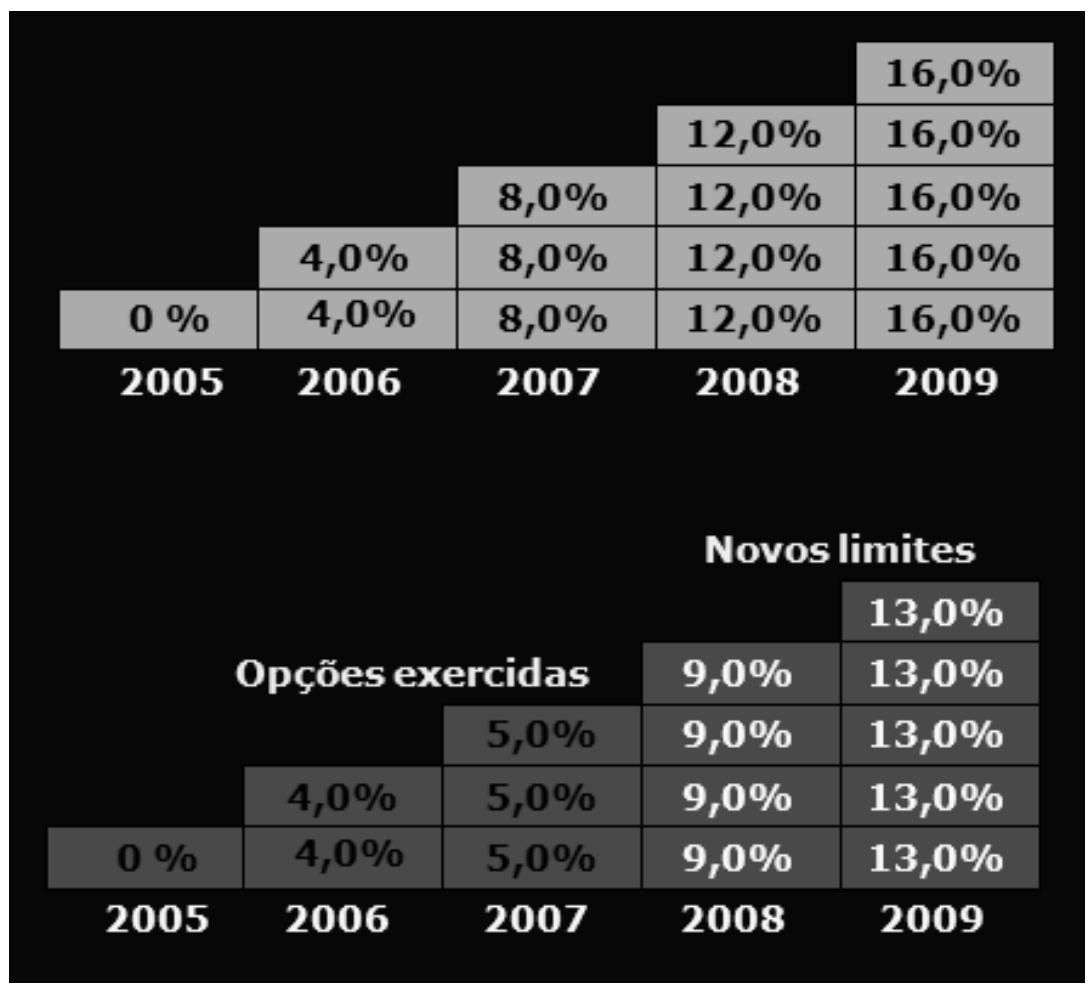

Figura 6 - Redução de Contratos por Variação de Mercado (Percentuais acumulados) 


\subsection{MECANISMO DE COMPENSAÇÃO DE SOBRAS E DÉFICITS (MCSD)}

O Decreto o 5.163 de 2004, em seu artigo 29 define que os CCEAR's oriundos de leilões de energia de empreendimentos existentes devem prever a possibilidade de redução e compensação dos montantes contratados através da aplicação do Mecanismo de Compensação de Sobras e Déficits (MCSD).

O Mecanismo de Compensação de Sobras e Déficits - MCSD foi criado com o objetivo de transferir a energia excedente de um agente distribuidor para outro agente distribuidor que esteja com déficit de energia.

Esse mecanismo é executado pela CCEE antes de qualquer outro mecanismo de redução, de tal forma que as empresas possam "trocar" energia e os agentes geradores não sofreriam qualquer tipo de prejuízo.

Dessa forma, as sobras de energia dos agentes distribuidores seriam "cedidas" aos agentes deficitários, mediante assinaturas de termos de cessão. De maneira análoga, a compensação de sobras e déficits é realizada também entre os agentes geradores do mercado. Sendo assim, esse mecanismo pode ser considerado como sendo uma proteção tanto aos geradores quanto aos distribuidores de energia, além de ser um mecanismo de mitigação de riscos de mercado para ambos.

Basicamente, existem dois tipos de MCSD, a seguir:

MCSD "ex-ante": As declarações de sobras e déficits são voluntárias. O MCSD é executado somente para os Distribuidores que apresentem declarações de sobras ou déficits, para todos os meses que houver declarações de sobras. As compensações e devoluções têm caráter irrevogável e irretratável até o final do prazo de vigência do contrato, e é formalizada através de termos de cessão. As 
eventuais quantidades de sobras não compensadas são objeto de aditivo contratual de redução e os valores calculados de compensação e redução de potência têm como base as alterações dos valores médios de energia contratados.

Os valores de compensação e redução são realizados em energia e potência para todos os meses a partir do mês de execução do MCSD até o final do ano corrente, respeitando a sazonalização de energia do Agente cedente, e para todos os anos seguintes até $\mathrm{O}$ ano final de vigência do contrato. $O$ direito de pleitear redução, devido a saída de Consumidor Livre, se concretiza quando da saída do mesmo e se extingue a partir do momento em que o Agente informa ao MME a quantidade declarada de compra de energia (1 ${ }^{\circ}$ de agosto de cada ano). O MCSD contemplará as quantidades referentes a saída de consumidores potencialmente livre, por acréscimo aos contratos anteriores à 16 de março de 2004 e a outros desvios de mercado, nesta ordem de prioridade. Para as sobras decorrentes de outras variações de mercado são realizadas duas aplicações ordinárias do MCSD no decorrer do ano, a primeira sempre no mês de julho e a segunda conforme definido pela ANEEL.

As solicitações de sobras e déficits devem ser encaminhadas à apreciação da ANEEL e, concluída a análise, oficiadas à CCEE para o acionamento do MCSD.

MCSD "ex-post": O MCSD Ex-Post é aplicado para todas as distribuidoras que solicitarem, ocorrendo sempre no Mês de Janeiro antes do cálculo das penalidades para os Distribuidores. O MCSD Ex-Post ocorre de forma multilateral, ou seja, não se identifica os pares Cedentes-Cessionários. Além disso, não altera as quantidades contratadas do passado e nem as quantidades sazonalizadas. As parcelas compensadas são tratadas como Lastro para fins de apuração das penalidades. Os montantes envolvidos de energia são valorados ao "mix" de preços de CCEAR's do ano civil anterior do agente. A receita obtida pela venda das sobras no Mercado de Curto Prazo é considerada nos cálculos do MCSD ExPost. 
O grande risco associado a esse mecanismo de mitigação de risco é que cessão ou recebimento de uma determinada quantidade de energia por uma empresa está associada à disponibilidade dessa energia. Ou seja, caso não haja energia disponível para fazer a troca descrita acima, a CCEE não realiza o MCSD naquele mês. Por esse motivo, é extremamente desaconselhável à qualquer empresa adotar o MCSD como uma ferramenta segura de mitigação de risco de mercado, pois o MCSD pode não ser executado todos os meses do ano.

\subsection{ALOCAÇÃO DOS RISCOS DE MERCADO E MECANISMOS DE MITIGAÇÃO DOS RISCOS}

Expostos todos os riscos de mercado, bem como os seus respectivos mecanismos de mitigação, associados a uma empresa de distribuição de energia, é possível que fazer uma análise crítica bem mais apurada quanto à contratação de energia pela distribuidora.

Para tal, é importante a elaboração de ferramentas que facilitem a identificação e análise dos principais riscos envolvidos nesse processo, como por exemplo, a montagem de gráficos e tabelas comparativa mostrando os principais momentos e riscos de contratação de energia. 


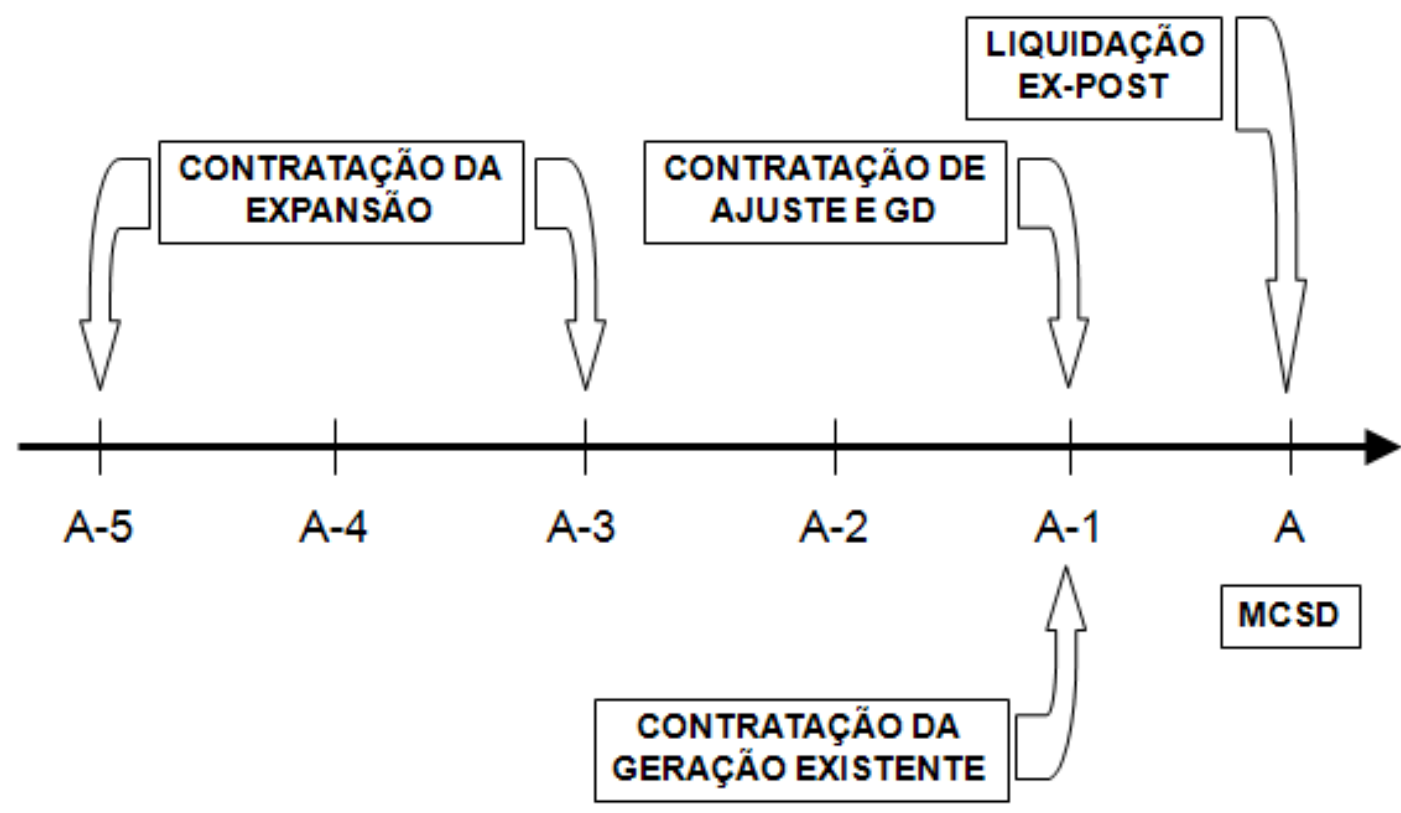

Figura 7 - Momentos de Contratação de Energia

Analisando-se a figura apresentada, pode-se notar que existem vários momentos em que a distribuidora pode contratar energia para atender o seu mercado, sendo que o primeiro deles inicia-se a 5 anos do início do ano de suprimento, e o ultimo deles ocorre já no momento da contabilização do mercado de curto prazo, realizada pela CCEE, que ocorre mensalmente.

A partir dessa figura, é possível ter um panorama geral dos momentos de contratação e dos riscos que podem estar envolvidos nesse processo, fazendo com que as distribuidoras comecem a traçar as suas estratégias, contratando todo o montante de energia necessária logo nos leiloes de A-5 ou deixando para contratar uma parcela da energia mais próximo do ano de suprimento, por exemplo.

No entanto, isso não é o suficiente. São necessárias outras ferramentas de apoio para traçar uma estratégia adequada. E para isso, pode-se utilizar uma tabelaresumo que apresente os principais momentos de contratação associados aos riscos de volume de contração, como por exemplo, a tabela abaixo. 
Tabela 2 - Restrições ao Volume de Contratação de Energia

$$
\begin{array}{cccc} 
& \text { INÍCIO DO } & \text { PRAZO DO } & \text { RESTRICCÕES DE } \\
\text { PRODUTOS } & \text { SUPRIMENTO } & \text { CONTRATO } & \text { VOLUME }
\end{array}
$$

\begin{tabular}{|c|c|c|c|c|}
\hline \multirow{4}{*}{ 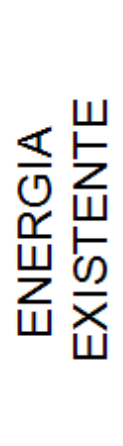 } & $\begin{array}{c}\text { LEILÃO } \\
2004 \text { E } 2005\end{array}$ & 2005 A 2009 & 8 ANOS & NÃO HÁ \\
\hline & "A-1" & EM 1 ANO & $\begin{array}{l}5 \mathrm{~A} 15 \\
\text { ANOS }\end{array}$ & $\begin{array}{c}\text { ATÉ } 1 \% \\
\text { CARGA "A-2" }\end{array}$ \\
\hline & AJUSTE & $\begin{array}{l}\text { ATÉ } 4 \\
\text { MESES }\end{array}$ & $\begin{array}{l}\text { ATÉ } 2 \\
\text { ANOS }\end{array}$ & $\begin{array}{c}\text { ATÉ } 1 \% \\
\text { CONTRATOSANO "A" }\end{array}$ \\
\hline & MCSD & $\begin{array}{l}\text { CESSÃO } \\
\text { IMEDIATA }\end{array}$ & $\begin{array}{l}\text { ATÉ FINAL } \\
\text { CONTRATO }\end{array}$ & $\begin{array}{l}\text { DISPONIBILIDADE } \\
\text { DE SOBRAS }\end{array}$ \\
\hline
\end{tabular}

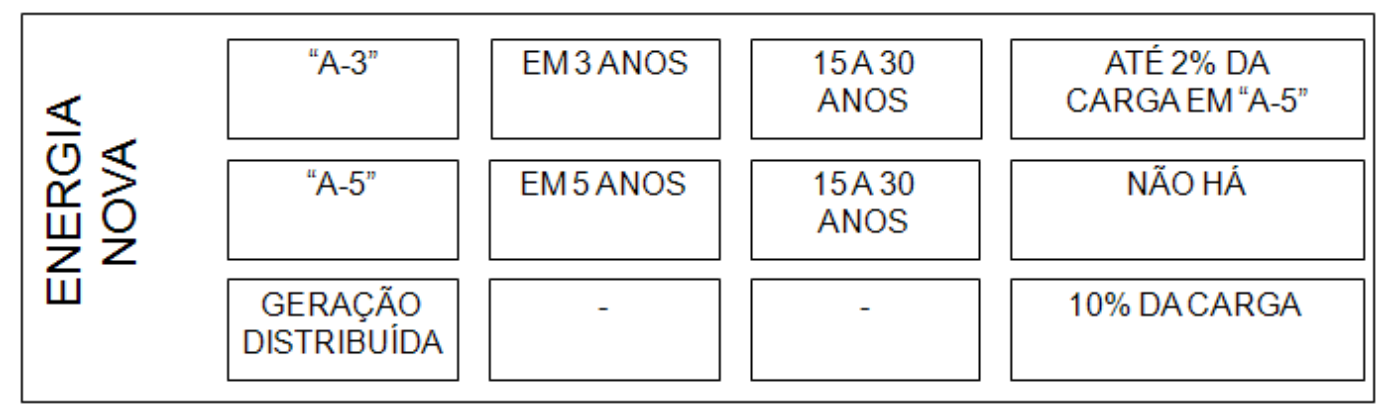

A tabela acima apresenta num mesmo quadro as formas possíveis de contratação de energia pela distribuidora, associando informações dos mesmos e as principais restrições de volume de energia contratada.

É importante ressaltar que a partir de uma tabela-resumo como essa a distribuidora já tem condições de traçar a sua estratégia de atuação quanto a contratação de energia, analisando os montantes a serem contratados em cada mecanismo, utilizando-os como mecanismos de mitigação de riscos de mercado.

No entanto, para finalizar a análise de contratação de energia e utilização dos mecanismos de mitigação de riscos de mercado, a distribuidora precisa elaborar uma outra tabela-resumo semelhante a acima apresentada, porém com riscos de repasse tarifário, pois, conforme a legislação vigente, o custo associado a aquisição de energia não é automaticamente repassado as tarifas dos 
consumidores finais e o montante a ser repassado tem que se submeter ao crivo de critérios de enquadramento.

No capítulo 7 , onde será discutido em maior detalhe o repasse dos custos de aquisição de energia à tarifa dos consumidores finais, será apresentada a tabela com os riscos de repasse tarifário associados à aquisição de energia.

Por sua vez, no capítulo 9, será elaborado um estudo de caso onde serão utilizadas todas as ferramentas apresentadas. 


\section{TARIFAS DE ENERGIA ELÉTRICA}

Segundo o contrato de concessão de cada distribuidora, a receita inicial da concessionária é dividida em duas parcelas: parcela A e parcela B. A parcela " $A$ " envolve os chamados "custos não gerenciáveis" pela concessionária, explicitamente indicados no contrato. São custos cujo montante e variação escapam à vontade ou influência da concessionária, como a energia elétrica adquirida para atendimento aos clientes, os custos de transmissão e os encargos setoriais. A parcela "B" compreende o valor remanescente da receita, envolvendo os ditos "custos gerenciáveis", que estão sujeitos ao controle ou influência das práticas gerenciais adotadas pela concessionária - ou seja, os custos de operação (pessoal, material e serviços de terceiros), manutenção e remuneração do capital.

O contrato de concessão determina que, anualmente, sejam repassadas integralmente as variações anuais de custos observadas na parcela "A". Já a parcela "B" é reajustada anualmente pelo IGP-M, com vistas à sua atualização monetária, sendo que o referido índice de preços é ajustado por um Fator " $X$ ", determinado pela ANEEL na revisão tarifária periódica. Tais regras estimulam a concessionária a reduzir os custos de operação (cobertos pela Parcela B da receita) ao longo do período anterior à revisão tarifária, uma vez que custos menores para um mesmo nível real de tarifas, implicam em maiores benefícios para a concessionária, sob a forma de maior remuneração do capital. Portanto, a remuneração da concessionária não está garantida, mas depende de uma gestão eficiente dos chamados custos gerenciáveis.

Resumindo, anualmente é realizado o reajuste tarifário das empresas de distribuição e, na maior parte dos casos, a cada quatro (4) anos é realizada a revisão tarifária periódica.

O gráfico abaixo ilustra o efeito do regime de preços máximos sobre as tarifas. Para simplificar, supõe-se que as variações do índice que reajusta anualmente a parcela "B" (IGP-M) e dos custos da parcela "A" sejam iguais a zero ao longo do 
primeiro período tarifário. A tarifa (ou "preço máximo"), inicialmente fixada em T1, permanece com seu valor fixo (em termos reais) no primeiro período tarifário, ou seja, até a primeira revisão tarifária periódica. Isso significa que a concessionária tem a oportunidade de reduzir custos de operação e, assim, aumentar sua remuneração ao longo desse período. Se a concessionária for eficiente, poderá se apropriar do aumento da remuneração resultante de sua gestão ao longo desse período.

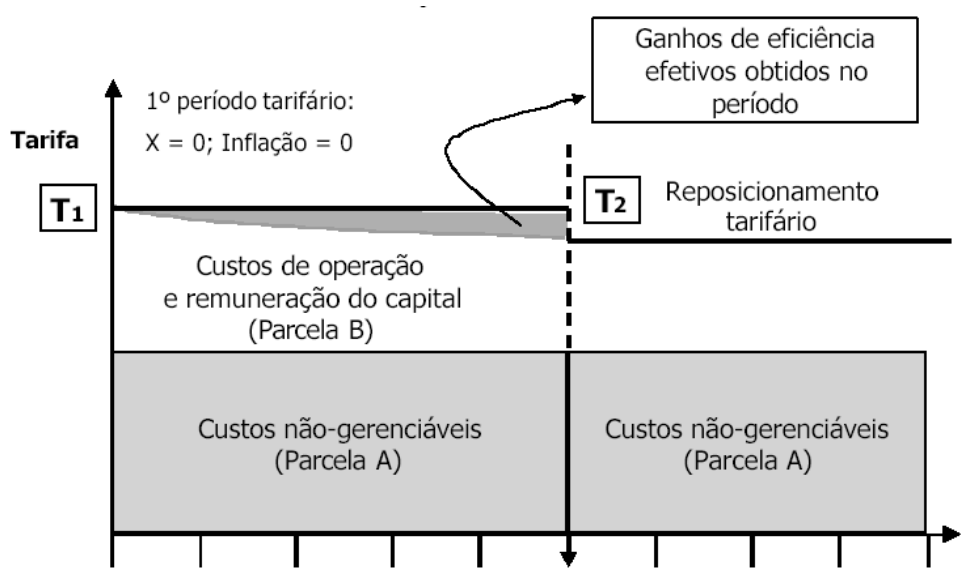

Fonte: ANEEL, 2008

Figura 8 - Revisão Tarifária

Ao final do primeiro período tarifário ocorre a primeira revisão tarifária periódica. $A$ primeira etapa é o reposicionamento tarifário, no qual se busca estabelecer tarifas compatíveis com a cobertura dos custos operacionais eficientes - para um dado nível de qualidade do serviço - e com a obtenção de um retorno justo e adequado sobre investimentos realizados com prudência. Essa equação requer a definição, pelo regulador, das seguintes variáveis: i) custos operacionais eficientes; ii) taxa de retorno; iii) estrutura de capital; e iv) base de remuneração (investimento a ser remunerado). A segunda etapa consiste no Fator $X$, que é o estabelecimento de metas de eficiência para o segundo período tarifário que serão expressas na tarifa. 
Nas seções seguintes serão mais detalhados os processos de revisão e reajuste tarifários das empresas de distribuição de energia.

\subsection{COMPOSIÇÃO DA RECEITA REQUERIDA (PARCELAS “A” E "B”)}

Para fins de reajuste tarifário, a receita da concessionária é dividida em duas parcelas:

i. A parcela A é a parcela da receita correspondente aos seguintes custos: cota da Reserva Global de Reversão - RGR; cotas da Conta de Consumo de Combustíveis - CCC; valores relativos à fiscalização dos serviços concedidos; compra de energia elétrica; e encargos de acesso e uso dos sistemas de transmissão e distribuição de energia elétrica para revenda;

ii. A parcela B representa o valor remanescente da receita da concessionária, excluído o ICMS, após a dedução da Parcela A, e corresponde aos seguintes custos: Remuneração do Capital; cotas de Reintegração Regulatória, e Operação e Manutenção.

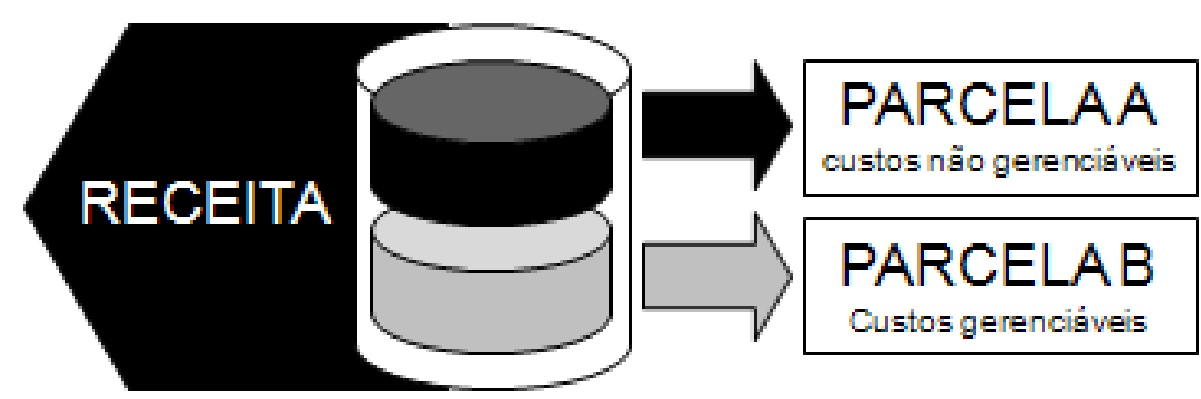

Fonte: ANEEL, 2008

Figura 9 - Receita Requerida 


\subsubsection{Parcela "A" - Custos Não Gerenciáveis}

A Parcela A inclui os denominados custos "não-gerenciáveis" da concessionária, isto é, custos cujos montantes e variação não são administrados pela concessionária. Tais custos referem-se à compra de energia elétrica e aos encargos tarifários.

\subsubsection{Compra de Energia Elétrica}

Para atendimento a seu mercado de referência, a concessionária de distribuição compra energia elétrica através dos leilões de aquisição de energia elétrica, mediante quotas do Programa de Incentivo às Fontes Alternativas de Energia PROINFA, através de contratos bilaterais celebrados antes da Lei no 10.848 , de 15 de março de 2004 e, no caso da energia produzida por Itaipu Binacional, mediante quotas definidas pela legislação. Algumas concessionárias complementam a compra de energia elétrica a partir do Mecanismo de Compensação de Sobras e Déficits - MCSD. Num passado recente, as distribuidoras adquiriam energia elétrica através de contratos iniciais, contratos bilaterais negociados diretamente entre vendedor e comprador, e aquisições no mercado de curto prazo. Esses custos também são repassados aos consumidores finais quando da revisão tarifária.

Para o cálculo dos custos com compra de energia elétrica toma-se como ponto de partida os montantes adquiridos pela concessionária mediante contratos iniciais, Itaipu, contratos bilaterais, e leilões públicos de energia. Para compor a Parcela A da Receita Requerida devem ser considerados apenas os montantes de compra 
de energia elétrica necessários para o atendimento ao mercado de referência previsto para o ano-teste ${ }^{4}$, acrescido de um adicional a título de perdas de energia elétrica. A diferença a maior desse montante deve ser considerada sobra de energia contratada e não compor a Receita Requerida.

Para manter a neutralidade da Parcela $A$, torna-se necessário calcular a valoração dos montantes de energia admitidos para o ano-teste pelas tarifas que estarão vigentes na data de revisão tarifária periódica da concessionária.

\subsubsection{Encargos Setoriais e Custos com Transporte de Energia}

Os encargos tarifários são todos definidos em Leis e seus valores são estabelecidos por Resoluções ou Despachos da ANEEL, para efeito de pagamento pelas concessionárias e de repasse às tarifas de fornecimento de energia elétrica. Alguns desses encargos foram inicialmente definidos em Lei e, posteriormente, convalidados em Decretos, constituindo, dessa forma, políticas de Governo para o setor elétrico. Esses encargos tarifários são:

- Conta de Consumo de Combustíveis - CCC: Refere-se ao rateio dos ônus e vantagens do consumo de combustíveis fósseis para geração de energia termoelétrica. A geração termoelétrica se faz necessária quando as condições de geração de energia hidroelétrica são insuficientes para o atendimento ao mercado. Além disso, a geração termoelétrica também se faz necessária nas regiões do país localizadas fora da área de atendimento pelo sistema interligado, como na região Norte, nos denominados sistemas isolados. Os custos da geração termoelétrica são rateados por todos os consumidores do país, mediante a fixação de valores anuais para cada concessionária de distribuição, em função do seu mercado e podem variar

\footnotetext{
${ }^{4}$ Refere-se ao período de 12 meses subseqüentes à data da revisão tarifária
} 
em função da necessidade maior ou menor do uso das usinas termoelétricas. A partir de 2008 os estados do Sul e Sudeste deixaram de contribuir com a CCC para o sistema interligado. Os valores da CCC são fixados anualmente pela ANEEL com base nas informações prestadas pela ELETROBRÁS com relação às condições previstas de hidraulicidade, a taxa esperada de crescimento do consumo para o ano corrente e aos preços esperados dos combustíveis.

- Reserva Global de Reversão - RGR: Trata-se de parcela cujo valor anual é estabelecido pela ANEEL com a finalidade de prover recursos para reversão, encampação, expansão e melhoria do serviço público de energia elétrica, para financiamento de fontes alternativas de energia elétrica, para estudos de inventário e viabilidade de aproveitamentos de potenciais hidráulicos, bem como para desenvolvimento e implantação de programas e projetos destinados ao combate ao desperdício e uso eficiente da energia elétrica, bem como subsidiar a classe de consumo classificada com residencial baixa renda. Seu valor anual equivale a 2,5\% dos investimentos efetuados pela concessionária em ativos vinculados à prestação do serviço de eletricidade e limitado a 3,0\% de sua receita anual. A Quota de RGR fixada anualmente é paga mensalmente em duodécimos pelas concessionárias às Centrais Elétricas Brasileiras - ELETROBRÁS, que é a gestora dos recursos arrecadados para esse fim.

- Taxa de Fiscalização de Serviços de Energia Elétrica (TFSEE): equivale a 0,5\% do benefício econômico anual auferido pela concessionária. Trata-se de parcela cujo valor anual é estabelecido pela ANEEL com a finalidade de constituir sua receita e destina-se à cobertura do custeio de suas atividades. A TFSEE fixada anualmente é paga mensalmente em duodécimos pelas concessionárias.

- Operador Nacional do Sistema - ONS: Para o atendimento ao mercado consumidor de sua área de concessão a concessionária de distribuição recebe a energia elétrica adquirida das empresas geradoras através de 
instalações de transmissão (subestações e linhas de transmissão). As atividades de coordenação e de controle da operação da geração e transmissão de energia elétrica são executadas pelo Operador Nacional do Sistema - ONS. Assim, além dos encargos relativos ao uso das instalações da rede básica, as concessionárias distribuidoras pagam mensalmente valores relativos ao custeio das atividades do ONS.

- Uso das Instalações da Rede Básica - RB: O Uso das Instalações da Rede Básica de Transmissão de Energia Elétrica refere-se aos valores pagos pelas concessionárias de distribuição às Transmissoras conforme Contrato de Uso do Sistema de Transmissão - CUST celebrado com o ONS pelo acesso à rede básica de transmissão do sistema interligado.

- Uso das Instalações de Conexões - IC: O Uso das Instalações de Conexão refere-se ao uso, pelas concessionárias distribuidoras, das instalações de conexão não integrantes da rede básica e pertencentes às Transmissoras, para conectar-se às instalações da rede básica de transmissão. Os encargos de uso dos sistemas de conexão referem-se aos valores pagos pelas concessionárias distribuidoras às Transmissoras, em função do uso das instalações destas, e são objeto de contrato entre as partes.

- Transporte de Energia Elétrica Proveniente de Itaipu Binacional - TI: O Transporte da Energia Elétrica Proveniente de Itaipu Binacional refere-se ao custo de transporte da quota parte de energia elétrica adquirida pela concessionária, daquela geradora. A despesa com transporte de energia elétrica proveniente de Itaipu é o resultado da multiplicação do montante de demanda de potência (MW) adquirida pela tarifa de transporte de Itaipu fixada pela ANEEL em $\mathrm{R} \$ / \mathrm{MW}$. As distribuidoras detentoras das quotas partes de Itaipu pagam também pelos Encargos de Uso da Rede Básica atribuídos à Itaipu Binacional, de forma proporcional às suas quotas.

- Conta de Desenvolvimento Energético - CDE: Trata-se de parcela cujo valor anual é estabelecido pela ANEEL com a finalidade de prover recursos 
para: i) o desenvolvimento energético dos Estados; ii) a competitividade da energia produzida a partir de fontes eólica, pequenas centrais hidrelétricas, biomassa, gás natural e carvão mineral, nas áreas atendidas pelos sistemas elétricos interligados; iii) promover a universalização do serviço de energia elétrica em todo o território nacional; iv) subsidiar a tarifa do sub grupo denominado "Baixa Renda". A CDE, cuja duração é de 25 anos, é fixada anualmente e paga mensalmente pelas concessionárias à ELETROBRÁS, que é a entidade que movimenta os recursos arrecadados para esse fim.

- Programa de Incentivo às Fontes Alternativas de Energia Elétrica PROINFA: instituído com o objetivo de aumentar a participação de fontes alternativas renováveis na produção de energia elétrica (energia eólica, biomassa e pequena central hidrelétrica), privilegiando empreendedores que não tenham vínculos societários com concessionárias de geração, transmissão ou distribuição de energia elétrica, visando, também, ao aumento da participação de agentes no setor elétrico. A responsabilidade pela contratação da energia elétrica gerada no âmbito do PROINFA é da ELETROBRÁS, de forma que todos os custos concernentes à aquisição da energia gerada pelo PROINFA incorridos pela ELETROBRÁS, são rateados por todas as classes de consumidores finais atendidos pelo Sistema Elétrico Interligado - SIN, exceto os integrantes da classe residencial baixa renda.

- Encargos de Serviço do Sistema - ESS: representa o custo incorrido para manter a confiabilidade e a estabilidade do Sistema para o atendimento da carga, apurado mensalmente pela CCEE e pago pelos agentes da categoria de consumo aos agentes de geração que prestarem serviços não remunerados pelo Preço de Liquidação de Diferenças - PLD. A maior parte desse encargo diz respeito ao pagamento para geradores que receberam ordem de despacho do ONS para atendimento a restrições de transmissão. 
- Pesquisa e Desenvolvimento - P\&D e Eficiência Energética: estabelece que as concessionárias e permissionárias de serviços públicos de distribuição de energia elétrica ficam obrigadas a aplicar anualmente o montante de, no mínimo, $0,50 \%$ de sua receita operacional líquida em pesquisa e desenvolvimento do setor elétrico e, no mínimo, 0,50\% em programas de eficiência energética. Para efeito de obtenção dos valores a investir em P\&D e recolher ao Fundo Nacional de Desenvolvimento Científico e Tecnológico - FNDCT e ao Ministério de Minas e Energia MME, deve ser utilizada a metodologia de cálculo da Receita Operacional Líquida - $\mathrm{ROL}^{5}$, a ser observada por todas as empresas de energia elétrica que devem atender à Lei no 9.991/2000.

\subsubsection{Parcela "B" - Custos Gerenciáveis}

Valor remanescente da receita da concessionária, excluído o ICMS, após a dedução da Parcela A, isto é, os Custos Gerenciáveis. Os custos gerenciáveis são compostos por:

- Remuneração do Capital;

- Quotas de Reintegração Regulatória:

- Operação e Manutenção.

A remuneração sobre o capital investido, que deve ser incluída nas tarifas, é o resultado da aplicação da taxa de retorno adequada para a atividade de distribuição no Brasil sobre o investimento a ser remunerado, ou base de remuneração.

\footnotetext{
${ }^{5}$ A metodologia de cálculo da Receita Operacional Líquida - ROL pode ser obtida no Manual do Programa de Pesquisa e Desenvolvimento Tecnológico do Setor de Energia Elétrica, disponível no endereço http://www.aneel.gov.br/cedoc/aren2008316_2.pdf
} 
Para o cálculo da taxa de retorno, a ANEEL adota a metodologia internacionalmente consagrada do Custo Médio Ponderado de Capital (Weighted Average Cost of Capital - WACC), incluindo o efeito dos impostos sobre a renda. Esse enfoque busca proporcionar aos investidores um retorno igual ao que seria obtido sobre outros investimentos com características de risco comparáveis. Esta metodologia de cálculo (WACC) está fora do contexto desse trabalho. Para tal, recomenda-se a leitura das notas técnicas da ANEEL que tratam do processo de revisão tarifária das empresas distribuidoras, como por exemplo a Nota Técnica ํo 184/2007-SRE/ANEEL, que trata da segunda revisão tarifária periódica da empresa ELETROPAULO.

A quota de reintegração regulatória é composta das quotas de depreciação e de amortização e representa a forma de recomposição dos investimentos realizados para prestação do serviço ao longo da vida útil desses bens.

Para a elaboração e definição dos custos de Operação e Manutenção da empresa, é utilizada uma ferramenta da Empresa de Referência (ER), que auxilia na análise de consistência dos resultados obtidos, determinando assim custos operacionais eficientes aderentes às reais condições econômicas e geofísicas as quais a empresa está inserida.

Para tanto, devem ser contemplados e dimensionados os seguintes itens:

- Recursos Humanos (administrativo e de Operação e Manutenção);

- Infra-estrutura física (móveis, edificações e sistemas de informática);

- Materiais e serviços;

- Transporte.

A partir disso, determinam-se os Processos e Atividades (P\&A) da empresa, analisando-se uma estrutura organizacional referencial, contemplando a definição dos postos de trabalho que a integram, a dotação dos recursos humanos de cada 
um deles e a remuneração dos mesmos. A organização da distribuidora requer o cumprimento de funções básicas, e que serão utilizadas na composição da Empresa de Referência (ER), como: i) Direção, Estratégia e Controle; ii) Adminsitração; iii) Finanças; iv) Comercial; v) Técnica.

Para efeito de determinação dos custos da estrutura de Administração, dos custos diretos e indiretos de Operação e Manutenção das instalações e das atividades de Comercialização, torna-se necessário desenhar uma Empresa de Referência (ER) que tenha uma estrutura eficiente e que realize suas atividades de maneira que os custos resultantes correspondam aos que existiriam no âmbito de um mercado competitivo. Desse modo se obtém, a partir da consideração dos P\&A típicos e de uma estrutura de administração adaptada à realidade geo-econômica da distribuidora, o dimensionamento apropriado da Empresa de Referência, dotado dos recursos necessários para uma empresa caracterizada como eficiente.

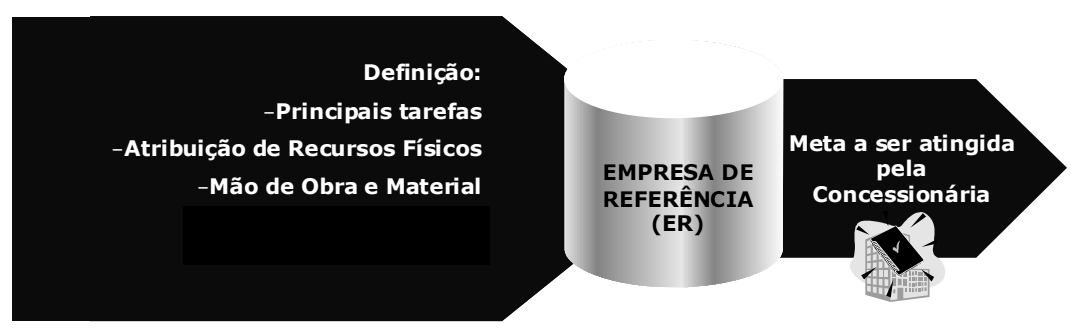

Fonte: ANEEL, 2008

Figura 10 - Empresa de Referência

É importante registrar que os custos operacionais eficientes da "Empresa de Referência" incluem as despesas requeridas para a incorporação e operação dos sistemas informatizados de gestão (SIG) que tornam possível o cumprimento de todas as funções de suporte do ciclo comercial, assim como a gestão das anomalias no fornecimento elétrico que recebem os clientes (interrupções no serviço e outras perturbações) com altíssima confiabilidade. 


\subsection{O REAJUSTE ANUAL}

Os reajustes anuais, que dão origem aos conhecidos Índices de Reajuste Tarifário (IRT), são calculados anualmente para todas as empresas distribuidoras, exceto nos anos em que ocorrem as revisões tarifárias periódicas.

O reajuste tarifário anual pretende oferecer à concessionária a perspectiva de que, no período entre revisões tarifárias, o equilíbrio econômico-financeiro de sua concessão não sofrerá a corrosão do processo inflacionário, sendo-lhe permitida a apropriação de parte dos ganhos de eficiência econômica que vier a alcançar no período.

Para o cálculo do IRT Total, duas (2) parcelas devem ser consideradas: o IRT econômico e o IRT financeiro.

$$
I R T \text { total }=I R T \text { econômico }+I R T \text { financeiro }
$$

\section{Equação 1 - IRT Total}

O IRT econômico representa o repasse dos custos que permanecem na tarifa no próximo reajuste / revisão. Já o IRT financeiro representa o repasse dos custos temporários na tarifa (não compõem base para o próximo reajuste / revisão).

Nesse cálculo, são levadas em consideração as duas (2) parcelas: A parcela composta pela evolução dos custos que independem de decisões das concessionárias (Parcela A), e a parcela composta pelos custos que dependem essencialmente da eficácia da gestão empresarial (Parcela B). O índice geral de preços de mercado (IGPM) da Fundação Getúlio Vargas é utilizado como indexador de custos para os custos controláveis, e " $X$ " é o fator de indução à melhoria da eficiência econômica das atividades monopolistas. Além disso, é 
levado em consideração a receita anual da concessionária correspondente ao ano em que a tarifa será aplicada e ao ano imediatamente anterior.

$$
I R T=\frac{V_{P A 1}+V_{P B 0} \times(I G P M-X)}{R_{\text {adquirida } 0}}
$$

\section{Equação 2 - Composição do IRT}

onde:

IRT = reajuste tarifário que deve ser aplicado anualmente;

$\mathrm{V}_{\mathrm{PA1}}=$ custos que independem de decisões das concessionárias (CCC, RGR, TFSEE, etc.);

$\mathrm{V}_{\mathrm{PBO}}=$ custos que dependem essencialmente da eficácia da gestão empresarial (pessoal, materiais, serviços de terceiros, etc.);

IGPM = índice geral de preços de mercado da Fundação Getúlio Vargas. É utilizado como indexador de custos para os custos controláveis;

$X=$ fator de indução à melhoria da eficiência econômica das atividades monopolistas;

$\mathrm{R}_{\mathrm{adquirida} 0}=$ receita anual da concessionária;

Índices 1 e $0=$ correspondem ao ano em que a tarifa será aplicada e ao ano imediatamente anterior, respectivamente.

É importante notar que, tanto nas parcelas de custos quanto na parcela de receita da fórmula acima, não devem ser contabilizados os valores relativos à aquisição $\mathrm{e}$ à comercialização de energia para os consumidores livres, contudo, deve ser contabilizada na parcela de custos não controláveis a compra de energia para os consumidores regulados. Tampouco devem ser contabilizados os custos relativos 
às atividades não vinculadas à prestação de serviços elétricos como, por exemplo, a venda de serviços para telefonia.

\subsection{A REVISÃO PERIÓDICA}

Trata-se de um processo de revisão dos valores das tarifas das empresas que detém concessão pública para prestar serviço de distribuição de energia elétrica. $\mathrm{Na}$ revisão, a agência reguladora realiza a redefinição das tarifas de energia cobradas dos consumidores. O valor dessas tarifas pode ser alterado para mais ou para menos, dependendo das mudanças ocorridas na estrutura de custos e de mercado das empresas, dos níveis de tarifas observados em empresas similares no Brasil e no exterior, e do estímulo à eficiência e ao equilíbrio tarifário.

O objetivo principal da revisão tarifária é garantir uma tarifa justa para consumidores e investidores e estimular o aumento da eficiência e da qualidade da distribuição de energia elétrica. Isso significa que esse processo prevê mecanismos que incentivam as empresas a reduzirem custos e serem mais eficientes na prestação do serviço de distribuição, bem como contempla formas de fazer com que o aumento de eficiência dessas concessionárias seja compartilhado com os consumidores por meio de reduções das tarifas. Os consumidores ganham porque terão quase sempre uma tarifa menor, além do acesso a um serviço de melhor qualidade. Ganham também as empresas porque poderão se apropriar de parte desse aumento de produtividade.

A revisão tarifária periódica é realizada em duas etapas. A primeira é o reposicionamento tarifário. Durante essa fase, a Aneel estabelece para cada uma das distribuidoras tarifas que sejam compatíveis com a cobertura dos custos operacionais e com a obtenção de um retorno adequado sobre investimentos realizados por essas concessionárias. A segunda etapa consiste na definição do Fator X. O Fator X é o mecanismo que permite repassar aos consumidores, por 
meio das tarifas, projeções de ganhos de produtividade das distribuidoras de energia elétrica.

\subsubsection{Reposicionamento Tarifário}

No reposicionamento tarifário se trata de calcular a Receita Requerida da concessionária, que consiste na receita compatível com a cobertura de custos operacionais eficientes e com um retorno adequado sobre 0 capital prudentemente investido. Como a Receita Requerida é calculada em bases anuais, se trata de estabelecer um fluxo de receita compatível com os custos econômicos da prestação do serviço referenciados ao período de 12 meses subseqüentes à data da revisão tarifária.

O reposicionamento tarifário é o resultado da comparação entre a Receita Requerida (em $R \$$ ) para o ano-teste e a Receita Verificada (em $R \$$ ) da concessionária no mesmo período. A Receita Verificada corresponde à receita que seria auferida pela empresa com as tarifas vigentes antes da revisão tarifária periódica aplicadas ao mercado de venda do ano-teste. Para efeito de modicidade tarifária, são deduzidas da Receita Requerida as receitas obtidas pela concessionária mediante a exploração de atividades extraconcessão, a receita de suprimento de energia elétrica a outras concessionárias e outras receitas.

Sob a ótica da regulação econômica, o processo de definição da tarifa possui duas dimensões: nível e estrutura tarifária. O nível tarifário está relacionado com a receita total auferida pela concessionária de distribuição na venda de energia elétrica. Em última instância, as principais questões regulatórias se expressam na definição do nível tarifário, isto é, na definição da Receita Requerida no momento do reposicionamento tarifário, uma vez que é essa receita que deve contemplar os objetivos de sustentabilidade financeira da concessionária distribuidora e eficiência na prestação do serviço, para os padrões exigidos de qualidade. 
Uma vez estabelecida a Receita Requerida, procede-se à sua alocação entre as distintas categorias de consumidores (industrial, residencial, rural, comercial, etc), mediante a cobrança de tarifas diferenciadas para cada categoria, o que resulta na denominada estrutura tarifária. A estrutura tarifária pode diferenciar-se segundo diversos objetivos: entre clientes, regiões, entre custos fixos e variáveis, ou segundo o nível e o perfil horário e o período de consumo. Na estrutura tarifária vigente no Brasil estão refletidas não apenas as diferenças de custos de prestação do serviço entre consumidores, mas também subsídios implícitos entre classes de consumidores (por exemplo, entre consumidores de baixa e alta tensão) e subsídios explícitos associados a aspectos sociais e distributivos (por exemplo, tarifa para a subclasse residencial baixa renda).

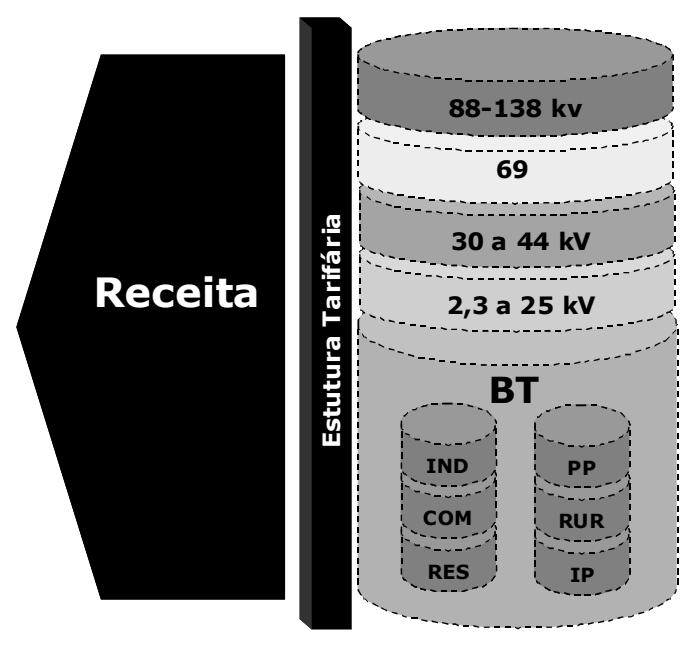

Fonte: ANEEL, 2008

Figura 11 - Estrutura Tarifária

Os consumidores do Grupo "A" deverão ter os contratos de fornecimento de energia elétrica por contratos de uso, conexão e compra de energia. Conseqüentemente, a tarifas de fornecimento deverão ser segregadas em "tarifas fio" e tarifas de energia.

Os consumidores do Grupo "B", por não terem que celebrar contratos de uso, conexão e compra de energia deverão ter suas tarifas de fornecimento 
segregadas na fatura de energia elétrica,de forma a explicitar os componentes relativos ao uso e à compra de energia.

A abertura entre "tarifa fio" e tarifa de energia tem como pressuposto que as tarifas relativas ao uso dos sistemas de distribuição e transmissão refletem adequadamente os custos de atendimento dos grupos e modalidades tarifárias. Disso se conclui que a "tarifa fio" resulta das atuais tarifas de uso dos sistemas de distribuição e transmissão, de forma que a tarifa de energia seja a diferença entre a tarifa de fornecimento vigente e a "tarifa fio". Portanto, a distorção que a ANEEL pretende ter corrigido reside na parcela de energia.

Nesse sentido, para efeito de realinhamento, as tarifas de energia foram determinadas pela composição de duas parcelas. A Parcela I, com peso de $90 \%$, 75\%, 50\%, 25\% e 0\% em 2003, 2004, 2005, 2006 e 2007, respectivamente: tarifa de energia calculada com base na tarifa de fornecimento da estrutura tarifária atual, descontados os correspondentes custos de conexão e de uso do sistema de transmissão ou de distribuição; e a Parcela II, com peso de 10\%, 25\%, 50\%, 75\% e 100\% em 2003, 2004, 2005, 2006 e 2007, respectivamente: tarifa de energia calculada com base no custo da energia disponível para venda, acrescido do custo de comercialização, e, onde couber, de encargos setoriais e tributos.

\subsubsection{Fator "X"}

Uma vez que as tarifas tenham sido reposicionadas segundo a abordagem descrita na seção anterior, são então estimados os ganhos de produtividade para o período tarifário subseqüente que não estão associados a uma gestão mais eficiente da concessionária - que correspondem à área verde na Figura abaixo. No caso do serviço de distribuição de energia elétrica, no qual a evolução tecnológica é gradual, esses ganhos de produtividade projetados têm como causa principal alterações na escala do negócio. 
Durante o período tarifário se produzirão incrementos nas vendas da concessionária, tanto pelo maior consumo dos clientes existentes (crescimento vertical) como pela incorporação de novos clientes na área servida (crescimento horizontal). Esse incremento nas vendas será atendido pela concessionária com custos incrementais decrescentes com relação aos definidos no reposicionamento tarifário. Esse ganho de produtividade do negócio, que não decorre de uma maior eficiência na gestão da concessionária distribuidora, deve ser repassado aos consumidores mediante a aplicação de um redutor do índice que reajusta a Parcela B da receita (IGP-M) e esse redutor consiste no Fator X. As novas tarifas máximas para o próximo período tarifário corresponderão à curva pontilhada da figura a seguir.

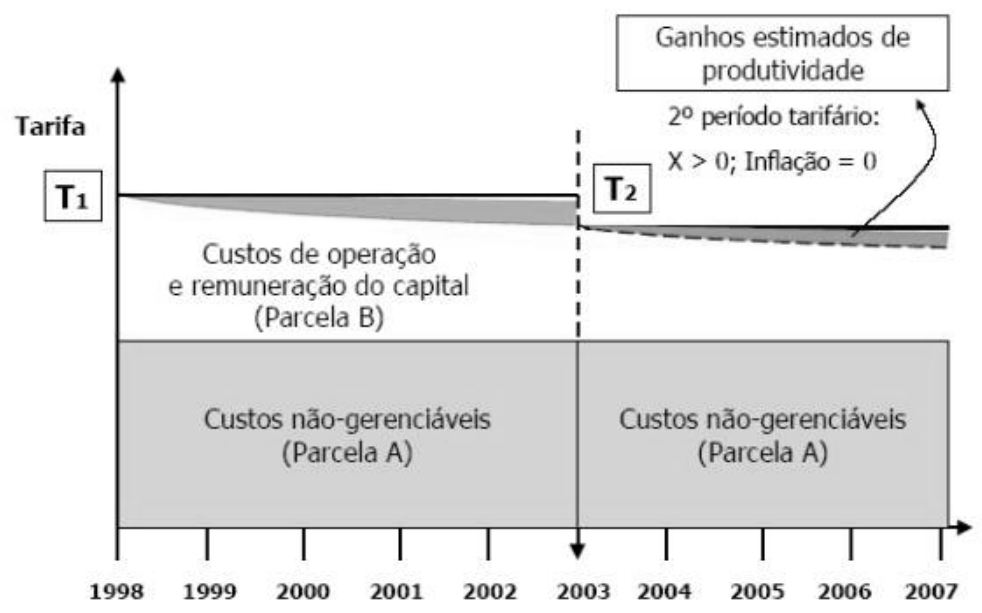

Fonte: ANEEL, 2008

Figura 12 - Reajuste Tarifário

Durante a revisão tarifária é feita uma estimativa dos ganhos de eficiência das concessionárias para os anos seguintes ao processo. São essas estimativas, materializadas no Fator $X$, que são repassadas aos consumidores por meio de redução das tarifas. Isso significa que o "X" definido na revisão será aplicado às tarifas, independentemente da confirmação das projeções de ganhos. Por outro lado, se os ganhos de eficiência das distribuidoras forem maiores que os projetados na revisão, as empresas poderão se apropriar dessa diferença entre o 
resultado estimado e o efetivamente realizado. Em resumo, ao melhorar sua produtividade, as distribuidoras podem aumentar seu lucro.

Assim como no primeiro período tarifário, a concessionária distribuidora tem um forte incentivo para obter uma maior eficiência em sua gestão, já que poderá reter como benefícios a diferença entre os custos operacionais eficientes definidos na revisão tarifária periódica e os que efetivamente possa alcançar. Da mesma forma, se essa diferença é negativa, a concessionária sofrerá uma redução em suas expectativas de benefícios. Na realidade, aquelas concessionárias que durante 0 primeiro período tarifário conseguiram funcionar com custos operacionais inferiores aos reconhecidos nas tarifas vigentes no período, retiveram como benefícios essas diferenças de custos. Essa situação se repete nos períodos tarifários seguintes, já que constitui um dos elementos fundamentais do enfoque regulatório baseado em incentivos, como o que se aplica atualmente no serviço de distribuição de energia elétrica no Brasil.

A aplicação efetiva do Fator $X$ no segundo período tarifário (segundo o que estabelece os contratos de concessão o Fator $X$ foi igual a zero durante no primeiro período tarifário) determina que os ganhos de eficiência só poderão ser apropriados pela concessionária na medida em que ultrapassarem o Fator $\mathrm{X}$, ao longo do segundo período (2004 - 2006). Portanto, quanto maior for a eficiência da concessionária, tanto maior será seu benefício. Se, porém, a concessionária não explorar seu potencial de eficiência, o resultado será a sujeição a uma perda ou, pelo menos, a uma redução de benefícios. A área em amarelo do Gráfico 3 corresponde aos benefícios que podem ser auferidos pela concessionária ao realizar uma trajetória de custos ainda mais eficientes que os considerados no reposicionamento tarifário. 


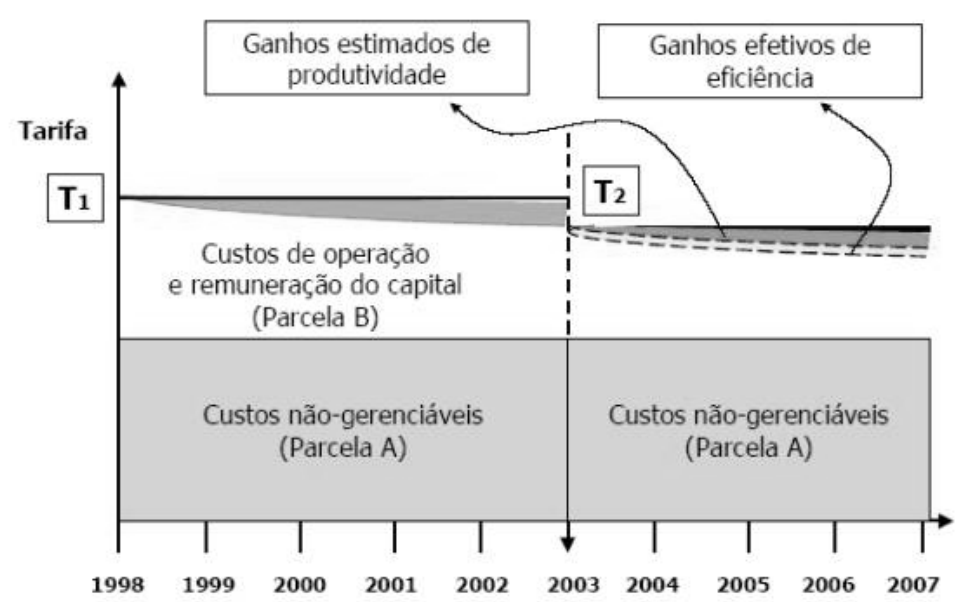

Fonte: ANEEL, 2008

Figura 13 - Fator "X"

Poderia se argumentar contra a ampliação da remuneração obtida pela concessionária eficiente e que os ganhos de eficiência deveriam refletir-se imediatamente na redução das tarifas, de modo a beneficiar unicamente os consumidores. Esse raciocínio é contraditório com os princípios fundamentais da regulação por incentivos e, portanto, se revela indefensável. É que a determinação de que todo ganho de eficiência seja imediatamente repassado aos consumidores significaria um desincentivo para a obtenção de eficiência pela concessionária, isto é, se nenhum benefício lhe trouxesse a redução dos custos, a concessionária não realizaria esforço algum nesse sentido. 


\section{O REPASSE DOS CUSTOS DE AQUISIÇÃO DE ENERGIA ELÉTRICA ÀS TARIFAS DO CONSUMIDOR FINAL}

Pela legislação do setor elétrico vigente, é assegurado ao agente distribuidor o repasse dos custos de aquisição de energia elétrica às tarifas do consumidor final. No entanto, esse repasse não pode ser feito de maneira simplista, alocando para o consumidor final todo o custo referente a uma eventual má gestão do distribuidor no momento da aquisição da energia elétrica.

Isso seria um estimulo a ineficiência, uma vez que o agente distribuidor poderia repassar todo custo de aquisição de energia, não importando se a aquisição foi feita de maneira eficaz ou não.

Se por um lado o agente distribuidor deve ser ressarcido justamente pelo serviço prestado aos seus consumidores, por outro o consumidor final não pode arcar com todo ônus atribuído a má gestão da empresa.

Com o objetivo de equalizar essa relação, foram criadas algumas condições de mercado para que o repasse dos custos de aquisição de energia elétrica seja feito de forma justa, sem prejuízo das partes envolvidas.

O objetivo principal dessas condições de mercado é "induzir" o agente distribuidor a realizar a aquisição de energia elétrica da forma mais eficaz possível, não onerando o consumidor final injustamente.

\subsection{REPASSE DOS CUSTOS DE AQUISIÇÃO DE ENERGIA ELÉTRICA ADQUIRIDA EM LEILÕES}

O repasse dos custos de aquisição de energia elétrica adquirida em leilões é a principal parcela de repasse das distribuidoras. Todos os leilões regulados de 
aquisição de energia têm direito a repasse dos custos de aquisição de energia elétrica às tarifas dos consumidores finais. No entanto, existem algumas restrições de repasse tarifário, induzindo assim as distribuidoras a otimizarem a contratação de energia, contribuindo, dessa forma, para a modicidade tarifária do setor.

Ao se analisar a legislação de maneira simplista, pode-se chegar a conclusão que os custos de aquisição de energia elétrica oriundos de leilões de energia deveriam ser integralmente repassados ao consumidor final. Isso porque os leilões são realizados na modalidade "menor tarifa", o que em tese já estaria contribuindo para a modicidade tarifária.

No entanto, analisando a legislação de uma maneira mais "profunda", nota-se que apesar dos leilões contribuírem para a modicidade tarifária, a quantidade de energia contratada é uma decisão única e exclusiva da distribuidora. Dessa forma, o agente distribuidor poderia deixar de contratar energia em leilões de energia nova (A-5 e A-3) e contratar energia de empreendimentos existentes, pois a tendência é que a tarifa do empreendimento existente seja menor que a tarifa do empreendimento novo, tendo em vista que, nos leilões de energia existente, a entrega da energia é quase que imediata e o prazo de vigência do contrato é mais curto, com maior influência da conjuntura do mercado. Como normalmente o preço da energia no mercado de curto prazo (influência conjuntural) é baixo, o preço da energia nesses tipos de leilões também tende a ser baixo na maior parte do tempo.

O resultado disso seria a falta de oferta de energia, pois a não contratação da energia em leilões de energia nova contribui para a não expansão do parque gerador do país. Como conseqüência, foram criados alguns mecanismos indutores à contratação eficiente nos leilões de A-5 e A-3.

O primeiro deles é o repasse de um valor único para compensar os custos de aquisição de energia proveniente de empreendimentos novos. Esse valor seria dado pela média ponderada dos custos de aquisição de energia nos leilões de 
"energia nova" A-5 e A-3, calculado para o conjunto das distribuidoras. A esse valor dá-se a denominação de VR - Valor Anual de Referência, e representa a "média do mercado".

Dessa forma, a distribuidora que obtiver um custo individual de contratação nos leilões inferior ao VR terá um ganho na contratação, pois poderá repassar à tarifa um valor superior à média do mercado.

$\mathrm{Na}$ prática, esse mecanismo estimula a contratação nos leilões de A-5 e, consequentemente, a expansão do sistema, tendo em vista que o custo de aquisição de energia nos leilões de A-5 tende a ser menor do que nos leilões de A-3. O VR é aplicado nos 3 primeiros anos de vigência dos contratos de energia provenientes de novos empreendimentos. A partir do $4^{\circ}$ ano os custos individuais de aquisição são repassados integralmente.

O VR também é usado como limite máximo para repasse dos custos de aquisição de energia proveniente de empreendimentos existentes (leilões de A-1), nos leilões de ajuste, e para a contratação de geração distribuída.

Além desse, existem outros mecanismos para indução à contratação eficiente pelas distribuidoras, como poder repassar os montantes contratados até $103 \%$ de sua carga. O objetivo da inclusão deste limite é aumentar a segurança do sistema, pois não é possível fazer uma previsão perfeita da demanda e o limite aceitável para erros nesta projeção, assegurando que os contratos sejam no mínimo iguais à carga, é de $3 \%$.

Outro fator diz respeito a contratação em "A-3". Quando essa exceder $2 \%$ da demanda, o direito de repasse está limitado ao menor dentre os custos de contratação relativos a "A-5" e"A-3",

Considerando os fatores expostos até o momento, uma distribuidora poderia contratar energia proveniente de novos empreendimentos em excesso para, posteriormente, ajustar-se descontratando energia proveniente de empreendimentos existentes. No entanto, isso provocaria uma ineficiência no uso 
de recursos do país. Dessa forma, foi adotada uma restrição a essa pratica de tal forma que caso a aquisição de energia proveniente de empreendimentos existentes seja menor que o limite inferior de contratação, o repasse do custo de aquisição de energia proveniente de novos empreendimentos correspondente a esse valor não contratado será limitado por um redutor.

Durante a transição do Novo para o Novíssimo-Modelo, foi dada uma exceção no que tange ao repasse dos custos de aquisição referentes a empreendimentos existentes. Nesse período, a contratação de energia proveniente de empreendimentos existentes nos leilões "A-1" não deverá exceder a $1 \%$ da demanda, porque todos os leilões deveriam ocorrer em 2004. O que exceder a este limite terá o repasse do custo de aquisição reduzido. Este mecanismo tinha por objetivo incentivar as distribuidoras a contratar o máximo de suas necessidades no leilão de energia proveniente de empreendimentos existentes durante a transição, realizado em 2004, o que de fato aconteceu.

A partir da explanação apresentada e levando em consideração as regras de mercado vigentes, pode-se elaborar uma tabela-resumo contendo informações referentes aos principais momentos de contratação das distribuidoras associadas aos riscos de repasse tarifário aos consumidores finais de energia. 
Tabela 3 - Restrições de Repasse Tarifário na Contratação de Energia
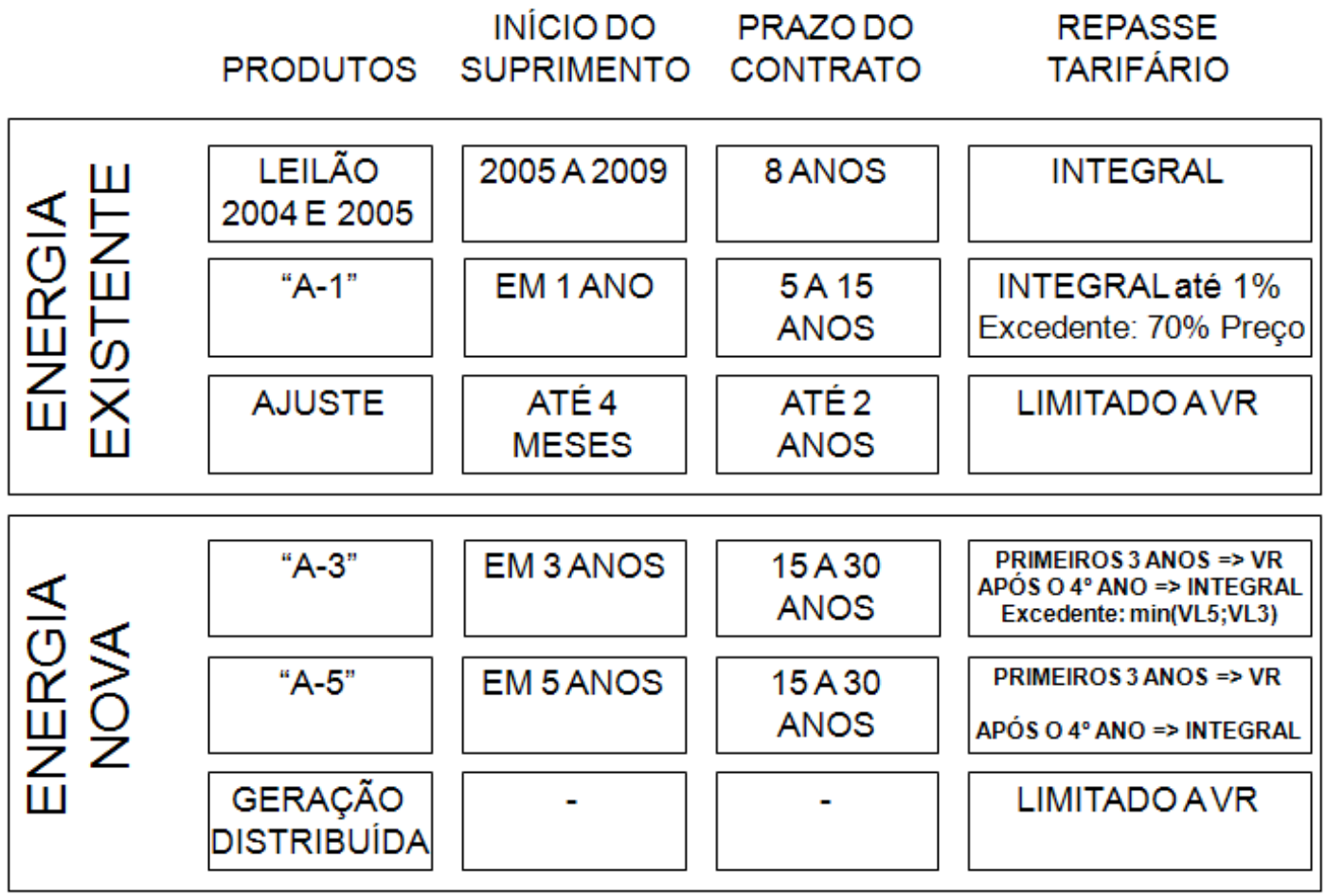

Analisando-se simplesmente essa tabela pode-se notar que dependendo do tipo de "produto" onde foi feita a contratação de energia, existe uma certa restrição quanto ao repasse dos custos de aquisição as tarifas dos consumidores finais de energia. Por isso, para fazer uma contratação eficiente de energia, nos devidos momentos, a distribuidora deve utilizar minimamente as informações contidas nas figuras 1 e 2, já apresentadas no capitulo 5 desse trabalho, bem como da tabela retro apresentada, pois as informações ali contidas se completam e permitem ao agente distribuidor traçar a melhor maneira e o melhor momento de contratação de energia para atendimento ao seu mercado.

No capitulo 9 será elaborado um estudo de caso que exemplifique a aplicação dos conceitos já apresentados. 


\subsection{REPASSE DA SOBRECONTRATAÇÃO}

Conforme descrito no item anterior, existem alguns mecanismos relacionados ao repasse dos custos de aquisição de energia elétrica às tarifas dos consumidores finais, com o objetivo de estimular a eficiência na contratação por parte das distribuidoras e garantir a expansão da oferta de energia, através da construção de novos empreendimentos.

Um dos mecanismos utilizados para a eficientização na aquisição de energia elétrica pelos agentes distribuidores é a limitação do repasse dos custos de aquisição de energia elétrica às tarifas dos consumidores finais em $3 \%$ do Requisito Regulatório.

A limitação do repasse garante uma contratação eficiente pelos consumidores e não onera os consumidores finais.

\subsubsection{Conceitos Básicos}

O Requisito Regulatório é composto por duas parcelas: o Mercado Faturado pela concessionária no ano civil que antecede o reajuste tarifário em processamento, e as Perdas Regulatórias.

Por isso, quando da previsão de carga para a contratação de energia, o agente distribuidor deve levar em consideração o fato de que o montante de energia que ultrapassar os $3 \%$ do requisito regulatório não será repassado às tarifas dos consumidores finais. 
Para fixar melhor o conceito de repasse da sobrecontratação, pode-se visualizar a figura abaixo.

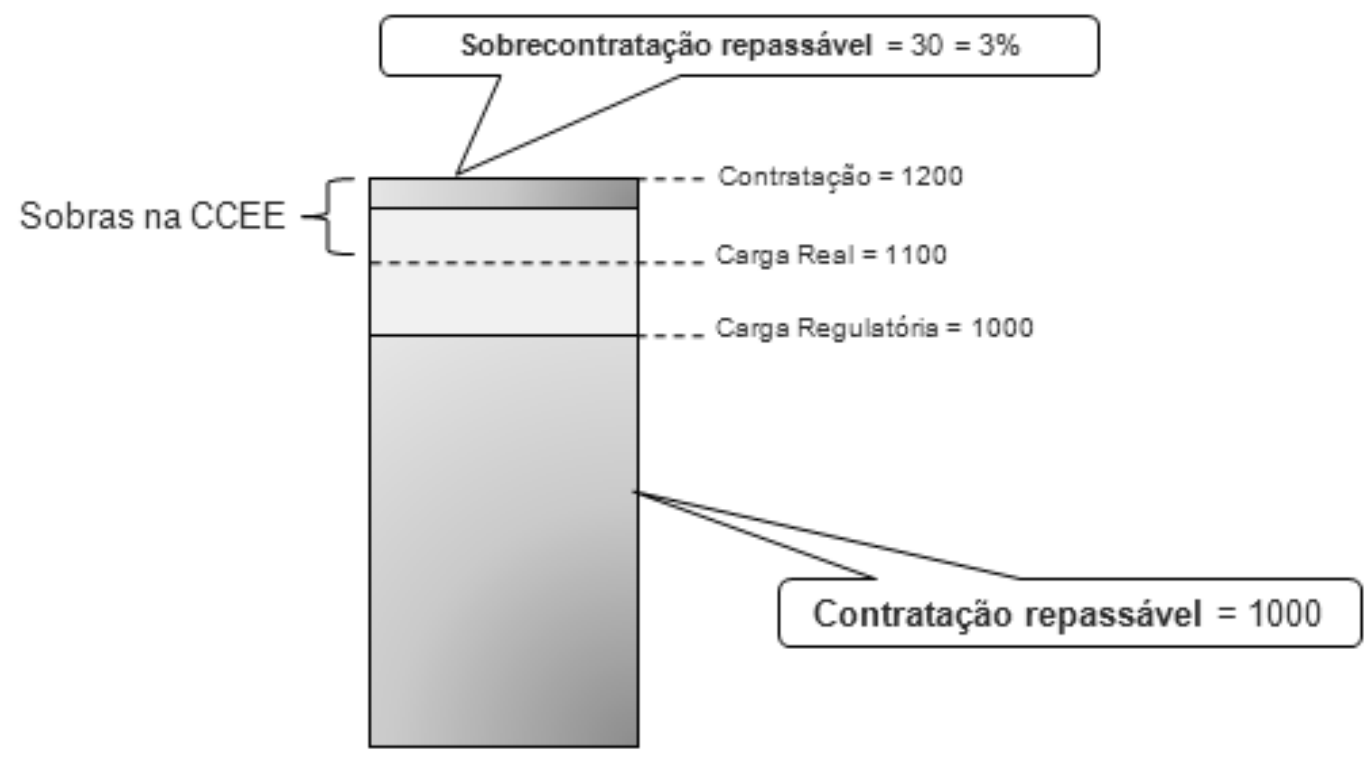

Figura 14 - Conceito de Sobrecontratação

O repasse às tarifas assegurado para a distribuidora é da carga regulatória. O que exceder esse valor, não há garantia de repasse às tarifas. Com isso, o agente é induzido a reduzir as suas perdas, com o objetivo de fazer com que sua carga real seja o mais próximo possível da carga regulatória.

Analisando a figura, pode-se notar claramente que a sobrecontratação repassável às tarifas é bem menor do que a sobrecontratação efetivamente apurada. Daí a importância da eficiência na contratação de energia e da utilização otimizada dos mecanismos de mitigação de riscos de mercado das distribuidoras. 


\subsubsection{Apuração das Sobras e Déficits}

A apuração das sobras e déficits de energia é efetuada mensalmente pela CCEE e posteriormente informada a Aneel. Para fins de repasse às tarifas dos custos de aquisição de energia, podem ser consideradas as sobras e déficits da distribuidora durante $o$ ano civil.

A figura abaixo ilustra as apurações de sobras e déficits ao longo do ano.

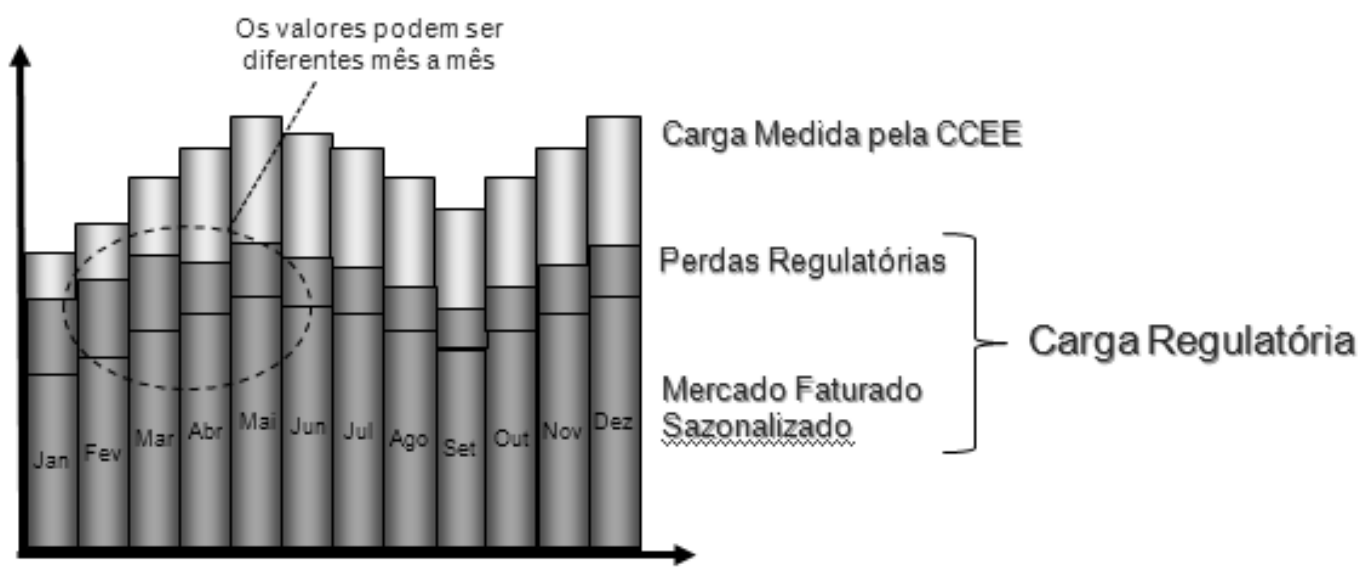

Figura 15 - Apuração de Sobras e Deficits

No entanto, existe um fator muito relevante que diz respeito ao fato de que independente da sobra ou do déficit de energia da distribuidora ao longo do ano, o montante referente à diferença entre a carga regulatória e a carga verificada pela CCEE não pode ser repassada às tarifas.

Dessa forma, as distribuidoras fazem a sazonalização dos seus contratos de aquisição de energia elétrica com o objetivo de alocar da melhor maneira possível a energia ao longo do ano, de tal forma que todos os custos envolvidos na aquisição de energia elétrica sejam repassados às tarifas dos consumidores finais de energia elétrica. 


\subsubsection{A Sazonalização de Energia Elétrica no processo de Repasse dos $103 \%$}

Como descrito no item anterior, as distribuidoras podem, e devem, se utilizar da sazonalização dos contratos de compra de energia elétrica com o objetivo de otimizar o repasse às tarifas dos consumidores finais dos custos de aquisição de energia elétrica.

Mesmo que a distribuidora esteja contratada em exatamente $100 \%$ de seu requisito de energia no ano civil, poderão ocorrer sobras e exposições mensais em função da sazonalização dos contratos (alocação mensal do montante anual de energia contratada), feita com base em sua estimativa de mercado de fornecimento, que poderá ou não se confirmar. Pela regra vigente, as sobras de energia da distribuidora são obrigatoriamente vendidas no mercado de curtoprazo ao PLD, enquanto os déficits de energia também são comprados ao PLD.

Sendo assim, em uma situação de déficit, a energia adquirida pela concessionária no mercado spot é tratada como um contrato de curto prazo. De maneira análoga, toda venda de energia no curto prazo é considerada sobrecontratação e o seu repasse está limitado à $3 \%$ da carga anual regulatória. $\mathrm{O}$ montante de sobras repassáveis são alocados proporcionalmente nos meses em que houve sobra e valoradas ao preço do contrato que sobrou menos o PLD do respectivo mês.

Para efeito de apuração do montante de sobrecontratação, a Resolução Normativa ANEEL ํㅡ 255, de 6 de março de 2007, estabelece em seu artigo 4ㄹ, parágrafos $2^{\circ}$ e $3^{\circ}$ o seguinte:

“...§ 2ㅇ O Montante de Sobrecontratação será formado, prioritariamente, por Contrato de Comercialização de Energia Elétrica no Ambiente de Contratação Regulado - CCEAR, decorrente dos leilóes de energia proveniente de empreendimentos existentes e, se necessário, complementado por montantes referentes aos Leilões de Ajustes, à geração distribuída contratada nos termos do inciso I do art. $2^{\circ}$ da Resolução Normativa $n^{\circ}$ 167, de 
10 de outubro de 2005, ao CCEAR de novos empreendimentos de geração e aos outros contratos bilaterais.

$\S 3^{\circ}$ A compra de energia proveniente de geração distribuída, contratada nos termos do inciso II, do art. 2ㅇ da Resolução Normativa no 167 de 2005, terá a mesma prioridade dos contratos bilaterais, quando da formação do Montante de Sobrecontratação..."

Diante dos fatos acima expostos, deve-se elaborar o "empilhamento" dos contratos de aquisição de energia da distribuidora ao longo do ano civil, a fim de apurar o montante de sobrecontração repassável às tarifas dos consumidores finais de energia.

A ilustração a seguir exemplifica um caso onde a distribuidora fez a sazonalização de seus contratos ao longo do ano civil, já utilizando os critérios de "empilhamento" dos mesmos, onde as siglas CLA, GDCP e GDDV significam Contratos de Leilões de Ajuste, Geração Distribuída de Chamada Pública e Geração Distribuída de Desverticalização, respectivamente.

É importante ressaltar na ilustração a seguir que a carga real da distribuidora (Carga CCEE) distribuída ao longo do ano resultou em meses onde houve sobra de energia, bem como meses em que houve déficit de energia, em função da sazonalização dos contratos ao longo do ano civil. Por esse motivo, em alguns meses do ano a distribuidora teve que vender ou comprar energia no mercado spot.

Além disso, é importante frisar que o requisito regulatório, ou carga regulatória ${ }^{6}$, da distribuidora é menor do que a carga real (Carga CCEE), o que ocasionará à empresa uma parcela que não terá custo de aquisição de energia repassada às tarifas dos consumidores finais.

\footnotetext{
${ }^{6}$ Carga Regulatória da empresa é definida pela ANEEL como o mercado faturado da distribuidora, em determinado mês, adicionando às perdas regulatórias reconhecidos pelo Regulador (\% de Perdas Técnicas $+\%$ de Perdas Comerciais)
} 


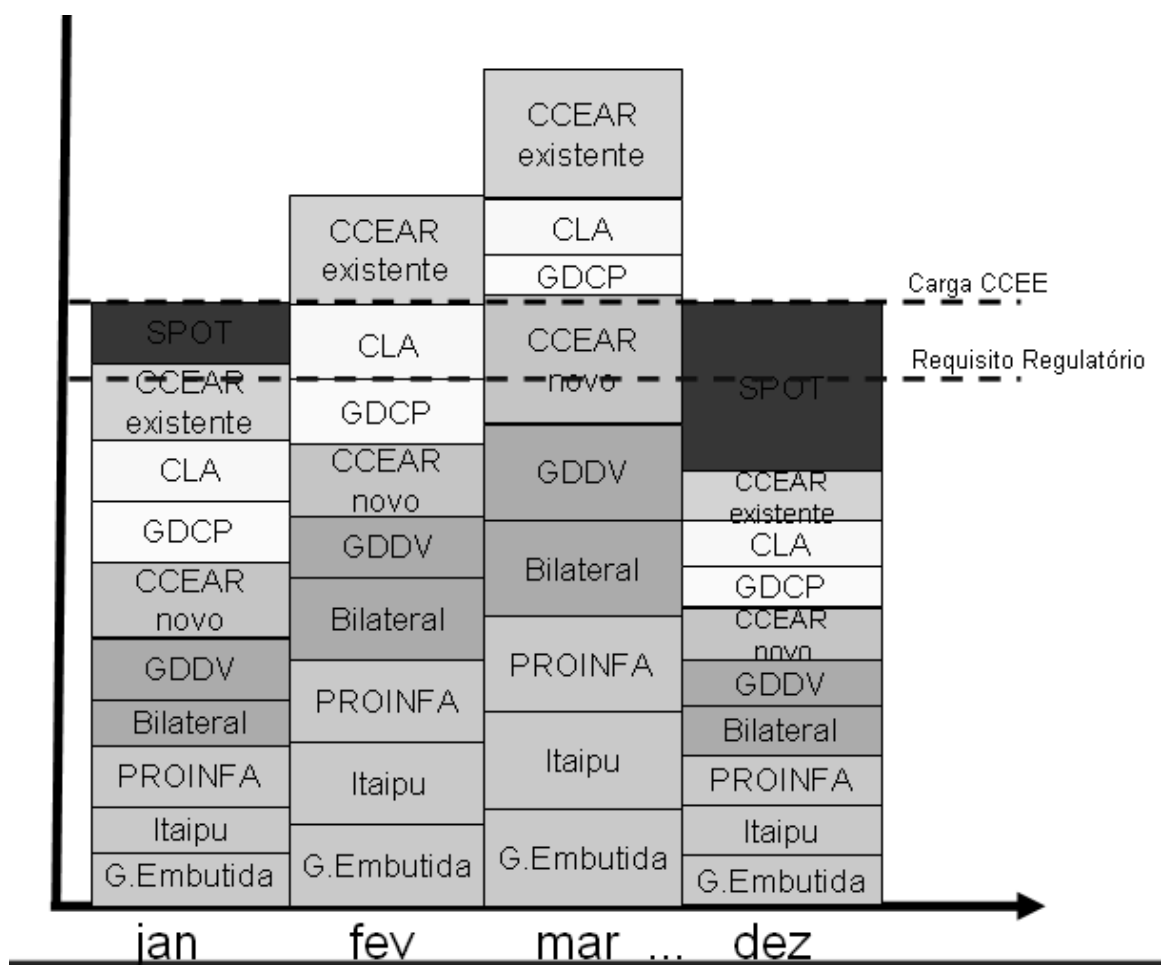

Fonte: CCEE, 2008

Figura 16 - Sazonalização de Contratos

Como existem sobras e déficits de energia ao longo do ano para a distribuidora exemplificada, deve ser efetuado um acerto financeiro da sazonalização dos contratos, garantindo assim a neutralidade no repasse dos custos relativos à compra de energia.

Assim, as sobras de energia da distribuidora ao longo do ano devem ser alocadas aos déficits, de forma proporcional a quantidade e aos meses em que houve sobras de energia. 


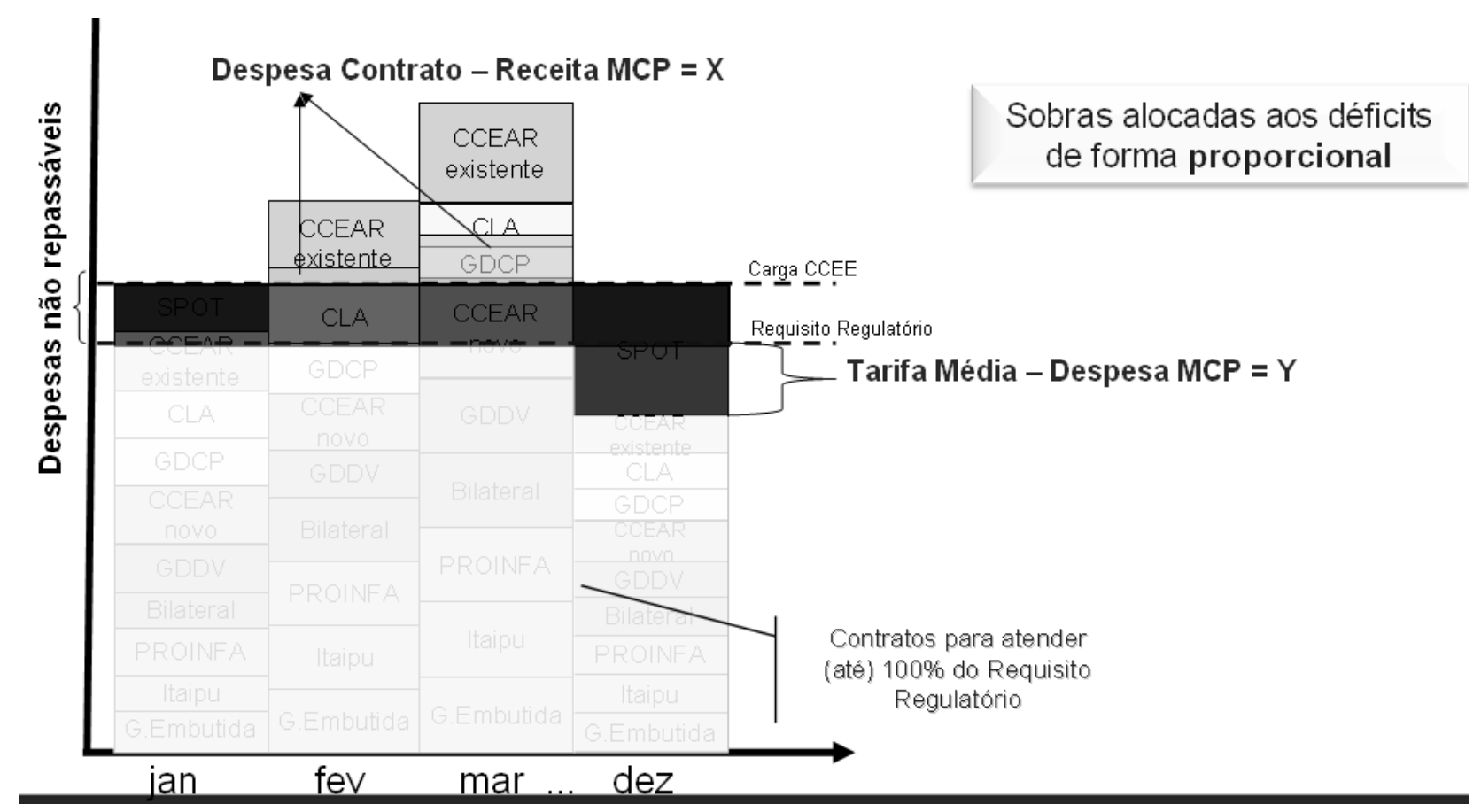

Fonte: CCEE, 2008

Figura 17 - Repasse da Sobrecontratação de energia

As sobras de energia, nos meses em que houve, geraram uma receita do mercado de curto prazo à distribuidora (Receita MCP). De maneira análoga, os déficits de energia geraram uma despesa no mercado de curto prazo (Despesa MCP). Esses resultados devem levar em consideração as tarifas médias contempladas (podem ser diferentes entre os meses em função da data de reajuste das distribuidoras), os preços dos contratos que compõem as sobras decorrentes da sazonalização e os PLDs médios da distribuidora, registrados nos meses em que houve as respectivas sobras e déficits, no sentido de neutralizar os efeitos destas variáveis.

Após definidos os contratos que vão compor as sobras contratuais, consideramse os demais contratos para o atendimento do mercado real da distribuidora. Há que se ressaltar que para composição do mercado regulatório deverão ser considerados no "empilhamento" primeiramente os montantes de energia proveniente do PROINFA, ITAIPU e contratos bilaterais anteriores a Lei ํㅜ 10.848, 
de 2004. O restante será composto pelos volumes contratados após da Lei № 10.848, de 2004, de forma ponderada.

Assim, o resultado final do repasse dos custos de aquisição de energia referente a sazonalização dos contratos seria a composição das receitas e despesas oriundas da sazonalização dos contratos, exemplificado através da subtração da variável $X$ pela variável $Y(X-Y)$ da figura acima.

Por fim, as sobras finais de energia seriam repassadas às tarifas dos consumidores finais de energia limitado a $3 \%$ da carga regulatória da distribuidora, distribuídos proporcionalmente nos meses em que houve a sobra de energia e valoradas pela diferença entre o preço do contrato e o PLD médio das distribuidoras do respectivo mês de apuração.

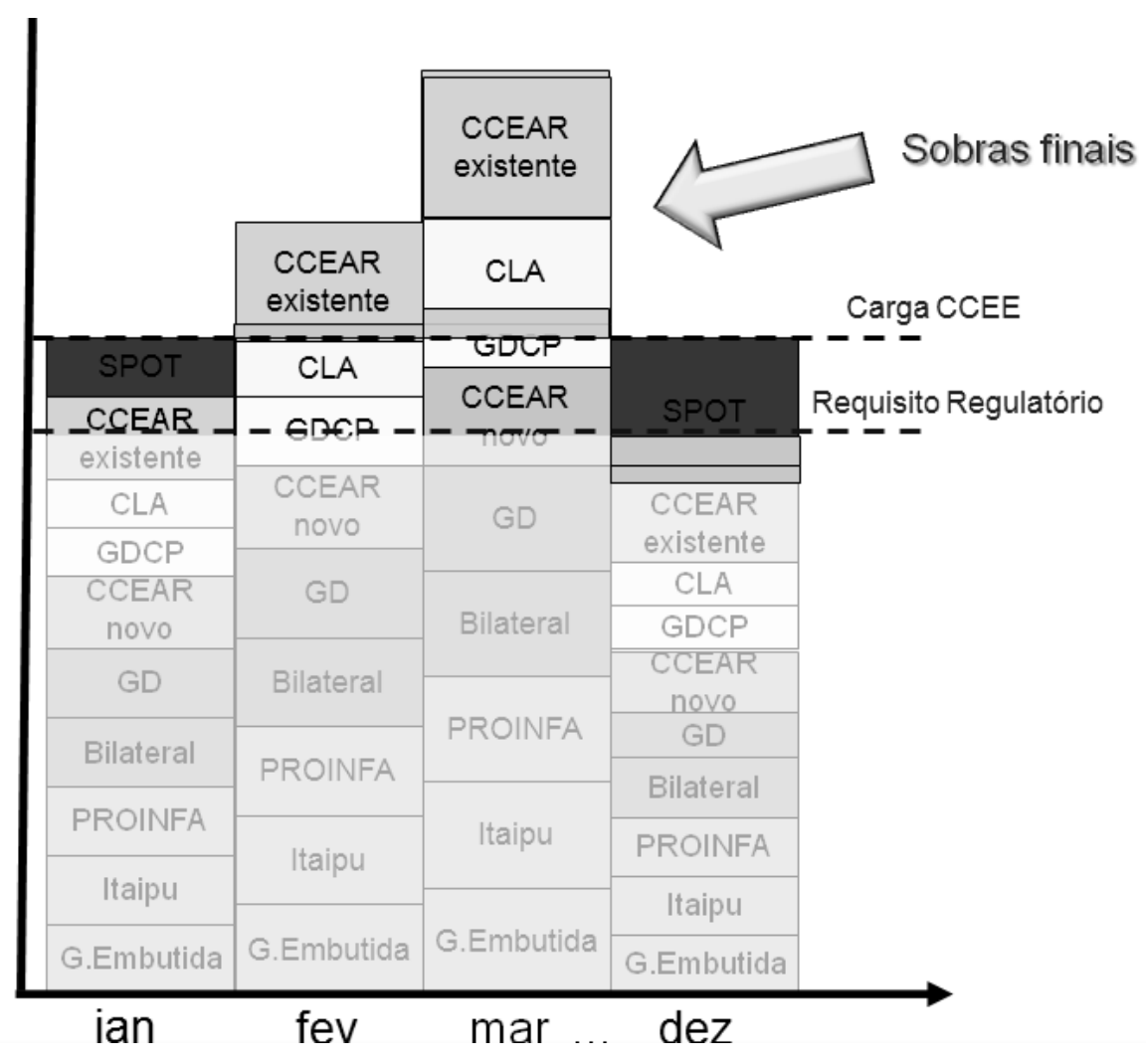

Fonte: CCEE, 2008

Figura 18 - Sobras Finais de Energia 
O valor final a ser repassado às tarifas dos consumidores finais de energia, referente à sobrecontratação de energia, pode ser obtido a partir da fórmula a seguir.

Re passe da Sobrecontratação $=3 \% C \arg a \operatorname{Re}$ gulatória $x\left(\operatorname{Pr} e c ̧ o_{\text {Contrato }}-P L D_{\text {Distribuidoras }}\right)$

Equação 3 - Repasse da Sobrecontratação

onde:

Repasse da Sobrecontratação $=$ montante financeiro a ser repassado às tarifas dos consumidores finais de energia elétrica;

3\% Carga Regulatória = limite, em MWh, do montante de energia a ser repassado às tarifas dos consumidores finais de energia elétrica;

Preço Contrato preço pago pela distribuidora referente ao contrato em questão;

PLD Distribuidora $=$ PLD médio das distribuidoras do respectivo mês de apuração.

\subsection{A CONTA DE COMPENSAÇÃO DE VARIAÇÃO DE VALORES DE ITENS DA PARCELA “A"- CVA}

Com o objetivo de registrar as variações ocorridas no período entre reajustes tarifários, dos valores dos itens de custo da "Parcela A", de que tratam os contratos de concessão de distribuição de energia elétrica, foi criada a Conta de Compensação de Variação de Valores de Itens da "Parcela A" - CVA, para efeito de cálculo da revisão ou do reajuste da tarifa de fornecimento de energia elétrica. 
A CVA foi criada pela Medida Provisória no 2.227, de 2001, e instituída pela Portaria Interministerial no 25, de 2002. Dessa forma, as variações de valores dos itens que compõem a "Parcela A", referente a revisão e reajuste tarifário, podem ser compensadas através da CVA.

Diante desse contexto, a Resolução Normativa ANEEL $n^{\circ}$ 153, de 14 de março de 2005, estabelece a CVA energia, que detecta as diferenças de preços relativas à energia elétrica comprada por meio de contratos firmados antes e posteriormente à Lei no 10.848 , de 15 de março de 2004, ocorridas durante o período de referência da concessionária. Isso ocorre pois existem preços que se alteram fora da data de reajuste. O próprio MCSD "ex-ante" requer a aplicação da CVA, uma vez que os contratos cedidos mantêm a data de aniversário da distribuidora cedente.

Assim, a CVA de energia mensal pode ser obtida como sendo o produto do montante de energia elétrica constante da fatura mensal para pagamento do custo de aquisição de energia elétrica, e a diferença entre o Preço Praticado e o Preço Considerado no Reajuste, onde o Preço Praticado é o preço efetivamente praticado para cada contrato, obedecendo-se as regras de repasse às tarifas dos consumidores finais, e Preço Considerado no Reajuste é o preço médio de aquisição de energia elétrica considerado no período de referência do reajuste tarifário do ano anterior.

Recentemente houve uma adequação do cálculo da CVA energia nova metodologia de cálculo de sobrecontratação. Essa adequação previu a criação de um fator redutor (Fator $\mathrm{K}$ ) dos montantes mensais faturados para ajustá-los à necessidade de atendimento de $100 \%$ da carga regulatória em cada mês, em consonância com o critérios de priorização de contratos.

Como pode ser observado nesse tópico, a CVA é um item de extrema importância no processo de repasse dos custos de sobrecontração de energia das distribuidoras. 


\subsection{TRATAMENTO DAS PERDAS REGULATÓRIAS}

Para que se entenda melhor o tratamento dado as Perdas Regulatórias no que tange ao repasse dos custos de aquisição de energia elétrica, é importante ressaltar algumas definições:

- Mercado Faturado: Montante de energia elétrica faturado pela concessionária ou permissionária de distribuição no ano civil que antecede o reajuste tarifário em processamento;

- Perdas Regulatórias: Montante de energia elétrica correspondente à aplicação, ao Mercado Faturado, do percentual regulatório de perdas elétricas definido pela ANEEL na última revisão tarifária periódica;

- Carga Real ou Requisito de Energia: Montante anual de energia elétrica composto pelo somatório do Mercado Faturado com as Perdas Elétricas Reais;

- Carga Regulatória = Mercado Faturado somado às Perdas Regulatórias

Essas definições são importantes, pois o repasse dos custos de aquisição de energia elétrica é efetuado em função do Requisito Regulatório. Ocorre que o Requisito Regulatório é composto por duas (2) parcelas: o Mercado Faturado e as Perdas Regulatórias.

Dessa forma, os agentes de distribuição são induzidos pela legislação vigente a buscarem a eficiência no que tange a redução de perdas, pois caso as perdas reais sejam maiores que as perdas regulatórias, a distribuidora não será autorizada a repassar às tarifas dos consumidores finais todo o custo associado às perdas de energia elétrica. 


\section{PENALIDADES}

O novíssimo modelo do setor elétrico estabeleceu a obrigatoriedade dos agentes de distribuição garantirem o atendimento a $100 \%$ de seus mercados através de contratos de compra de energia registrados e homologados pelo órgão regulador.

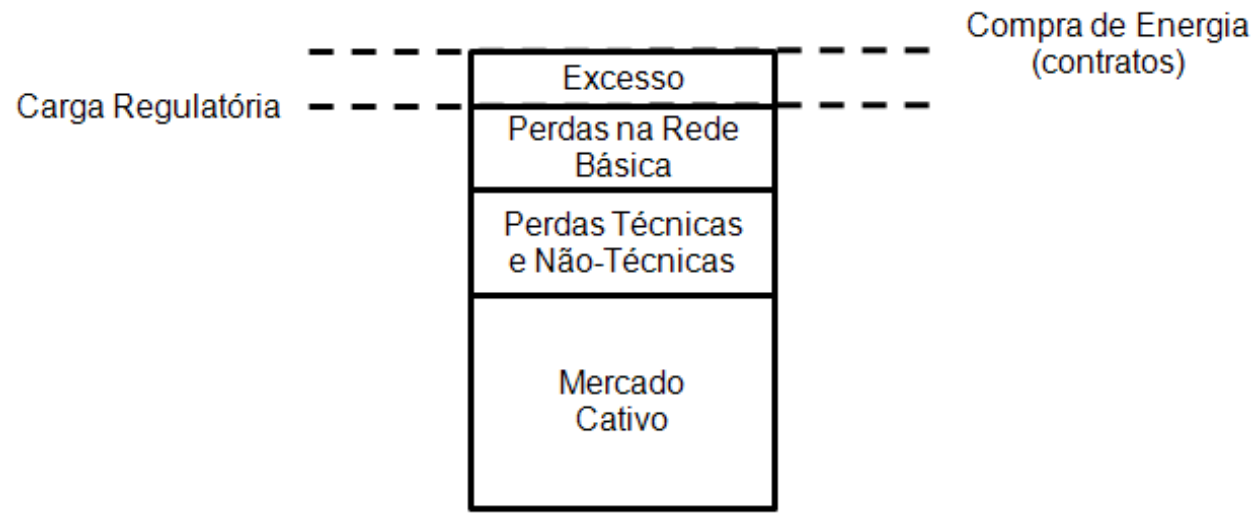

Figura 19 - Atendimento a $100 \%$ da Carga Regulatória

Para efeito de penalidades, o conceito é o mesmo, no entanto, o comparativo deve ser feito com a Carga Real, ao invés da Carga Regulatória.

Com relação as penalidades previstas na regulamentação, o Decreto 5163, de 30 de Julho de 2004, em seu Artigo 3으, § 3ํ, prevê o seguinte:

“..§ $3^{\circ}$ As penalidades por descumprimento do previsto nos incisos do caput do art. $2^{\circ}$, sem prejuízo da aplicação das disposições vigentes relativas à matéria, terão o seguinte tratamento:

I - para a obrigação prevista no inciso I daquele artigo, as penalidades serão aplicadas a partir da data da publicação deste Decreto; e

II - para as obrigações previstas nos incisos II e III daquele artigo, as penalidades serão aplicáveis a partir de janeiro de 2006, observado o disposto no $\S 22^{\circ}$."

Dessa forma, os distribuidores estão sujeitos a penalidades pela não contratação da totalidade de sua carga através de contratos, apurados mensalmente pela CCEE. 
Além da penalidade descrita, os distribuidores podem ser penalizados de outra maneira, como a limitação do repasse dos custos de aquisição de energia aos consumidores finais. Essa forma não é uma penalidade na acepção da palavra, mas não deixa de ser uma forma de penalizar a distribuidora pela sua má gestão e ineficiência na contratação do seu mercado.

\subsection{CONCEITOS}

Os conceitos envolvidos nas penalidades a serem apuradas e aplicadas aos agentes distribuidoras estão relacionados principalmente à contratação de energia.

A má utilização dos mecanismos de mitigação de riscos de mercado pode levar a distribuidora a não conseguir repassar ao consumidor final todos os custos referentes a aquisição de energia. Isso seria uma forma de penalizar a distribuidora pela ineficácia na contratação para atendimento ao seu mercado, mas não é esse tipo de penalidade que será avaliado nesse capítulo.

A penalidade a que se refere é a penalidade a ser aplicada ao distribuidor no caso do não atendimento da totalidade do seu mercado, pois o simples fato de não repassar as tarifas dos consumidores finais de energia os custos relativos a sobrecontratação de energia acima do limite de 103\% já é por si só uma penalidade imposta ao agente distribuidor.

Em linhas gerais pode-se dizer que com a legislação vigente, os agentes distribuidores devem atender a $100 \%$ do seu mercado, através da aquisição de contratos de compra de energia no ACR homologados pela Aneel e registrados na CCEE, ou ainda através dos resultados obtidos nas trocas do MCSD. 
Tendo em vista essa obrigatoriedade da legislação, o conceito de penalidade baseia-se no valor apurado inferior a $100 \%$ da carga verificada do agente. Esse cálculo é efetuado mensalmente pela CCEE, porém a aplicação da penalidade apurada é realizada todo mês de janeiro, sendo considerado no cálculo os 12 meses precedentes, ou seja, o ano civil anterior.

O montante apurado é valorado ao Preço de Referência para Penalização dos Distribuidores (PREF_DISm), o que resultará na penalidade apurada e posteriormente aplicada ao agente de distribuição.

Na próxima seção será dado um detalhamento maior a penalidade apurada aos distribuidores.

\subsection{CRITÉRIOS DE APURAÇÃO}

A insuficiência de cobertura de consumo de cada distribuidora será considerada o valor apurado inferior a $100 \%$ do seu mercado. Essa apuração ocorre durante todos os meses do ano corrente, e os agentes de distribuição são comunicados dos valores apurados. No entanto, exceto para o mês de janeiro, para os demais meses é efetuada apenas a apuração dos montantes, não sendo aplicadas penalidades sobre esses montantes. Isso serve para que os distribuidores façam o acompanhamento mensal do nível de insuficiência ao qual estão sujeitos.

Ao chegar o mês de janeiro de cada ano, é realizada a apuração da insuficiência de cobertura de consumo mensal com base na média dos doze meses precedentes ao mês de apuração dos consumos medidos referenciados ao centro de gravidade do submercado do agente de distribuição, e dos montantes contratados em qualquer submercado. Para composição do lastro de cobertura de consumo do distribuidor são considerados os contratos de compra, a quantidade declarada não realizada e o MCSD. 
Para fins de verificação do limite de contratação, a venda de energia elétrica registrada na CCEE relativa aos contratos é tratada como atendimento ao consumidor final do agente vendedor, sendo considerados como consumo e não como venda.

A figura abaixo ilustra o procedimento descrito.

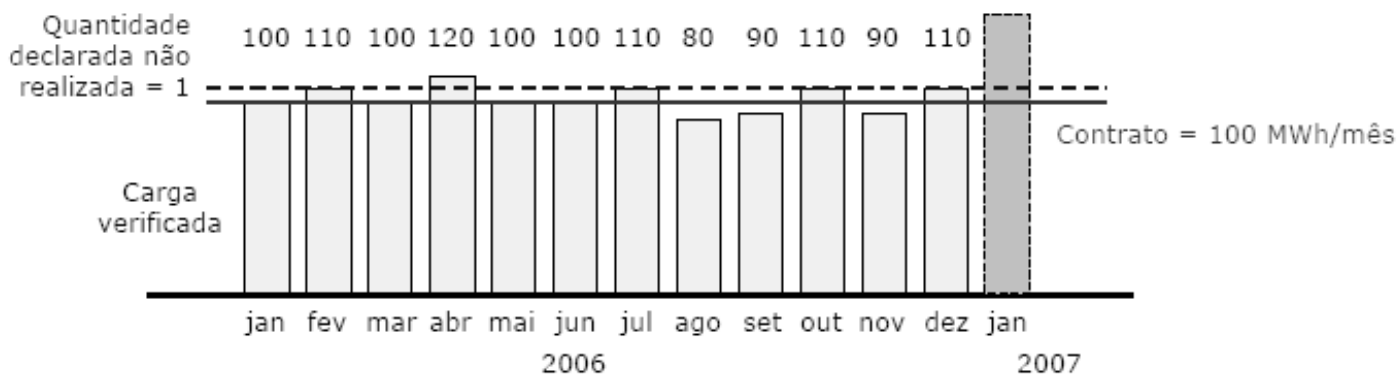

Figura 20 - Insuficiência de Cobertura de Consumo

No exemplo acima , o mês de apuração é janeiro de 2007, cujo período de apuração para verificação da insuficiência de cobertura de consumo é de janeiro/2006 a dezembro/2006.

O total de energia consumida nesse período foi de $1.220 \mathrm{MWh}$, e o total de energia contratada foi de 1.200 MWh. Considerando que a energia proveniente do processamento do MCSD foi de $3 \mathrm{MWh}$, e que a quantidade de Energia Declarada Não Realizada ${ }^{7}$ foi de $12 \mathrm{MWh}$, o lastro para cobertura de consumo do distribuidor é de 1.215 MWh.

Sob essas condições, pode-se identificar que o nível de insuficiência de cobertura de consumo do distribuidor é de $5 \mathrm{MWh}$. Essa insuficiência deve ser valorada a um determinado preço. Esse preço é calculado levando-se em consideração o

\footnotetext{
${ }^{7}$ Energia Declarada Não Realizada refere-se à quantidade de energia elétrica declarada pelo agente de distribuição e não contratada no respectivo leilão, conforme definição do parágrafo $5^{\circ}$, artigo 36, do Decreto oㅜ 5.911, de 27 de setembro de 2006. Também é conhecida no mercado de energia como "Compra Frustrada".
} 
Valor Anual de Referência (VR e VRA), e o preço médio de liquidação das diferenças das distribuidoras.

O VR deve ser calculado considerando, a média ponderada entre os valores médios de aquisição da energia, e as quantidades totais de energia, ambos relativos aos leilões de compra de energia elétrica proveniente de novos empreendimentos de geração realizados nos anos de "A-5" e "A-3"

Para os anos de 2005, 2006 e 2007, o VR considerado foi o valor máximo de aquisição de energia proveniente de empreendimentos existentes, nos leilões realizados em 2004 e 2005, para início de entrega naqueles anos. Para os anos de 2008 e 2009, deverá ser calculado considerando que o VR será o valor médio ponderado de aquisição e energia proveniente de novos empreendimentos de geração, nos leilões realizados nos anos de 2005 e 2006, para início de entrega naqueles anos. O VRA será considerado o VR do ano anterior.

O cálculo do preço médio das distribuidoras é feito de forma análoga ao cálculo do preço médio de liquidação das diferenças, considerando apenas os agentes distribuidores. Esse preço médio das distribuidoras é calculado e apurado mensalmente, no entanto, apenas a título informativo, para que os agentes distribuidores possam acompanhar a sua possível insuficiência de contratação ao longo do ano civil.

No mês de janeiro, é efetuado o cálculo acima citado, porém, analisando o histórico de 12 meses do agente, de forma análoga a apuração de penalidades quanto à cobertura de consumo do agente. É importante ressaltar que o cálculo do preço médio das distribuidoras é efetuado considerando apenas o consumo dos agentes distribuidores, bem como o PLD médio de cada mês.

O preço a ser utilizado para valorar a insuficiência de cobertura contratual será o maior valor entre o preço médio das distribuidoras e o VRA.

Apenas para finalizar o exemplo de apuração de penalidades, será utilizado o preço médio das distribuidoras de $\mathrm{R} \$ 54,65$ / MWh, e o VRA igual a $R \$ 69,98$ / 
MWh. Dessa forma, o valor a ser considerado para valorar a insuficiência de cobertura contratual será o VRA (R\$69,98 / MWh).

Finalizando o cálculo, a penalidade por insuficiência de cobertura de consumo aplicada ao agente distribuidor será de $\mathrm{R} \$ 349,90$.

\subsection{REPASSE ÀS TARIFAS}

Conforme descrito no $\S 4^{\circ}$ do artigo $3^{\circ}$ do decreto 5.163, de 30 de Julho de 2004 , as receitas resultantes da aplicação de penalidades serão revertidas à modicidade tarifária no Ambiente de Contratação Regulada - ACR.

Quando uma distribuidora é penalizada por insuficiência de cobertura de consumo, a energia necessária para atender a totalidade da sua carga deve ser adquirida no mercado de curto prazo da CCEE.

Essa energia adquirida pode ser repassada aos consumidores finais levando-se em consideração o menor valor entre o preço de liquidação das diferenças (PLD) calculado mensalmente pela CCEE com base no custo marginal de operação, e o Valor de Referência (VR).

Dessa forma, as distribuidoras são induzidas a contratarem energia de forma eficiente, minimizando assim os riscos de mercado associados a penalidades por insuficiência de cobertura de consumo.

A figura abaixo ilustra bem as penalidades associadas ao nível de contratação da distribuidora. 


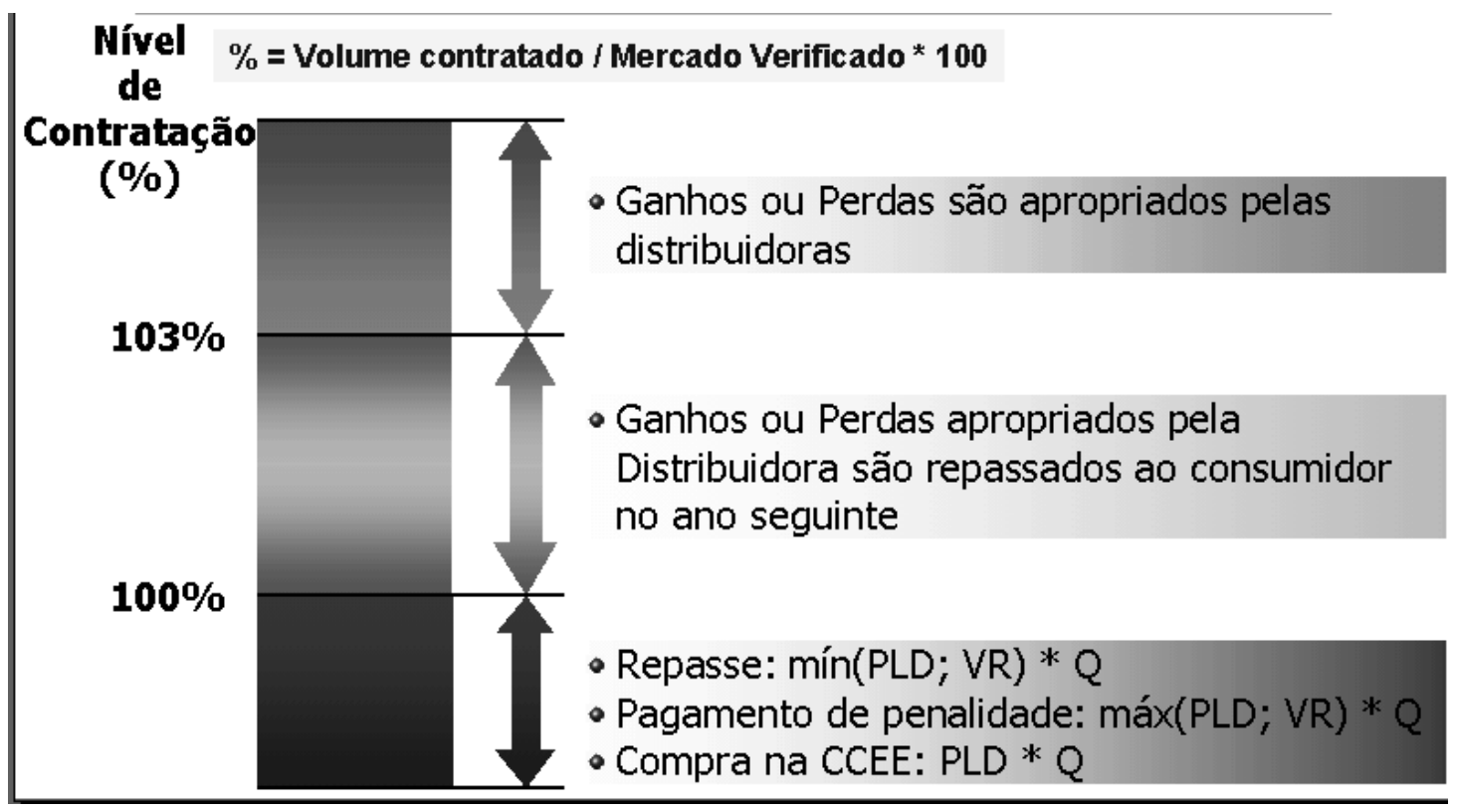

Figura 21 - Níveis de Contratação das Distribuidoras

A partir da figura, é possível notar que o nível ótimo de contratação situa-se na faixa compreendida entre $100 \%$ e $103 \%$, pois nessa faixa todos os custos associados a aquisição de energia são inteiramente repassados as tarifas dos consumidores finais de energia, desde que respeitadas as restrições quanto ao volume de contratação.

Já na faixa acima dos 103\% (sobrecontratação), a distribuidora apropria para si os custos adicionais com a aquisição de energia, não sendo permitido o seu repasse aos consumidores finais.

Por fim, se a distribuidora ficar situada abaixo da faixa dos $100 \%$ (subcontratada), pode-se dizer que a distribuidora será duplamente penalizada, pois além de pagar a penalidade prevista na legislação vigente (máximo valor entre PLD e VR, multiplicado pela insuficiência de lastro), o distribuidor terá o direito de repassar as tarifas dos consumidores finais somente a quantidade de energia contratada valorada ao mínimo entre o PLD e o VR, ou seja, o distribuidor repassa aos consumidores finais o montante de energia ao menor preço, e paga penalidade ao maior preço. 
Através desses mecanismos, o atual modelo do setor elétrico brasileiro induz 0 agente distribuidor de energia a sempre manter-se sobrecontratado, indicando assim sempre a necessidade de expansão do parque gerador de energia elétrico brasileiro. 


\section{ESTUDO DE CASO}

A partir de todos os conceitos apresentados ao longo dessa dissertação, pretende-se, nesse capítulo, elaborar algumas simulações de contratação de energia por uma distribuidora típica, dando um enfoque específico no repasse dos custos de aquisição de energia às tarifas dos consumidores finais, através de um simulador elaborado em planilha eletrônica.

Dessa forma, pretende-se concluir que alguns dos mecanismos de mitigação de riscos de mercado já descritos nesse trabalho podem ser extremamente danosos a uma empresa distribuidora se utilizados de forma ineficaz, e podem ser extremamente úteis a essa mesma empresa se utilizado de maneira inteligente e eficaz.

\subsection{CARACTERÍSTICAS DO SIMULADOR}

Para simular diferentes condições mercadológicas, foi utilizado a ferramenta Solver, disponível no programa Excel do Windows. Essa ferramenta permite ao usuário simular diversos cenários de estudo, bem como apresentar o melhor resultado para uma dada função objetivo do problema e suas restrições.

Nos cenários a serem analisados, a função objetivo a ser otimizada é o repasse dos custos de aquisição de energia às tarifas dos consumidores finais, dada pela seguinte formulação algébrica:

$$
\max z=\sum_{\text {ano }}\left(\sum_{\text {leiläo }} \operatorname{Re} \text { passe }-\sum_{\text {leilão }} \text { Custo }\right)
$$


onde:

$\sum_{\text {leiläo }}$ Re passe $=$ Repasse dos custos de aquisição de energia conforme limitação de volume e repasse tarifário, em cada leilão;

$\sum_{\text {leiläo }}$ Custo $=$ Custos de aquisição de energia em cada leilão.

Como nessa análise pretende-se apenas avaliar a utilização dos mecanismos de mitigação de riscos de mercado das distribuidoras, será considerada na análise que a distribuidora está $100 \%$ contratada no ano "A", ano esse que será objeto do estudo. Por esse motivo, as penalidades incorridas nas distribuidoras pela subcontratação e sobrecontratação de energia não serão objetos de análise, uma vez que se a distribuidora estiver $100 \%$ contratada, não haverá penalidade por subcontratação ou sobrecontratação.

Para essa análise, serão consideradas também as restrições de volume de contratação de energia, bem como de repasse tarifário, já apresentadas ao longo desse trabalho sob a forma de tabelas.

Por fim, será considerado que os contratos de aquisição de energia A-5 e A-3 estão no terceiro e primeiro ano de vigência, respectivamente.

Assim, temos os seguintes dados de entrada do simulador:

- Carga Regulatória (MW médio);

- Preço ( $R$ \$ / MWh): Preço de aquisição de energia, pela distribuidora, em cada modalidade de leilão, a saber:

- Leilão A-5; 
○ Leilão A-3;

○ Leilão A-1;

- Leilão de Ajuste;

- Leilão de Geração Distribuída.

As variáveis do problema serão as quantidades de energia a ser adquirida em cada modalidade de leilão de aquisição. É exatamente nessa etapa que a utilização dos mecanismos de mitigação de riscos de mercado das distribuidoras pode influenciar no repasse tarifário dos custos de aquisição de energia.

Nessa análise, não será considerada a violação dos limites de contratação de volume de energia, uma vez que essas são as variáveis do problema e já contemplam as restrições de regulamentação.

A única variável que se refere à quantidade de energia e que terá um valor fixo pré-definido será o MCSD, pois a quantidade de energia a ser adquirida pela distribuidora através desse mecanismo depende da disponibilidade de sobras no mercado. Dessa forma, esse valor deve ser inserido no simulador pelo usuário.

Por fim, o dado de saída do simulador será a diferença entre o Repasse do Custo de aquisição de energia e o custo efetivo de aquisição de energia. Esse valor deve ser o mais próximo de "zero" possível, pois assim indica que todo o custo de aquisição de energia foi repassado às tarifas dos consumidores finais. Caso contrário, a distribuidora terá um déficit no repasse dos custos. 


\subsection{ELABORAÇÃO DOS ESTUDOS}

Inicialmente, será analisado um caso simples de otimização do repasse dos custos de aquisição de energia. Como descrito anteriormente, em todos os casos há a necessidade de inserir um valor para a variável MCSD. Para que a comparação de resultados seja válida, em todos os cenários analisados o valor do MCSD será de 20 MW médios.

Da mesma maneira, o valor da carga regulatória em todos os cenários será de 500 MW médios. Por fim, os preços de aquisição de energia em cada modalidade de leilão também serão mantidos. Isso é de extrema importância para efeitos de comparação de resultados nos diversos cenários analisados.

Esse primeiro cenário pretende refletir a estratégia de contratação de energia de uma distribuidora extremamente conservadora, com aversão a riscos de mercado. Assim, espera-se o resultado obtido através dessa simulação apresente a maior contratação possível nos leilões de A-5, minimizando a necessidade da distribuidora recorrer aos mecanismos de mitigação de riscos de mercado. Dessa forma, temos o seguinte resultado para o primeiro cenário:

Tabela 4 - Cenário 1

\begin{tabular}{|c|c|c|c|c|c|c|c|}
\hline \multicolumn{2}{|c|}{ Carga Regulatória (MW medio) } & & 500,00 & & & & \\
\hline \multicolumn{2}{|c|}{ Valor de Referência - VR (R\$ / MWh) } & & 95,00 & & & & \\
\hline Produto & Quantidade (MW medio) & & MWh) & & la Energia (R\$) & $\mathbf{R e}$ & e do Custo (R\$) \\
\hline A-5 & 475,00 & $\mathrm{R} \$$ & 95,00 & $\mathrm{R} \$$ & $395.295 .000,60$ & $\mathrm{R} \$$ & $395.295 .000,60$ \\
\hline A-3 & 0,00 & $\mathrm{R} \$$ & 100,00 & $\mathrm{R} \$$ & - & $\mathrm{R} \$$ & - \\
\hline A-1 & 5,00 & $\mathrm{R} \$$ & 90,00 & $\mathrm{R} \$$ & $3.941 .999,62$ & $\mathrm{R} \$$ & $3.941 .999,62$ \\
\hline GD & 0,00 & $\mathrm{R} \$$ & 96,00 & $\mathrm{R} \$$ & - & $\mathrm{R} \$$ & - \\
\hline Ajuste & 0,00 & $\mathrm{R} \$$ & 105,00 & $\mathrm{R} \$$ & - & $\mathrm{R} \$$ & - \\
\hline MCSD & 20,00 & $\mathrm{R} \$$ & - & $\mathrm{R} \$$ & - & $\mathrm{R} \$$ & - \\
\hline TOTAL & 500,00 & & & $\mathbf{R} \$$ & $399.237 .000,22$ & $\mathbf{R} \$$ & $399.237 .000,22$ \\
\hline
\end{tabular}

Déficit de Repasse dos Custos de Aquisição de Energia

$R \$ 0,00$

A expectativa quanto ao resultado apresentado pelo simulador foi confirmada, uma vez que o resultado verificado indicou que toda a contratação de energia 
deva ser efetuada nos leilões de A-5 e de A-1, respeitando-se o limite de contratação no leilão de A-1. Isso já era esperado uma vez que o preço de aquisição de energia nesses leilões é menor que os demais, nesse estudo.

Dessa forma, todo o custo referente à aquisição de energia pode ser repassado às tarifas dos consumidores finais. Esse seria o "mundo ideal" para as distribuidoras, mas na prática, não é bem assim que o mercado se comporta, pois existem variações de consumo, variáveis exógenas, etc.

Podemos concluir que para o primeiro caso analisado, foram utilizados apenas dois (2) mecanismos de mitigação de riscos de mercado: leilões em A-1 e MCSD. Como o valor do MCSD foi fixado num determinado valor em todos os cenários para evitar distorções nos resultados, a participação nos leilões em A-1 realmente é a melhor alternativa para mitigar o risco de mercado dessa distribuidora diante desse cenário, uma vez que o custo de aquisição de energia nessa modalidade de leilão é o mais baixo dentre os custos dos outros mecanismos, garantindo assim o repasse integral do custo de aquisição.

É importante ressaltar que o repasse será integral pois as restrições de volume não foram violadas, e o custo da energia em $R \$ / M W h$ é menor que o VR.

Num segundo cenário o objetivo é simular a estratégia de contratação de uma distribuidora um pouco mais arrojada, ou seja, uma distribuidora que deixou de contratar parte de sua necessidade no leilão de A-5 para contratar em outro momento, utilizando assim alguns mecanismos de mitigação de riscos de mercado.

Nesse cenário, será simulada a situação em que o distribuidor contratou no leilão de A-5 apenas 450 MW médios, havendo portanto a necessidade adicional de contratar $50 \mathrm{MW}$ médios utilizando mecanismos de mitigação de riscos. Como o valor do MCSD será fixado em $20 \mathrm{MW}$ médios, a distribuidora deverá recorrer à algum mecanismo disponível para mitigar o seu risco de mercado no que tange o repasse dos custos de aquisição de energia somente para $30 \mathrm{MW}$ médios. 
Assim, espera-se que o simulador apresente um resultado de otimização da utilização dos mecanismos de mitigação de riscos.

O resultado obtido para esse cenário pode ser observado na tabela a seguir:

Tabela 5 - Cenário 2

\begin{tabular}{|c|c|c|c|c|c|c|c|}
\hline \multicolumn{2}{|c|}{ Carga Regulatória (MW medio) } & \multicolumn{2}{|r|}{500,00} & & & & \\
\hline \multicolumn{2}{|c|}{ Valor de Referência - VR (R\$ / MWh) } & \multicolumn{3}{|c|}{95,00} & & & \\
\hline Produto & Quantidade (MW medio) & \multicolumn{2}{|c|}{ Preco (R\$ / MWh) } & \multicolumn{2}{|c|}{ Custo da Energia (R\$) } & \multicolumn{2}{|c|}{ Repasse do Custo (R\$) } \\
\hline A-5 & 450,00 & $\mathrm{R} \$$ & 95,00 & $\mathrm{R} \$$ & $374.490 .000,00$ & $\mathrm{R} \$$ & $374.490 .000,00$ \\
\hline A-3 & 0,00 & $\mathrm{R} \$$ & 100,00 & $\mathrm{R} \$$ & - & $\mathrm{R} \$$ & - \\
\hline A-1 & 5,00 & $\mathrm{R} \$$ & 90,00 & $\mathrm{R} \$$ & $3.941 .999,62$ & $\mathrm{R} \$$ & $3.941 .999,62$ \\
\hline GD & 25,00 & $\mathrm{R} \$$ & 96,00 & $\mathrm{R} \$$ & $21.024 .000,00$ & $\mathrm{R} \$$ & $20.805 .000,00$ \\
\hline Ajuste & 0,00 & $\mathrm{R} \$$ & 105,00 & $\mathrm{R} \$$ & - & $\mathrm{R} \$$ & - \\
\hline MCSD & 20,00 & $\mathrm{R} \$$ & - & $\mathrm{R} \$$ & - & $\mathrm{R} \$$ & - \\
\hline TOTAL & 500,00 & & & $\mathbf{R} \$$ & $399.455 .999,62$ & $\mathbf{R} \$$ & $399.236 .999,62$ \\
\hline
\end{tabular}

Déficit de Repasse dos Custos de Aquisição de Energia

$(R \$ 219.000,00)$

O resultado obtido através da simulação foi a de utilizar três (3) mecanismos de mitigação de riscos de mercado: participação em leilão de A-1, aquisição através de leilões de Geração Distribuída, e MCSD.

Como o MCSD foi fixado em $20 \mathrm{MW}$ médios, os $30 \mathrm{MW}$ médios necessários para atender o mercado da distribuidora deverão ser contratados através de leilões de A-1 e de Geração Distribuída, pois são os leilões com menor custo de aquisição de energia, possibilitando assim um maior repasse dos custos de aquisição de energia às tarifas dos consumidores finais.

Assim, o resultado apontou para a contratação de $5 \mathrm{MW}$ médios através de leilões de A-1 e 25 MW Médios através de leilões de Geração Distribuída, sendo que todo o custo de aquisição de energia oriunda do leilão de A-1 deve ser integralmente repassada às tarifas dos consumidores finais. Já os custos de aquisição de energia oriunda de leilões de geração distribuída não podem ser integralmente repassados aos consumidores finais, pois nessa modalidade de contratação existe a restrição do VR para fins de repasse tarifário e, como nesse estudo o VR é menor que o preço da energia oriunda de geração distribuída, uma pequena parcela dos custos não pode ser repassada aos consumidores finais. 
Mesmo com um resultado negativo, a contratação de energia oriunda de geração distribuída mostrou-se se o melhor mecanismo de mitigação de risco de mercado para a distribuidora, no estudo em questão.

Assim, pode-se concluir que a estratégia de contratação dessa distribuidora foi um pouco equivocada, pois a mesma deixou de contratar energia suficiente no leilão de A-5, na expectativa de se beneficiar de alguma situação conjuntural mais favorável , o que de fato ao aconteceu. No entanto, diante do cenário exposto, a empresa utilizou de maneira eficaz os mecanismos de mitigação, pois realmente a contratação de energia através de leilões de geração distribuída e leilões de A-1 mostraram ser as alternativas menos danosas à empresa.

No entanto, pode ser que a distribuidora não utilize de maneira adequada as ferramentas que possui para planejar a sua contratação de energia, utilizando os mecanismos de mitigação de riscos indevidos.

Isso pode ocasionar um resultado financeiro negativo à empresa no que tange 0 repasse dos custos de aquisição de energia.

Para exemplificar essa situação, foi elaborado mais um cenário de estudo de uma distribuidora mais arrojada que utilizou de maneira equivocada um dos mecanismos disponíveis para mitigar riscos de mercado. Com esse cenário pretende-se demonstrar o impacto financeiro da utilização indevida de um mecanismo.

Assim, para esse cenário será considerado o fato de que a distribuidora contratou $450 \mathrm{MW}$ médios no leilão de $\mathrm{A}-5$, a exemplo do cenário anterior. O valor do MCSD também será fixado em $20 \mathrm{MW}$ médios, de maneira análoga ao cenário anterior. No entanto, será simulado o fato de que, nesse caso especificamente, a distribuidora utilizou erroneamente a contratação de apenas $10 \mathrm{MW}$ médios em leilões de geração distribuída ao invés de um montante maior, como sugerido no cenário anterior. 
Dessa forma, para ficar totalmente contratada, como exige a legislação vigente, a distribuidora teria que contratar os outros $20 \mathrm{MW}$ médios de outra maneira.

O resultado esperado desse cenário é que a contratação de energia utilizando outros mecanismos de mitigação de riscos seja otimizada a fim de minimizar as perdas referente ao repasse de custos de aquisição de energia, uma vez que a estratégia de contratação adotada pela empresa não foi a mais adequada.

A tabela a seguir ilustra o panorama de contratação descrito anteriormente.

Tabela 6 - Cenário 3

\begin{tabular}{|c|c|c|c|c|c|c|c|}
\hline \multicolumn{2}{|c|}{ Carga Regulatória (MW medio) } & \multicolumn{3}{|c|}{500,00} & & & \\
\hline \multicolumn{2}{|c|}{ Valor de Referência - VR (R\$ / MWh) } & \multicolumn{3}{|c|}{95,11} & & & \\
\hline Produto & Quantidade (MW medio) & \multicolumn{2}{|c|}{ Preco (R\$ / MWh) } & \multicolumn{2}{|c|}{ Custo da Energia (R\$) } & \multicolumn{2}{|c|}{ Repasse do Custo (R\$) } \\
\hline A-5 & 450,00 & $\mathrm{R} \$$ & 95,00 & $\mathrm{R} \$$ & $374.490 .000,00$ & $\mathrm{R} \$$ & $374.490 .000,00$ \\
\hline A-3 & 10,00 & $\overline{\mathrm{R} \$}$ & 100,00 & $\mathrm{R} \$$ & $8.760 .000,00$ & $\mathrm{R} \$$ & $8.331 .521,74$ \\
\hline A-1 & 5,00 & $\overline{\mathrm{R} \$}$ & 90,00 & $\mathrm{R} \$$ & $3.941 .999,62$ & $\mathrm{R} \$$ & $3.941 .999,62$ \\
\hline GD & 10,00 & $\mathrm{R} \$$ & 96,00 & $\mathrm{R} \$$ & $8.409 .600,00$ & $\mathrm{R} \$$ & $8.331 .521,74$ \\
\hline Ajuste & 5,00 & $\mathrm{R} \$$ & 105,00 & $\mathrm{R} \$$ & $4.599 .000,00$ & $\mathrm{R} \$$ & $4.165 .760,87$ \\
\hline MCSD & 20,00 & $\overline{\mathrm{R} \$}$ & - & $\mathrm{R} \$$ & - & $\mathrm{R} \$$ & - \\
\hline TOTAL & 500,00 & & & $\mathbf{R} \$$ & $400.200 .599,62$ & $\mathbf{R} \$$ & $399.260 .803,96$ \\
\hline
\end{tabular}

Déficit de Repasse dos Custos de Aquisição de Energia

$(\mathrm{R} \$ 939.795,65)$

O resultado obtido pelo simulador indicou a necessidade de contratação de 10 MW médios em leilões de A-3, $5 \mathrm{MW}$ médios em leilões de A-1, e outros $5 \mathrm{MW}$ médios em leilões de Ajuste.

Como houve a necessidade de contratação de energia no leilão de A-3, o valor do VR sofreu uma pequena alteração, pois este parâmetro representa a média ponderada dos custos de aquisição de energia nos leilões de A-3 e A-5. Isso pode impactar diretamente no repasse tarifário dos custos de aquisição de energia, pois conforme demonstrado ao longo dessa dissertação, a maior parte dos mecanismos de mitigação de riscos de mercado tem o repasse dos custos de aquisição de energia limitado ao VR.

Quanto aos mecanismos de mitigação utilizados nesse cenário, é importante notar que todas as formas de contratação de energia em leilões foram utilizadas. 
Isso demonstra que não basta apenas efetuar uma boa contratação nos leilões de A-5 e esperar que todo custo de aquisição de energia seja repassado aos consumidores finais, pois as variações conjunturais e de mercado podem fazer com que a distribuidora se utilize de mecanismos de mitigação de riscos que não estavam previstos em sua estratégia de contratação.

Pode-se notar que com esse cenário, o déficit de repasse dos custos de aquisição de energia aumenta sistematicamente, atingindo cerca de $\mathrm{R} \$ 1$ milhão. Esse fato se dá basicamente porque existe uma limitação quanto ao repasse tarifário, conforme apresentado ao longo desse trabalho. Para os casos de leilões de Ajuste e de Geração Distribuída existe um limitador do repasse tarifário, que é o VR. Qualquer custo de aquisição oriundo desses leilões superior ao VR não será repassado ao consumidor final.

Da mesma maneira, existe um limitador do repasse tarifário de energia adquirida de leilões de A-3. Esse limitador é o VR, e é válido apenas nos 3 primeiros anos do contrato. A partir do $4^{\circ}$ ano o repasse é integral. Como nesse estudo foi considerado que o contrato de leilão A-3 está no primeiro ano de vigência, o limitador é o VR.

Pelo simples fato de utilizar de maneira equivocada os mecanismos de mitigação de riscos, a distribuidora teve uma perda de aproximadamente $\mathrm{R} \$ 800$ mil em um ano, comparando o segundo com o terceiro cenário.

Para comparar melhor os resultados obtidos, foi elaborada uma figura com as situações simuladas nesse estudo. Essa figura exemplifica bem o resultado financeiro das diversas estratégias de contratação das distribuidoras, bem como o impacto referente à utilização indevida de alguns mecanismos de mitigação de riscos de mercado pelas distribuidoras. 


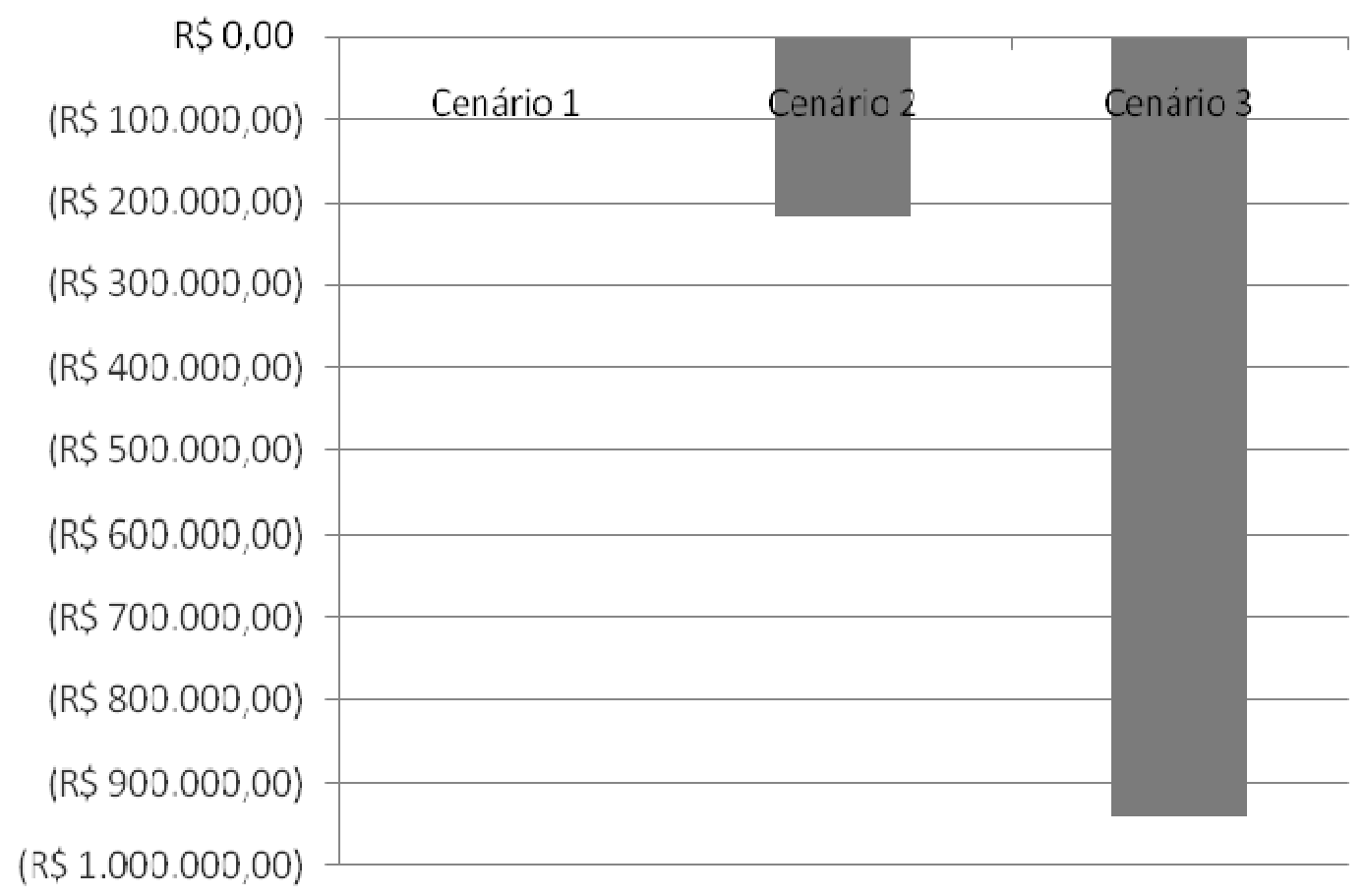

Figura 22 - Comparativo entre Cenários

Para melhor comparar os resultados obtidos deve-se ter o entendimento de que 0 cenário 1 representa uma distribuidora conservadora, que contratou a maior parte de sua necessidade nos leilões de A-5. O cenário 2 representa uma distribuidora menos eficiente em sua projeção de mercado e estabelecimento do montante adequado de contratação no futuro mais distante e que não contratou a totalidade de sua necessidade nos leilões de A-5, tendo que se defender das penalidades utilizando alguns mecanismos de mitigação de riscos de mercado. $O$ cenário 3 representa uma distribuidora semelhante àquela do cenário 2 , mas que utilizou de maneira equivocada um dos mecanismos de mitigação de risco de mercado.

As diferenças entre os resultados obtidos em cada cenário de estudo indica que uma utilização inadequada dos mecanismos de mitigação de riscos de mercado pode ser extremamente onerosa à empresa.

É importante ressaltar também que no estudo em questão foi considerado apenas um ano de análise, o ano "A". No dia-a-dia da distribuidora, a contratação de energia, bem como o nível de contratação e a conseqüente utilização de 
mecanismos de mitigação de riscos de mercado, ocorrem em anos diferentes, com horizontes de analises de longo prazo, o que torna bem mais complexo o processo de utilização de mecanismos de mitigação de riscos.

\subsection{ANÁLISE DOS RESULTADOS OBTIDOS}

A partir dos resultados obtidos pode-se verificar o impacto que a utilização dos mecanismos de mitigação de riscos de mercado podem ocasionar a uma empresa de distribuição de energia elétrica. Esses impactos podem ser positivos ou negativos, como exemplificado nos casos analisados.

Os cenários elaborados pretendem abranger uma gama não exaustiva das possibilidades existentes, mas ainda assim representativa de casos de contratação de empresas distribuidoras, mostrando que os conceitos apresentados ao longo dessa dissertação podem e devem ser utilizados pelas mesmas, a fim de evitar prejuízos inesperados e maximizar os lucros nas operações de repasse dos custos de aquisição de energia às tarifas dos consumidores finais.

O cenário 1, que representa uma empresa conservadora que contratou a maior parte de sua necessidade no leilão de A-5, parece ser o mais indicado para as empresas distribuidoras, diante dos dados do estudo. Com a utilização de apenas dois (2) mecanismos de mitigação de risco a empresa conseguiu atingir o seu objetivo, ou seja, repassar às tarifas dos consumidores finais todos os custos referentes a aquisição de energia. Essa mostrou-se ser a melhor estratégia de contratação de energia diante dos dados fornecidos.

Já no cenário 2 foi possível visualizar que uma empresa com perfil mais arrojado que a primeira utilizou de maneira eficaz dos mecanismos de mitigação de risco 
que dispunha, tendo em vista uma menor contratação de energia no leilão de A-5 por essa empresa mostrou-se ser uma estratégia equivocada.

Por fim, com o cenário 3 pode-se notar claramente qual o impacto financeiro da má utilização dos mecanismos de mitigação de riscos de mercado. Essa distribuidora também tinha um perfil mais arrojado em relação à primeira, pois contratou o mesmo montante no leilão de A-5 que a distribuidora do cenário 2. No entanto, essa distribuidora utilizou de maneira equivocada o mecanismo de mitigação de risco de contratação de energia através de leilões de geração distribuída. Essa empresa contratou menos energia nessa modalidade de leilão do que deveria, pelo que teve que recorrer aos outros mecanismos para minimizar o seu prejuízo quanto ao repasse dos custos de aquisição de energia.

O que pode ser observado claramente é que, diante dos dados fornecidos para a elaboração dos cenários, a melhor estratégia de contratação, para esse caso, é contratar a maior quantidade possível de energia nos leilões de A-5, possibilitando assim um maior repasse dos custos de aquisição de energia, fazendo com que a distribuidora não aproprie eventuais perdas pelo não repasse integral dos custos.

Um fator importante a ser citado nessas análises é que foi considerado o risco da contratação de volume de energia, ou seja, em todos os casos estudados o volume de energia contratada não infringiu limite algum. Isso foi propositalmente colocado nos casos em estudo para mostrar que apenas uma gestão eficiente quanto aos momentos de contratação e uma análise minuciosa dos riscos associados ao repasse dos custos de aquisição de energia são suficientes para levar uma distribuidora de porte médio, como é o caso que foi analisado, do lucro ao prejuízo.

De maneira análoga, as restrições de repasse tarifário também foram consideradas nos estudos efetuados, ficando ainda mais evidente a importância da utilização eficiente dos mecanismos de mitigação de riscos de mercado das distribuidoras. 
Para a realização desses estudos, foram utilizados basicamente os dados já apresentados ao longo desse trabalho, como por exemplo as tabelas-resumo de riscos de contratação de volume de energia e de repasse tarifário, a figura indicativa dos momentos de contratação, etc. Isso posto, é importante frisar que os conceitos de mercado e de risco de mercado são de fundamental importância nesse tipo de análise, pois a partir deles podem ser traçadas estratégias vencedoras na condução e gestão das grandes corporações. 


\section{CONCLUSÕES E RECOMENDAÇÕES}

Uma das premissas do novo modelo do setor elétrico brasileiro, que é a modicidade tarifária, está diretamente relacionada ao repasse dos custos de aquisição de energia elétrica pelos distribuidores. Ao longo desse trabalho, podese notar que existem incentivos e estímulos para que as distribuidoras façam uma contratação de energia eficiente, principalmente nos leilões de energia de A-5 e nos leilões de energia de A-3, com menos freqüência.

Dessa forma, a modicidade tarifaria é uma premissa que está sendo observada e cumprida com certa eficiência e eficácia pelos distribuidores.

Outro ponto a ser destacado é que os mecanismos de mitigação de riscos de mercado das distribuidoras são utilizados com eficiência pelas empresas, tendo em vista que o repasse dos custos de aquisição de energia aos consumidores finais de energia é regulado e cuidadosamente verificado pela Aneel no processo de revisão e reajuste tarifário.

Além disso, existem penalidades às quais as distribuidoras estão sujeitas no caso de contratação ineficiente de energia, além da possibilidade de não repassar os custos da aquisição os consumidores finais, como pode ser observado nos estudos de caso desse trabalho, o que pode ocasionar resultados negativos para a empresa.

Como exemplo, podemos citar o fato de que a maioria das distribuidoras que passaram pelo processo de revisão e reajuste tarifário estavam sobrecontratadas, uma vez que a legislação exige a contratação de $100 \%$ da carga da distribudora.

Através dos cenários simulados no estudo de caso, pode-se concluir que independente do perfil de atuação da empresa, a estratégia de contratação de energia deve estar bem embasada no fato de que a utilização dos mecanismos de mitigação de riscos de mercado pelas distribuidoras são fatores fundamentais para otimizar o repasse tarifário dos custos de aquisição de energia, bem como 
corrigir eventuais equívocos nas estratégias de contratação de energia das distribuidoras.

Podemos citar ainda o fato de que os mecanismos de estímulo à contratação eficiente por parte dos agentes distribuidores tem surtido efeito também no que tange a uma outra premissa do novo modelo do setor, que é a garantia da expansão da oferta de energia. Isso pode ser verificado pelo fato de que a maioria das distribuidoras efetua a sua contratação de energia nos leilões de A-5, ficando para os leilões de A-3, A-1 e Ajuste apenas a contratação relativa a volatilidade do seu mercado de energia.

Por fim, há que se destacar e concluir que o impacto da utilização dos mecanismos de mitigação de riscos de mercado na gestão das empresas distribuidoras é muito grande, podendo levar a empresa ao sucesso ou a um período de problemas sérios. Isso pode ser observado nos estudos de caso que foram efetuados ao longo desse trabalho. 


\section{REFERÊNCIAS}

AGÊNCIA NACIONAL DE ENERGIA ELÉTRICA - ANEEL. Brasília. Apresenta informações sobre regulamentação e fiscalização do setor elétrico. Disponível em: <http://www.aneel.gov.br/>. Acesso em 10 de março de 2008.

ANEEL - Agência Nacional de Energia Elétrica. "Manual do Programa de Pesquisa e Desenvolvimento Tecnológico do Setor Elétrico" - Brasília, 2008.

ANEEL - Agência Nacional de Energia Elétrica. Nota Técnica Complementar № 047/2007, "Análise complementar das contribuições recebidas na Audiência que trata dos critérios de repasse às tarifas do consumidor final do custo de sobrecontratação de energia elétrica de até 3\%" - Brasília, 2007.

ANEEL - Agência Nacional de Energia Elétrica. Nota Técnica oㅡ 030/2003, "Informações sobre a metodologia e os conceitos adotados pela ANEEL para proceder à revisão tarifária periódica das concessionárias de distribuição de energia elétrica" - Brasília, 2003.

ANEEL - Agência Nacional de Energia Elétrica. Nota Técnica ㄲo 083/2003, "Abertura das parcelas e realinhamento das tarifas de fornecimento de energia elétrica" - Brasília, 2003.

ANEEL - Agência Nacional de Energia Elétrica. Nota Técnica no 148/2002, "Metodologia e critérios gerais para definição da base de remuneração de ativos para fins de revisão tarifária periódica das concessionárias de distribuição de energia elétrica" - Brasília, 2002.

ANEEL - Agência Nacional de Energia Elétrica. Nota Técnica № 184/2007SRE/ANEEL, que trata da segunda revisão tarifária periódica da empresa ELETROPAULO - Brasília, 2007.

ASSOCIAÇÃO BRASILEIRA DE DISTRIBUIDORES DE ENERGIA ELÉTRICA - ABRADEE. Rio de Janeiro. Apresenta informações e estudos de gestão operacional e econômico-financeira das empresas associadas, sob a ótica do distribuidor de energia elétrica. Disponível em: <http://www.abradee.org.br/>. Acesso em 15 de fevereiro de 2008.

ASSOCIAÇÃO BRASILEIRA DOS PRODUTORES INDEPENDENTES DE ENERGIA ELÉTRICA - APINE. Brasília. Apresenta informações e estudos sob a ótica do Produtor Independente de Energia Elétrica. Disponível em: $<$ http://www.apine.com.br/>. Acesso 15 de fevereiro de 2008. 
BRASIL. Decreto $n^{\circ} 5.163$, de 30 de julho de 2004. Regulamenta a comercialização de energia elétrica, o processo de outorga de concessões e de autorizações de geração de energia elétrica, e dá outras providências.

BRASIL. Decreto $\mathrm{n}^{\circ} 5.177$, de 12 de agosto de 2004. Dispõe sobre a Câmara de Comercialização de Energia Elétrica - CCEE.

BRASIL. Lei $n^{\circ} 10.847$, de 15 de março de 2004. Autoriza a criação da Empresa de Pesquisa Energética - EPE.

BRASIL. Lei $n^{\circ} 10.848$, de 15 de março de 2004. Dispõe sobre a comercialização de energia elétrica, altera as Leis nos 5.655, de 20 de maio de 1971, 8.631, de 4 de março de 1993, 9.074, de 7 de julho de 1995, 9.427, de 26 de dezembro de 1996, 9.478, de 6 de agosto de 1997, 9.648, de 27 de maio de 1998, 9.991, de 24 de julho de 2000, 10.438, de 26 de abril de 2002, e dá outras providências.

BRASIL. Lei ำ 9.074, de 07 de Julho de 1995. Estabelece normas para outorga e prorrogações das concessões e permissões de serviços públicos e dá outras providências.

BRASIL. Lei no 9.648, de 27 de Maio de 1998. Altera dispositivos das Leis no 3.890-A, de 25 de abril de 1961, no 8.666, de 21 de junho de 1993, no 8.987, de 13 de fevereiro de 1995, no 9.074, de 7 de julho de 1995, no 9.427, de 26 de dezembro de 1996, e autoriza o Poder Executivo a promover a reestruturação da Centrais Elétricas Brasileiras - ELETROBRÁS e de suas subsidiárias e dá outras providências.

BRASIL. Resolução Normativa no 109, de 26 de Outubro de 2004. Institui a Convenção de Comercialização de Energia Elétrica.

BRASIL. Resolução Normativa no 247, de 21 de Dezembro de 2006. Estabelece as condições para a comercialização de energia elétrica, oriunda de empreendimentos de geração que utilizem fontes primárias incentivadas, com unidade ou conjunto de unidades consumidoras cuja carga seja maior ou igual a $500 \mathrm{~kW}$ e dá outras providências.

BRASIL. Resolução Normativa no 255, de 06 de Março de 2007. Estabelece os critérios para repasse, às tarifas do consumidor final, do custo da sobrecontratação de energia elétrica.

CÂMARA DE COMERCIALIZAÇÃO DE ENERGIA ELÉTRICA - CCEE. São Paulo. Apresenta informações acerca do funcionamento do mercado de energia elétrica. Disponível em: <http://www.ccee.org.br/>. Acesso em 29 de março 2008. 
CEPEL. DECOMP: Determinação da Coordenação da Operação a Curto Prazo. Manual do Usuário v. 14 e Manual de Referência, 2008.

CEPEL. NEWAVE I e II: Planejamento da Operação a Longo Prazo de Subsistemas Hidrotérmicos Interligados. Manual do Usuário, Especificação Funcional e Manual de Metodologia, 2007.

DAVID, P.A.M-S.; VEIGA FILHO, A.; PEREIRA, M.V.F.; GRANVILLE, S. Formação do Preço, Atração de Investimentos e Gerenciamento de Risco no Mercado Brasileiro de Energia Elétrica. PUC. Rio de Janeiro, 2004. 134p.

EMPRESA DE PESQUISA ENERGÉTICA - EPE. Rio de Janeiro. Apresenta estudos de planejamento e de viabilidade de empreendimentos de geração, entre outros. Disponível em: <http://www.epe.gov.br/index2.htm>. Acesso em 15 de março de 2008.

ITOCAZO, F.R.; RAMOS, D.S. Comercialização de Energia Elétrica. Universidade de São Paulo. São Paulo, 2004.

MAIA, F. Desafios para as concessionárias. In.: Seminário Cenários de Energia. Curitiba, 2005.

MEDEIROS, L. de; SOUZA, R.C. Previsão do Preço Spot no Mercado de Energia Elétrica. PUC. Rio de Janeiro, 2006. 132p.

MINISTÉRIO DE MINAS E ENERGIA - MME. Brasília. Apresenta dados gerais sobre planejamento e matriz energética brasileira. Disponível em: $<$ http://www.mme.gov.br/>. Acesso em 15 de março de 2008.

MIRANDA, V.; PROENÇA, M. Probabilistic Choice vs. Risk Analysis - Conflicts and Synthesis in Power System Planning. IEEE Transaction on Power Systems, vol. 13, no 3, 1998a.

MOVIMENTO DOS ATINGIDOS POR BARRAGENS - MAB. São Paulo. Apresenta dados sobre histórico do setor elétrico brasileiro bem como impactos ambientais. Disponível em: <http://www.mabnacional.org.br/>. Acesso em 23 de fevereiro de 2008.

OPERADOR NACIONAL DO SISTEMA - ONS. Rio de Janeiro. Apresenta informações sobre a operação do Sistema Interligado Nacional - SIN. Disponível em: <http://www.ons.org.br/>. Acesso em 10 de março de 2008.

PAULA, G.M.F.; PAULA, G.M.F.; MAGALHÃES, C.H.N. de. Revisão Tarifária. Universidade de São Paulo. São Paulo, 2005. 
PÊGO, B.; CAMPOS NETO, C.A.S. O PAC e o Setor Elétrico: Desafios para o Abastecimento do Mercado Brasileiro (2007 - 2010). IPEA. Brasília, 2008.

RAMOS, D.S. Notas de aula da disciplina PEA 5771 - Formação de Preços e Comercialização de Energia no Novo Ambiente do Setor Elétrico. Universidade de São Paulo. São Paulo, 2005.

SILVA NETO, L.A. Derivativos: Definições, Emprego e Risco. São Paulo: Atlas, 3a ed., 2000.

SUSTERAS, G.L., RAMOS, D.S. Aplicação de Algoritmos Genéticos Para Previsão do Comportamento das Distribuidoras Como Apoio à Estratégia de Comercialização de Energia de Agentes Geradores. Universidade de São Paulo. São Paulo, 2006.

VEIGA, A. Avaliação de Carteiras de Contratos de Energia no MAE: Análise de Risco e Retorno. In: "A Nova Operação do Sistema Elétrico Brasileiro", 3a ed. DEE/CEE, PUC-Rio, 1999. 